\title{
SPECIFYING DUE PROCESS VALUES: TOWARD A MORE RESPONSIVE APPROACH TO PROGEDURAL PROTEGTION
}

\author{
RICHARD B. SAPHIRE $\dagger$
}

\section{INTRODUCTION}

Like most of the other significant constitutional provisions, the "due process of law" guarantees of both the fifth and fourteenth amendments to the United States Constitution were intended to express fundamental and deeply held values central to the framers' concept of government. ${ }^{1}$ Unlike those narrow, precise sections of the Constitution that the late Professor Bickel termed the "housekeeping provisions," 2 the principle of due process was meant to embody one of the "majestic concepts suited to a Constitution that was intended, in [Chief Justice John] Marshall's words, 'to endure for ages to come." " 3 To make the Constitution an organic charter, capable of retaining relevance and generating an ongoing sense of obligation throughout our evolution, required the use of language specific enough to be intelligible, yet general enough to allow for flexibility in interpretation. ${ }^{4}$

The very ambiguity of terms like "due process," and the "life, liberty and property" to which it expressly relates, while desirable

† Assistant Professor of Law, University of Dayton. B.A. 1967, Ohio State University; J.D. 1971, Northern Kentucky State College of Law; LL.M. 1975, Harvard University.

The author wishes to thank Mr. Jack Grove of the University of Dayton School of Law, Class of 1979, for his invaluable research assistance in the preparation of this Article.

1 See generally Kadish, Methodology and Criteria in Due Process AdjudicationA Survey and Criticism, 66 Yare L.J. 319 (1957). See also Grey, Do We Have an Unwritten Constitution?, 27 STAN. L. REv. 703 (1975).

2 A. Brckel, The Least Dangerous Branch 36 (1962) [hereinafter cited as Least Dangerous Branch].

${ }^{3}$ Id. 36-37. See also Braden, The Search for Objectivity in Constitutional Law, 57 YAIE L.J. 571 (1948).

4 The United States Supreme Court's opinions are replete with references to both the value and the tension inherent in the ambiguity of the constitutional language. See, e.g., Cafeteria \& Restaurant Workers Local 473 v. McElroy, 367 U.S. 886, 895 (1961); Wolf v. Colorado, 338 U.S. 25, 27 (1949). Cf. Appalachian Coals, Inc. v. United States, 288 U.S. 344, 359-60 (1933) (comparing the generality and adaptability of the language of the Sherman Antitrust Act, ch. 647, $\$ 1,26$ Stat. 209 (1890) (current version at 15 U.S.C. $\$ \$ 1-7$ (1976)), with that of constitutional provisions). See generally Note, Specifying the Procedures Required by Due Process: Toward Limits on the Use of Interest Balancing, 88 Harv. L. Rev. 1510, 1535-42 (1975) [hereinafter cited as Procedural Due Process]. 
for purposes of building play into the joints of the Constitution, tends to generate tensions with the other democratic values the Constitution was designed to symbolize and preserve. Having assumed the role of ultimate interpreter of the Constitution, ${ }^{5}$ the United States Supreme Court is frequently asked to invalidate or legitimate the acts and policies of the more political-and thus more popularly responsive-executive and legislative branches. Because of the Court's relative unresponsiveness to public influence and pressure, its exercise of the power of constitutional review has often been criticized as peculiarly suspect in a democracy. ${ }^{6}$ Accordingly, as in other areas of constitutional decisionmaking, the Court's attempts to define the content and scope of due process have been marked by a general cautiousness and gradualism born out of the obligation to preserve the meaningfulness of the constitutional restriction of governmental power while maintaining a concomitant regard for the legitimate power of the other branches and for its own delicate role in the constitutional scheme. ${ }^{7}$

This Article will address the Court's recent attempts to reconcile these tensions in the context of interpreting and applying the

5 Marbury v. Madison, 5 U.S. (1 Cranch) 137 (1803).

- The suspicion generally attached to the exercise of the Court's function in deciding the constitutionality of legislative, executive, and judicial conduct pervades the scholarly literature and the Court's own decisions. As to the former, compare, e.g., R. Berger, Government by Judxciary (1977); A. Bickel, The Supreme Court and the Idea of Progress (1970) [hereinafter cited as Inea of Progress]; Ely, The Wages of Crying Wolf: A Comment on Roe v. Wade, 82 Yare L.J. 920 (1973); Kurland, Toward a Political Supreme Court, 37 U. Crr. L. Rev. 19 (1969) with, e.g., Heymann \& Barzelay, The Forest and the Trees: Roe v. Wade and Its Critics, 53 B.U. L. Rev. 765 (1973); Rostow, The Democratic Character of Judicial Review, 66 Hanv. L. Rev. 193 (1952); Wright, Professor Bickel, the Scholarly Tradition, and the Supreme Court, 84 HARv. L. Rev. 769 (1971). See generally R. Dworkin, Takms Rights Seriously 131-49 (1977) [hereinafter cited as Taking Rughts SERIousty]. The Court's concern for the legitimacy of its power is frequently reflected in its opinions. See, e.g., Moore v. City of East Cleveland, 431 U.S. 494, $499-504$ (1977) (plurality opinion); Roe v. Wade, 410 U.S. 113, 152-56 (1973); Adamson v. California, 332 U.S. 46, 59-68 (1947) (Frankfurter, J., concurring); Palko v. Connecticut, 302 U.S. 319, 324-28 (1937).

It is noteworthy that even when the Court does not invalidate challenged governmental acts on constitutional grounds-that is, when it refuses to review cases within its obligatory or discretionary jurisdiction, when it disposes of cases upon procedural or prudential grounds, or even when it upholds the validity of the act in questionthe very existence of its power has often been the basis for criticism. See, e.g., Deutsch, Neutrality, Legitimacy, and the Supreme Court: Some Intersections Between Law and Political Science, 20 STAN. L. Rev. 169 (1968); Gunther, The Subtle Vices of the "Passive Virtues"-A Comment on Principle and Expediency in Judicial Review, 64 Colum. L. Rev. 1 (1964).

$\tau$ In the context of procedural due process, this deliberate approach was once described as "the gradual process of judicial inclusion and exclusion, as the cases presented for decision shall require." Davidson v. New Orleans, 96 U.S. 97, 104 (1877). 
due process clauses. ${ }^{8}$ Attention will be focused on the Court's efforts to discover articulable standards of due process in non-criminal, procedural contexts, especially those in which governmental action threatens to deprive an individual of an interest to which she claims a right or entitlement. Because inquiry will be centered on the processes of government-individual interaction, this Article will deal with the methodology of procedural, ${ }^{9}$ as opposed to substantive, ${ }^{10}$ due process. As will be noted, however, the dividing line between these two doctrines is often obscure. ${ }^{11}$

The thesis of this Article will be that the Supreme Court, in deciding when constitutional protections apply in non-criminal, adjudicative contexts, has generally failed to specify and articulate the values which underlie due process. Moreover, in those cases in which the Court has attempted to define due process values, it has generally done so in an ambiguous and unsatisfactory fashion. As a result, the formulation of due process standards, especially in recent years, has lacked the degree of symmetry, continuity, and principled content that we have come to expect in the development of constitutional law. Furthermore, by failing adequately to specify due process values, the Court has fashioned an approach to assessing the validity of governmental action that has essentially drained due process of its basic function as a limitation on the exercise of governmental power. The potential consequences of this development are extremely unsettling. The Court's current due process methodology has laid a foundation for a drastic restructuring of the

8 For purposes of this discussion, the due process clauses of both the fifth and fourteenth amendments will be treated as generally coextensive in scope. With some important exceptions, see, e.g., Mathews v. Diaz, 426 U.S. 67, 84-87 (1976) (due process restrictions on regulation of aliens), the applicability and scope of protection afforded under the two provisions have developed along parallel lines.

9 In its procedural aspect, due process has typically been viewed as setting the conditions, if any, which must attach to deprivatory governmental action. When operative, these conditions have normally been defined in terms of a requirement of some sort of notice and opportunity to be heard prior to adverse governmental action. See, e.g., Bell v. Burson, 402 U.S. 535, $541-42$ (1971); Goldberg v. Kelly, 397 U.S. 254, 267-69 (1970); Murray's Lessee v. Hoboken Land \& Improvement Co., 59 U.S. (18 How.) 272, 276-80 (1856). See generally Friendly, "Some Kind of Hearing," 123 U. PA. L. Rev. 1267 (1975); Procedural Due Process, supra note 4.

10 In its substantive aspect, due process has been viewed as imposing limitations on the occasions in which governmental action will be deemed valid at all. See, e.g., Moore v. City of East Cleveland, 431 U.S. 494 (1977); id. 542-44 (White, J., dissenting); Roe v. Wade, 410 U.S. 113 (1973); Lochner v. New York, 198 U.S. 45 (1905). See generally Dixon, The "New" Substantive Due Process and the Democratic Ethic: A Prolegomenon, 1976 B.Y.U. L. Rev. 43; McCloskey, Economic Due Process and the Supreme Court: An Exhumation and Reburial, 1962 Sur. Cr. Rev. 34.

11 See text accompanying notes 164-77 infra. See also Tushnet, The Newer Property: Suggestion for the Revival of Substantive Due Process, 1975 SUP. CT. REv. 261. 
basic relationship between government and the individual. More importantly, the Court's failure adequately to articulate and respond to due process values has contributed to an erosion of the conditions necessary for the generation of the political and legal obligation upon which a constitutional government depends.

In Section I of this Article, I will attempt to specify the values that I believe are central to due process. Sections II and III will discuss recent developments in the Court's attempts to articulate a theory of procedural due process, focusing on when due process protections become operative and analyzing the extent to which the current definition of due process is capable of responding to underlying constitutional values. In Section IV, I will suggest alternative approaches available to the Court which have greater potential for responsiveness to those values. Section $V$ will concentrate on the development of a model of procedural protection capable of minimal responsiveness to due process values. Finally, in Section VI, I will suggest reasons why the alternative methodologies developed in Section IV are consistent with generally accepted criteria for legitimacy in constitutional interpretation, and why they are readily reconcilable with the dilemmas inherent in the exercise of judicial power.

\section{Specifying Due Process Values: Substantive and} INHERENT DIGNITY

\section{A. Due Process as Fairness}

Due process has often been proclaimed to represent a constitutional concept of fairness. ${ }^{12}$ In its procedural context, the courts have often been less than specific in articulating. and defining the scope and composition of fairness as a constitutional value. For example, due process protections have been said to be essential to "restore faith that our society is run for the many, not the few, and that fair dealing rather than caprice will govern the affairs of men," 13 and to manifest "a profound attitude of fairness . . . compounded of history, reason, the past course of decisions, and stout

12 See, e.g., Cafeteria \& Restaurant Workers Local 473 v. McElroy, 367 U.S. 886, 899-902 (1961) (Brennan, J., dissenting); Joint Anti-Fascist Refugee Comm. v. McGrath, 341 U.S. 123, 161 (1951) (Frankfurter, J., concurring).

The equation of due process with fairness has not received unanimous judicial endorsement. See, e.g., Zurak v. Regan, 550 F.2d 86, 97 (2d Cir.) (van Graafeiland, J., dissenting in part), cert. denied, 433 U.S. 914 (1977). part).

${ }^{13}$ Morrissey v. Brewer, 408 U.S. 471, 499 (1972) (Douglas, J., dissenting in 
confidence in the strength of the democratic faith which we profess." 14 Elsewhere, due process has been described as a safeguard against "patently arbitrary or discriminatory" governmental action, ${ }^{15}$ and as a principle intended "to insure that [a] state-created right is not arbitrarily abrogated." 18 Although sweeping and colorful, these judicial attempts at articulating a meaningful constitutional standard leave much to be desired. They are more conclusory than explanatory. They fail to define a value capable of assuming an identity and content transcending the personal values of a judge. Moreover, their vagueness is likely to reduce the prospect that, with any acceptable degree of predictability, courts will identify those instances in which constitutional fairness is threatened and will take corrective action.

To be sure, generality in defining values can facilitate a degree of organic evolution which might be viewed as desirable. Moreover, such generality might enhance the likelihood that these values will become sufficiently pervasive in a society that they command adherence without the necessity of judicial intervention. ${ }^{17}$ But generality inevitably conflicts with the equally important dimension of "formal realizability," 18 which serves to promote predictability in determining the degree to which conduct comports with a given value. Such specificity limits both the discretion and the abuse to which vindication of a value might otherwise be subject. ${ }^{19}$ It is therefore important to develop an understanding of fairness which offers a more certain basis for determining why and when governmental conduct exceeds the constitutional limitation of due process.

14 Joint Anti-Fascist Refugee Comm. v. McGrath, 341 U.S. 123, 162-63 (1951) (Frankfurter, J., concurring).

15 Wieman v. Updegraff, 344 U.S. 183, 192 (1952). Accord, Dent v. West Virginia, 129 U.S. 114, 123-24 (1889).

16 Wolff v. McDonnell, 418 U.S. 539, 557 (1974).

In other contexts, the Court's attempts to define due process values have been equally vague. Thus, in deciding the extent to which the Bill of Rights is applicable to the states through the due process clause of the fourteenth amendment, it has been asked whether state criminal proceedings "offend those canons of decency and fairmess which express the notions of justice of English-speaking peoples." Adamson v. California, 332 U.S. 46, 67 (1947) (Frankfurter, J., concurring). See also Moore v. City of East Cleveland, 431 U.S. 494, 499-504 (1977) (plurality opinion); Duncan v. Louisiana, 391 U.S. 145, 147-58 (1968).

$17 \mathrm{Cf}$. Kennedy, Form and Substance in Private Law Adjudication, 89 Harv. L. Rev. 1685, 1689-90 (1976) (under a regime of general rules, everyone will know what those rules are).

$18 \mathrm{Id} .1687$.

$19 \mathrm{Id}$. 1687-88. For a more intensive discussion of the problems of form as related to achieving the goals of law, see Dworkin, The Model of Rules, 35 U. CEr. L. REv. 14 (1967) [hereinafter cited as Model of Rules]. 
One way to clarify the meaning of fairness might be to construct a mosaic based upon a series of past actions found to have been unfair. This ad hoc approach, however, has several drawbacks. ${ }^{20}$ First, it undermines the generally held view that values such as fairness must have some meaning that transcends the contexts in which they are applied. A purely piecemeal, incremental definition of fairness would be at odds with the view that fairness can or should have some guiding influence on the way in which persons or institutions should be expected to act. ${ }^{21}$ Second, this retrospective, ad hoc approach makes it extremely difficult rationally to assess conflicting claims concerning the fairness vel non of a given act or institution, because it is highly unlikely that acts will occur, or that institutions will function, in factually identical situations. ${ }^{22}$ Consequently, fairness cannot serve as a meaningful standard for evaluating the propriety of a given act, unless it is capable of articulation in terms that transcend any given act or condition. ${ }^{23}$

An alternative approach to developing a definition of fairness might be to equate it with other concepts commonly thought to embody the same general values. Accordingly, both courts and scholars have attempted to describe fairness in terms of justice. ${ }^{24}$ Although the difficulty of articulating a coherent theory of justice as

20 For more comprehensive analyses of the limitations of an ad hoc approach to constitutional decisionmaking, see, e.g., Deutsch, supra note 6, at 221-36; Frantz, Is the First Amendment Law?-A Reply to Professor Mendelson, 51 CaLTr. L. Rev. 729, 746-49 (1963); Note, The First Amendment Overbreadth Doctrine, 83 Harv. L. REv. 844, 849-50, 866-70 (1970).

21 It was this piecemeal perception of the nature of law which was at the core of American legal realism, and which ultimately became identified as hostile or antithetical to democratic notions of the rule of law. See generally E. PurcelL, TrIE Crisis of Democratic Theory (1973); W. Rumble, american legal Realism: Skepticism, Reforam and the Judictal Process (1968). See also Lusky, Minority Rights and the Public Interest, 52 YALE L.J. 1 (1942); Comment, Legal Theory and Legal Education, 79 YALE L.J. 1153 (1970).

22 Similar difficulties have been explored in the context of the application and enforcement of law generally through the judicial process. See, e.g., K. LLEwELLiN, The Bramble Bush (1968); Cohen, Transcendental Nonsense and the Functional Approach, 35 CoLum. L. Rev. 809 (1935); Model of Rules, supra note 19, at 22-29, $32-40$.

23 This proposition has often been advanced as a sine qua non for legitimacy in the process of substantive constitutional review. See, e.g., Wechsler, Toward Neutral Principles of Constitutional Law, 73 Harv. L. Rev. 1 (1959).

24 See, e.g., Adamson v. California, 332 U.S. 46, 67 (1947) (Frankfurter, J., concurring) (equating fairness with "notions of justice of English-speaking peoples"), quoted in relevant part at note 16 supra. See generally Michelman, In Pursuit of Constitutional Welfare Rights: One View of Rawls' Theory of Justice, $121 \mathrm{U}$. PA. L. REv. 962, 990-91 (1973) [hereinafter cited as Constitutional Welfare Rights]. See also J. RAwls, A THEORX OF Justxce (1971). 
fairness should not be underestimated, ${ }^{25}$ one could define as "fair" any governmental action that can be perceived as "just." Thus, if justice requires that citizens should not be subjected to taxation without representation, a tax levied without regard to popular consent would be unfair. Similarly, if justice requires that persons not be detained by the authorities without opportunity to be heard, summary incarceration would be unfair. ${ }^{28}$ Ultimately, of course, this process of hammering out the contours of justice succumbs to the same weaknesses inherent in an ad hoc approach to defining fairness. Like fairness, justice would require its own particularization in support of a coherent, rational theory. ${ }^{27}$

Because references to justice, or to other abstract concepts such as decency, ${ }^{28}$ tend to obscure a more particular definition of fairness, they are not of much practical use in our inquiry.

\section{B. Fairness as Dignity}

In order to articulate a standard of fairness appropriate for due process adjudication, I propose to define due process values in the context of what I believe to be one of the most important, although most frequently overlooked, consequences of governmental action: its impact upon the dignity of those individuals whom it adversely affects. This analysis is prompted by the view that, in the most fundamental sense, human beings are distinctive in the natural

25 See, e.g., J. RAwLs, supra note 24, at 3-53 (1971); Thibaut, Walker, La Tour \& Houlden, Procedural Justice as Fairness, 26 Stan. L. REv. 1271 (1974).

${ }^{26}$ Defining fairness in terms of justice can, of course, create more definitional problems than it solves. For instance, justice can be linked to substantive resultsthat is, distributive justice-so that its satisfaction may depend primarily upon the extent to which governments or institutions distribute society's goods and services to particular individuals or groups. See, e.g., Grey, Property and Need: The Welfare State and Theories of Distributive Justice, 28 STAN. L. Rev. 877 (1976).

On the other hand, justice may be viewed as more fundamentally concerned with the processes by which society's goods and services are allocated. See, e.g., Thibault, Walker, La Tour \& Houlden, supra note 25; Grey, Book Review, 25 STAN. L. REv. 286, 294 (1973). Unless we were to agree in advance upon which definition of justice (as fairness) we would apply to given acts or institutions, we would be likely to evaluate them quite differently. See R. UNGER, LAW IN MODERN SOCIETY 194-95 (1976). Consequently, the mere resort to a concept like justice as a method for narrowing or particularizing the concept of fairness can lead to an entirely new set of confusing definitional problems.

27 For an interesting discussion of the extent to which difficulties inherent in defining justice can tend to impede judicial reference to the requirements of justice in constitutional interpretation, see Constitutional Welfare Rights, supra note 24, at 1003-18. It is curious to note the lack of a similar concern in the judiciary's frequent references to the broad concept of fairness, even in a procedural context.

28 See, e.g., Adamson v. California, 332 U.S. 46, 61 (1947) (Frankfurter, J., concurring), in which Justice Frankfurter defined due process in terms of the need to protect "ultimate decency in a civilized society." 
order because of our capacity for reasoning, which allows us to develop moral and ethical values through which our experience is filtered and in the context of which our relations to each other, and to our milieu, are understood. Because the concept of personal dignity is basic to humanity, it can serve as a useful focus for our attempt to apply moral values, such as fairness, to our perception of the persons, institutions, and forces confronting us.

In this regard, it has been said that a fundamental feature of our moral lives, the existence of which distinguishes us from mere objects, is our capacity to experience "moral[ly] reactive attitudes," including indignation and resentment. ${ }^{29}$ Moreover, the idea of human dignity has been said to include "concern to achieve and maintain various forms of integrity, as well as attitudes of selfrespect, self-esteem, pride, shame, resentment, and indignation." 30 Viewed in terms of human dignity, fairness requires, at minimum, the preservation of conditions necessary to promote such concerns and attitudes. When governmental conduct threatens these conditions, it subverts the very basis for our distinctiveness as individuals. In this respect, governmental action that conflicts with or disregards fundamental notions of human dignity is morally unacceptable.

The nexus between fairness and human dignity has been noted in much of our political and moral philosophy, and has occasionally been viewed as central to constitutional interpretation. It was emphasized by John Locke, who noted that "freedom from absolute, arbitrary power is so necessary to, and closely joined with a man's preservation, that he cannot part with it but by what forfeits his preservation and life together." 31 Indeed, implicit in social contract theory is the view that the formation of formal societies and governments is prompted by a need, basic to all people, to preserve individual dignity and autonomy, both moral and physical. ${ }^{32}$ Fulfillment of this need is entrusted (or delegated) to government. This

29 P. Strawson, FreEdom and Resentment 17 (1974).

30 Pritchard, Human Dignity and Justice, 82 Ermcs 299, 300 (1972).

The concept of human dignity, although long a subject of philosophical inquiry and debate, has proved difficult to define. For several recent efforts to reach a satisfactory definition, see articles collected in 9 PrmLosopHY F. (1971).

31 J. Locke, An Essay Concerning the True Original, Extent, and End of Civil Government, in Two Treatises of Crvuc Governanent đf3, at 128 (Everyman's Library ed. 1953).

32 See J. RAwLs, supra note 24, at 536 (1971).

Recognition of dignity as a fundamental component of a fair or morally supportable political system is particularly evident in the work of Emmanuel Kant. In the second formulation of his categorical imperative, Kant inveighed against treatment of the individual as a means, instead of as an end in herself. The treatment 
general theme pervaded the political philosophy of Rousseau, Montesquieu, Kant, Grotius, and Pufendorf, profoundly influenced political thought in colonial America, and found its way into the philosophical foundation of the Constitution. ${ }^{33}$

\section{Substantive and Inherent Dignity}

In assessing the fairness (and thus the compliance with procedural due process) of deprivatory governmental conduct, this analysis requires a determination of the extent to which the conduct in question comports with basic notions of dignity. In this regard, it is useful to identify and separate what seem to be several distinct aspects of dignity. In important respects, dignity can be said to relate to substantive outcomes of governmental action. In this sense, unless all individuals have access to resources sufficient to enable them to satisfy essential physical needs, human life itself would be extinguished. Thus, if governmental action effected absolute deprivation of life-sustaining resources, such action would paradigmatically infringe upon human dignity and would be unfair. ${ }^{34}$ Moreover, even when absolute deprivation is not effected, basic notions of dignity might require that deprivatory action be premised upon the existence of facts or conditions that are generally believed to necessitate such action. In this situation, respect for human dignity would demand assurance that the facts upon which the action is based be determined by accurate and reliable means. ${ }^{35}$ Such assurance is basic to human dignity because it tends

of individuals as ends has been viewed as a necessary condition in order to generate feelings of dignity and self-respect. See Pincoffs, Due Process, Fraternity, and a Kantian Injunction, in DuE Process: Nomos XVIII 172 (J. Pennock \& J. Chapman eds. 1977).

33 B. BaIlyn, The Ineologtcal Origins of the American Revolution 27-30 (1967). See also Miller, The Forest of Due Process of Law: The American Constitutional Tradition, in DuE Process: Nomos XVIII 3 (J. Pennock \& J. Chapman eds. 1977).

34 In the equal protection context, this appears to be the general concept of fairness or justice at the core of Professor Michelman's "minimum protection." Michelman, Foreword: On Protecting the Poor Through the Fousteenth Amendment, 83 Harv. L. Rev. 7 (1969) [hereinafter cited as Foreword: On Protecting the Poor]. This approach has been rejected as inappropriate in a substantive due process context. See, e.g., Maher v. Roe, 432 U.S. 464, 469-70 \& n.5 (1977) (dictum) (no constitutional right to even life-sustaining health care).

35 Professor Michelman has recently described such assurances as the aim of what he calls "formal explanatory procedures." Michelman, Formal and Associational Aims in Procedural Due Process, in Dos Process: Nomos XVIII 126 (J. Pennock and J. Chapman eds. 1977) [hereinafter cited as Formal and Associational Aims]. He states that "[a] procedure is formal insofar as it focuses on the question of legal justification-and lays the agent's decision open to reversal by an arbiter or judge in case the agent can point to no true ground which justifies the 
to prevent arbitrary, callous, and perhaps preventable mistakes or omissions, toleration of which would reflect a view that the individual is unimportant, and that what really counts are values born out of expediency, convenience and ease of administration. ${ }^{36}$ Moreover, deprivatory governmental action based upon inaccurate or unreliable information frequently reflects a biased and indiscriminate use of official authority ${ }^{37}$ that is antithetical to the whole concept of the rule of law. ${ }^{38}$

It is crucial to recognize that both aspects of human dignity just discussed relate directly to the substantive outcomes of governmental action..$^{39}$ However, there is another aspect of human dignity that seems essential to the ideal of fairness, and which has been viewed as central to western liberal political thought. This is the sense of dignity that springs, not from the outcomes of governmental decisions and conduct, but from the interaction between in-

action under some legally valid precept." Id. 126-27 (footnote omitted). See also Mashaw, The Management Side of Due Process: Some Theoretical and Litigation Notes on the Assurance of Accuracy, Faimess, and Timeliness in the Adjudication of Social Welfare Claims, 59 CoRNELL L. REv. 772, 774-75 (1974) [hereinafter cited as Management Side of Due Process] ("Accuracy is . . the substantive ideal ...." "Fairness" is the degree to which the process of making claims determinations tends to produce accurate decisions.").

It is this sense of dignity that appears to have drawn the Court's exclusive attention in recent cases. See, e.g., Dixon v. Love, 431 U.S. 105 (1977) (rejecting individual's claim of right to prior hearing for revocation of driver's license when revocation is based upon statutorily-set number of previous convictions, all of which were based on evidentiary hearings); Codd v. Velger, 429 U.S. 624 (1977) (rejecting policeman's due process claim that the placement of stigmatizing material in his personnel file entitled him to a hearing prior to his dismissal because he had not alleged that the government's characterization of him was false).

${ }^{36}$ The Supreme Court has long recognized that due process, where applicable, requires at least minimal procedural assurances that deprivatory governmental action is based upon accurate and reliable information. See, e.g., Morrissey v. Brewer, 408 U.S. 47I, 484 (1972); Green v. McElroy, 360 U.S. 474, 496 (1959). See generally Friendly, supra note 9; Rubenstein, Procedural Due Process and the Limits of the Adversary System, I1 HARv. C.R.-C.L. L. Rev. 48 (1976).

37 See, e.g., Morrissey v. Brewer, 408 U.S. 471, 486 (1972); cf. Tumey v. Ohio, 273 U.S. 510 (1927) (a system in which an inferior judge is paid for his services only if he convicts the defendant violates due process). See generally O'Neil, Of Justice Delayed and Justice Denied: The Welfare Prior Hearing Cases, 1970 Sup. CT. Rev. 161, 183.

38 R. UNGER, supra note 26 , at 192-200.

39 In the first example, it is the result itself (absolute deprivation of access to resources) that is perceived to be unfair. The second aspect of dignity, illustrated by the example in which governmental deprivatory action is premised upon inaccurate or unreliable factual information, is also "outcome-oriented." The results of decisions based upon such information will necessarily be perceived as unfair in that no one will know what outcome the government might have achieved had it acted upon complete and reliable information. Thus, even when the defect lies in the means, or process, which the government uses to gather information, it is the outcome itself, rather than merely the process by which it is generated, that is perceived to be arbitrary, and thus unfair. 
dividuals and their government that occurs as part of the decisionmaking process. This aspect of dignity, which will be referred to here as "inherent dignity" (because it is inherent in the process by which decisions are reached and conduct is affected, yet it is independent of extrinsic, substantive outcomes), ${ }^{40}$ has only occasionally been alluded to in the Supreme Court's attempts to articulate the purpose and function of due process. Perhaps the most eloquent reference to it can be found in Justice Frankfurter's concurring opinion in Joint Anti-Fascist Refugee Committee v. McGrath, ${ }^{41}$ in which he wrote:

No better instrument has been devised for arriving at truth than to give a person in jeopardy of serious loss notice of the case against him and opportunity to meet it. Nor has a better way been found for generating the feeling, so important to a popular government, that justice has been done. ${ }^{42}$

More recently, Justice Stevens expressed the view that this aspect of dignity was perhaps the most fundamental of all values, and that it was immutably anchored in the liberty protected by the fourteenth amendment's due process clause. ${ }^{43}$

In other recent cases, some of the Justices have recognized the need for procedures that promote inherent dignitary values, but they have not made this concept decisive in their due process analyses. For example, in concluding that due process attached to parole revocation, the Court in Morrissey v. Brewer"44 noted that "fair

40 Throughout this Article, I will refer to "inherent dignitary values." As the ensuing discussion will illustrate, these are values inherent in process, unrelated to substantive outcomes, and which, when observed, tend to bolster the affected individual's sense of integrity, self-respect, and autonomy. In using this novel term, I am aware that $I$ am bending the normal confines of language to encompass new thoughts.

41341 U.S. 123, 149 (1951) (Frankfurter, J., concurring).

42 Id. 171-72 (emphasis added).

43 Meachum v. Fano, 427 U.S. 215, 233 (1976) (Stevens, J., dissenting). In arguing that a state prisoner had a due process right to notice and opportunity to be heard prior to being transferred to a more restrictive prison, Mr. Justice Stevens, whose opinion was joined by Justices Marshall and Brennan, stated:

For if the inmate's protected liberty interests are no greater than the State chooses to allow, he is really little more than the slave described in the 19th century cases. I think it clear that even the inmate retains an unalienable interest in liberty-at the very minimum the right to be treated with dignity - which the Constitution may never ignore.

Id. 233 (emphasis added). For further discussion of Meachum as it pertains to the development of procedural due process methodology, see text accompanying notes 111-20 infra.

44408 U.S. 471 (1972). 
treatment in parole revocations will enhance the chance of rehabilitation by avoiding reactions to arbitrariness." 45 Similarly, in Wolff $v$. McDonnell, , $^{40}$ Justice Marshall, urging the recognition of broad-based due process protections for prisoners subjected to disciplinary proceedings, partially based his argument upon the importance of preempting the sense of unfairness inevitably created by unrestrained governmental action. ${ }^{47}$ It is noteworthy that references to the importance of a subjective perception of fairness have tended to be relatively oblique, ${ }^{48}$ and that the Court has often either ignored this value completely or, on at least one occasion, expressly discounted it as unimportant to its analysis. ${ }^{49}$

Concern for inherent dignitary values in procedural due process methodology has recently emerged in the scholarly literature..$^{50}$ These values have been referred to and described in various ways, including: "the value of autonomy, of controlling the events that affect you .... and the respect and self-respect that come with it"; ${ }^{\text {s1 }}$

45 Id. 484.

46418 U.S. 539 (1974).

47 Id. 588-89 (Marshall, J., concurring in part and dissenting in part;.

48 See, e.g., Goss v. Lopez, 419 U.S. $565,583-84$ (1975) (due process operative in public-school suspensions because of the value in "at least an informal giveand-take between student and disciplinarian").

More recently, the Court has held that failure to accord procedural due process protection, where otherwise applicable, gives rise to a damage action under the Civil Rights Act of 1871,42 U.S.C. $\$ 1983$ (1976). Compensatory damages, where objectively proved, may include recovery for mental and emotional distress associated with the denial of the "feeling of just treatment." Carey v. Piphus, 435 U.S. 247, 261, 260-64 (1978) (quoting Joint Anti-Fascist Refugee Comm. v. McGrath, 341 U.S. 123, 162 (1951) (Frankfurter, J., concurring)).

49 See Dixon v. Love, 431 U.S. 105 (1977), in which the Court rejected the claim of an individual whose driver's license had been revoked that a pre-revocation hearing, in the circumstances of his case, was necessary so that he could at least appeal to the Mllinois Secretary of State for leniency or for a departure from the Secretary's own regulations. The Court stated that "[s]uch an appearance might make the licensee feel that he has received more personal attention, but it would not serve to protect any substantive rights." Id. II4.

It seems curious that the Court would place significant emphasis on its concern for the "feelings" of the parolee in Morrissey v. Brewer, 408 U.S. 471 (1972), but would view the effect of the license revocation on Mr. Love's "feelings" as constitutionally irrelevant. Moreover, Justices Stevens and Marshall, who vigorously dissented in Meachum v. Fano, 427 U.S. 215 (1976), because of the Court's nonrecognition of a due process "right to be treated with dignity," $i d .233$ (Stevens, J., dissenting); note 43 supra, apparently viewed such a right as inoperative in Love, because they concurred in the Court's opinion. 431 U.S. at 116. Justice Brennan, another dissenter in Meachum, concurred in the result in Love. Id. 117.

50 For an earlier discussion of the role of dignitary values in the due process formula, see Kadish, supra note 1 , at 347 .

51 Dauer \& Gilhool, The Economics of Constitutionalized Repossession: A Critique for Professor Johnson, and a Partial Reply, 47 S. CaL. REv. 116, 148-49 (1973). 
"process values," described in terms of "[h]umaneness and [r]espect for [i]ndividual [d]ignity"; ${ }^{52}$ as the opportunity for "revelation and participation," "s and as "intrinsic" values, representing "a valued human interaction in which the affected person experiences at least the satisfaction of participating in the decision that vitally concerns her, and perhaps the separate satisfaction of receiving an explanation of why the decision is being made in a certain way." 54

However defined, the concept of dignity now under consideration is marked by at least two closely related characteristics. First,

52 Summers, Evaluating and Improving Legal Processes-A Plea for "Process Values," 60 Connell L. Rev. 1, 23 (1974). See also Subrin \& Dykstra, Notice and the Right to be Heard: The Significance of Old Friends, 9 HARv. C.R.-C.L. L. REv. 449 (1974).

53 Formal and Associational Aims, supra note 35, at 127 (emphasis omitted). In his provocative article, Professor Michelman addresses the nature and interrelationship of "nonformal" and "formal," or "associational," aims, which he contends "explanatory procedures of the type broadly connoted by 'due process' can serve." Id. 128. These aims apparently can be associated with formal and nonformal values. The formal values appear to be related to substantive criteria, which Professor Michelman describes in terms of "possessive, privatistic aims," id., while the informal values are identified with "a communal or fraternal aspect of social life of which a purely formal view ... may remain oblivious." Id. Although this approach may be technically distinct from my reference to an overall value of human dignity reduced to substantive and inherent elements, our focus on separating out from due process analysis a specific concern for autonomy and humanity appears to be the same. This also applies to Subrin and Dykstra's discussion of the "'arriving at truth" "and "human dignity" functions of due process. Subrin \& Dykstra, supra note 52, at 452 (quoting Joint Anti-Fascist Refugee Comm. v. McGrath, 341 U.S. 123, 171 (1951) (Frankfurter, J., concurring)).

In this regard, my placing both substantive and inherent concerns within the general ambit of a dignitary value serves to emphasize my view that at the core of due process lies an elementary concern for the morality of governmental action, defined in terms of the obligation to maintain a democratic community committed to the ultimate integrity of each person qua individual. This approach presupposes a recognition that substantive and inherent values are ultimately and inexorably interrelated, a view also endorsed by Professor Michelman. Formal and Associational Aims, supra note 35 , at 131 .

For a general argument supporting a due process "right to participate" in the context of administrative rulemaking, see Sinaiko, Due Process Rights of Participation in Administrative Rulemaking, 63 CAL. L. REv. 886, 887 (1975).

54 L. Trmae, American Constitutional Law 502-03 (1978) [hereinafter cited as ANIERTCAN Constitutional LAw]. See generally id. 501-06.

Professor Tribe has elsewhere noted the importance of the values under discussion when he questioned the legitimacy of "[r]ule-of-thumb disposition of human liberty" in certain contexts because such treatment is "intrinsically unjust in that it denies the individual a responsive explanation of the exercise of state authority over her." Tribe, Structural Due Process, 10 Harv. C.R.-C.L. L. Rev. 269, 306-07 (1975).

Professor Dworkin has recently described this value as "the vague but powerful idea of human dignity," an idea "associated with Kant, but defended by philosophers of different schools," which "supposes that there are ways of treating a man that are inconsistent with recognizing him as a full member of the human community, and holds that such treatment is profoundly unjust." TAkNv RugETs SEIrousLy, supra note 6 , at 198. 
it reflects a view that fairness in government-individual relations can never be defined solely in terms of outcomes, nor even in terms of the fact-producing mechanisms upon which those outcomes depend; rather, the processes of interaction themselves are always important in their own right. ${ }^{55}$ In this respect, regardless of how satisfied any individual is with her share of government largess, or with private rights received or retained, none of her interactions with government will generate the feeling of fairness, and thus be perceived as fair unless the process of interaction at least minimally attends to commonly held values of individual autonomy, integrity, and self-respect. ${ }^{56}$ Secondly, this concept of dignity reflects a view that individual perceptions and feelings about governmental processes are to be taken into account in assessing their legitimacy. ${ }^{57}$ In a basic sense, these propositions represent the crucial distinctions between democratic and totalitarian or authoritarian political systems, and are at least implict in contemporary western criticism of the Soviet system. ${ }^{58}$ They also suggest that even when outcomes of decisions are viewed as unfair or unjust, the decisions may be accepted as legitimate if the processes through which they are reached respond to basic principles of self-respect and autonomy. ${ }^{50}$ In the

55 In this regard, Professor Tribe's observations are instructive: "In most areas of human endeavor-from performing a symphony to orchestrating a society-the processes and rules that constitute the enterprise and define the roles played by its participants matter quite apart from any identifiable 'end state' that is ultimately produced." Tribe, Technology Assessment and the Fourth Discontinuity: The Limits of Instrumental Rationality, 46 S. CAL. L. REv. 617, 631 (1973).

56 It is important to note that the converse of this proposition is also true. Just as substantive values are necessary but insufficient to account for justice or fairness, procedurally-based, inherent values cannot, by themselves, be enough. As John Rawls has noted:

Clearly we cannot say that a particular state of affairs is just because it could have been reached by following a fair procedure. This would permit far too much and would lead to absurdly unjust consequences. It would allow one to say that almost any distribution of goods is just, or fair, since it could have come about as a result of fair gambles.

J. Rawls, supra note 24 , at 86.

57 "By asking to hear from litigants and listening to them, the 'system' is treating them with a dignity consonant with their self-image as human beings; each is important, and each has some measure of control over his own destiny." Subrin \& Dykstra, supra note 52 , at 457 .

58 See, e.g., Shaughnessy v. United States ex rel. Mezei, 345 U.S. 206, 224 (1953) (Jackson, J., dissenting): "Severe substantive laws can be endured if they are fairly and impartially applied. Indeed, if put to the choice, one might well prefer to live under Soviet substantive law applied in good faith by our commonlaw procedures than under our substantive law enforced by Soviet procedural practices."

69 Although I have been unable to discover empirical support for this view, my past experience in representing the poor has repeatedly shown that tenants, consumers, and welfare recipients often regard the way in which they are treated by 
final analysis, the extent to which any society accounts for and attends to these aspects of inherent dignity reveals whether humanity itself is an operative value..$^{60}$

This Article will next address recent developments in the application of procedural due process. In particular, it will focus attention on the analytic framework which the Supreme Court uses to determine whether and when the due process guarantee applies to interaction between government and individuals. ${ }^{61}$ It will then be possible to determine the extent to which the Court's current approach responds to the values of autonomy, self-respect, and dignity.

\section{Recent Evolution of Due Process Methodology: Board of Regents $v$. Roth ${ }^{62}$ AND ITS PROGENY}

\section{A. The Traditional Approaches}

The requirements of notice and an opportunity to be heard have long been viewed as lying at the core of the due process command. ${ }^{63}$ This proposition alone, however, does little to clarify the practical significance of due process protection in contemporary American jurisprudence. Aside from the problem of determining what such protection will look like in the myriad contexts in which it will be invoked, ${ }^{04}$ the threshold question of when any procedural safeguard becomes operative must be addressed.

Although due process has not always been held to require the imposition of procedural safeguards whenever governmental actions adversely affect individual interests, ${ }^{65}$ it has been viewed until recently as imposing some form of procedural buffer through which

governmental institutions at least as importantly as the extent to which they achieve their substantive goals. These process-related concerns are central to issues of the quality of obligation and nature of consent that a morally supportable government must command, and are further explored at text accompanying notes 334-50 infra.

$60 \mathrm{See}, \mathrm{R}$. UNGER, supra note 26, at 205-09.

61 Having concluded that due process applies, the Court next turns its attention to a determination of "what process is due." See, e.g., Ingraham v. Wright, 430 U.S. 651, 674-82 (1977) (holding that common law remedies provide adequate protection from excessive corporal punishment in schools); Wolff v. McDonnell, 418 U.S. 539, 558-72 (1974). See generally AMERrcan Constrtutional Law, supra note 54, at 532-56; Procedural Due Process, supra note 4, at 1510.

62408 U.S. 564 (1972).

e3 See, e.g., McVeigh v. United States, 78 U.S. (11 Wall.) 259, 267 (1870).

64 See generally Friendly, supra note 9, at 1279-95.

65 See Board of Regents v. Roth, 408 U.S. 564, 570-71 \& n.7 (1972). The Court has repeatedly noted that due process protections need not apply where a given deprivation is de minimis. See, e.g., Ingraham v. Wright, 430 U.S. 651, 674 (1977). 
governmental action must pass before significant deprivation of a protected interest may be effected. During recent years, the Court has paid special attention to defining the interests that must be affected before mandatory procedural safeguards are triggered. ${ }^{68}$ The result has been a radical transformation in due process methodology, with startling and profound implications for the extent to which we can expect underlying due process values to be preserved.

Although the fifth and fourteenth amendments inveigh against governmental deprivation of "life, liberty or property, without due process of law," concern for independent definitions of liberty and property as a threshold issue to trigger procedural protection in non-criminal settings is a recent phenomenon. Instead, the relevant inquiry usually centered on an evaluation of the seriousness of the injury to some individual interest that was threatened by the governmental action in question.

Prior to Goldberg $v$. Kelly, ${ }^{67}$ the Court often directed its inquiry toward determining whether the threatened interest was a "right" or a "privilege." When the interest was held to be merely a privilege, constitutional protection was much less likely to be accorded.6s In Goldberg, the Court expressly rejected this distinction, ${ }^{69}$ and instead focused its inquiry upon an evaluation of the severity of the injury to some individual interest. When the potential injury was viewed as sufficiently serious, new or additional procedural safeguards would be required. ${ }^{70}$ This analysis included

${ }^{66}$ In determining whether the procedural safeguards of the Bill of Rights apply to state criminal proceedings through the fourteenth amendment, the Supreme Court has long focused on defining the liberty expressly protected by that amendment's due process clause. See, e.g., Duncan v. Louisiana, 391 U.S. 145 (1968). A similar definition of liberty has been central to the Court's identification of the substantive aspects of due process protection. See, e.g., Carey v. Population Serv. Int'l, 431 U.S. 678 (1977); Roe v. Wade, 410 U.S. 113 (1973).

67397 U.S. 254 (1970).

68 See generally Van Alstyme, The Demise of the Right-Privilege Distinction in Constitutional Law, 81 HARv. L. Rev. 1439 (1968) [hereinafter cited as Demise of Right-Privilege Distinction].

69397 U.S. at $262 \&$ n.8.

It has been persuasively contended that recent Supreme Court decisions, see, e.g., Bishop v. Wood, 426 U.S. 341 (1976); Arnett v. Kennedy, 416 U.S. 134 (1974) (plurality opinion), have effectively resurrected the right-privilege dichotomy. Bishop v. Wood, 426 U.S. at 353 n.4 (Brennan, J., dissenting). See also Van Alstyne, Cracks in "The New Property": Adjudicative Due Process in the Administrative State, 62 CoRNELL L. REv. 445 (1977) [hereinafter cited as Cracks in "The New Property"]; Comment, Entitlement, Enjoyment, and Due Process of Law, 1974 DUKE L.J. 89, 98-99.

70 This inquiry was often described in terms of whether the individual subjected to deprivatory government action was "condemned to suffer grievous loss." Goldberg v. Kelly, 397 U.S. 254, 263 (1970) (quoting Joint Anti-Fascist Refugee Comm. v. 
an attempt to assess and balance the severity of the threatened deprivation against the burden that new or additional safeguards would impose on the governmental function in question. ${ }^{71}$ But even before Goldberg, while the right-privilege dichotomy was still in vogue, the Court's approach did not depend upon a further or parallel inquiry into whether the target of the governmental act was a liberty or property interest. Indeed, it was apparently assumed that even governmental benefits and entitlements constituted interests at least potentially deserving of due process protection. $^{72}$ In a 1972 case, however, the Court announced its departure from this approach.

\section{B. Board of Regents v. Roth: The Development of a New Methodology}

The Court first announced a change in procedural due process methodology in Board of Regents $v$. Roth, ${ }^{73}$ in which Mr. Justice Stewart stated for the Court: ${ }^{74}$

The requirements of procedural due process apply only to the deprivation of interests encompassed by the Fourteenth Amendment's protection of liberty and property. ... .

The District Court decided that procedural due process guarantees apply in this case by assessing and balancing the weights of the particular interests involved. . . B But, to determine whether due process requirements apply in the first place, we must look not to the "weight" but to the nature of the interest at stake. . . . We must look to see if the interest is within the Fourteenth Amendment's protection of liberty and property. ${ }^{75}$

McGrath, 341 U.S. 123, 168 (1951) (Frankfurter, J., concurring)). See also Bell v. Burson, 402 U.S. 535 (1971); Sniadach v. Family Fin. Corp., 395 U.S. 337 (1969).

71 See Goldberg v. Kelly, 397 U.S. 254, 262-63, 267 (1970) ("The extent to which procedural due process must be afforded the [welfare] recipient . . . depends upon whether the recipient's interest in avoiding that loss outweighs the governmental interest in summary adjudication."). See generally Monaghan, Of "Liberty" and "Property," 62 Connell L. Rev. 405, 407-08 (1977).

72 See generally Comment, Due Process and Public Employment in Perspective: Arbitrary Dismissals of Non-Civil Service Employees, 19 U.C.L.A. L. Rev. 1052, 1059-62 (1972).

73408 U.S. 564 (1972).

74 Mr. Justice Brennan filed a dissenting opinion, in which Mr. Justice Douglas joined, id. 604. Mr. Justice Marshall filed a separate dissenting opinion, id. 587, as did Mr. Justice Douglas, id. 579. Mr. Justice Powell took no part in the decision. 75 408 U.S. at 569-71 (emphasis in original) (footnotes and citations omitted). 
Although the Court had previously noted the relevance of the "nature" of the individual's interest in determining what process was due, ${ }^{76}$ the above-quoted language indicated an intent to make the "nature" of the interest affected by governmental action determinative in deciding whether due process applied at all.77 In Roth, the Court held that a non-tenured assistant professor at a Wisconsin state university, who was in good standing and who had not been formally advised of any official dissatisfaction with the performance of his duties, had no due process right to notice and a hearing prior to the university's refusal to renew his one-year probationary contract. ${ }^{78}$ The Court rejected Roth's contentions that the interest in his repu-

76 See, e.g., Fuentes v. Shevin, 407 U.S. 67, 89-90 (1972), in which the Court refused to focus on the weight of the individual's interest in retaining certain goods subject to pre-judgment replevin; instead, the Court's inquiry was directed toward the "type" of interest affected.

77 For a general discussion of the role of interest balancing in due process adjudication both before and after Roth, see Procedural Due Process, supra note 4.

Although the Court continues in theory to reject the legitimacy of interest balancing until it has concluded that due process applies, there remains some evidence that it has not always done so in practice. Thus, while references to the Roth language quoted in text accompanying note 75 supra are now standard, see, e.g., Meachum v. Fano, 427 U.S. 215, 224 (1976), the outcomes of the cases could also be viewed as consistent with pre-Roth analysis. In this regard, the Court, in Mathews v. Eldridge, 424 U.S. 319 (1976), held that social security disability benefits are properly entitled to due process protection; despite strong precedent to the contrary, however, it also held that recipients are not entitled to a hearing prior to benefit termination. In applying its interest balancing test to determine what process was due, the Court took a restrictive view of the extent to which recipients were actually disadvantaged by the termination of benefits. In analyzing the nature of the injury sustained by the recipient, the Court also deemphasized the broader societal interest in the assurance that eligible beneficiaries continue to receive assistance until factual conditions clearly establishing ineligibility are adequately proven-an element of inquiry held essential in Goldberg v. Kelly, 397 U.S. 254, 261, 266 (1970). It is at least arguable that the Court, sub rosa, engaged in some interest balancing prior to concluding that Eldridge was entitled to less protection than his Aid to Families with Dependent Children counterpart in Goldberg. To the extent that pre-deprivation hearings provide greater protection from governmental mistake and arbitrariness than do post-deprivation ones, see, e.g., Ingraham v. Wright, 430 U.S. 651, 701 (1977) (Stevens, J., dissenting), it can be argued that the Court viewed disability benefits as a less important type of property (i.e., more like a privilege) than other types still entitled to pre-deprivation hearings. Compare Goss v. Lopez, 419 U.S. 565 (1975) (holding that public school students have liberty and property interests in continued education, and that they cannot be deprived of these interests, through suspension, until they have been accorded a due process hearing). This view would parallel and reinforce the apparent resurrection of the right-privilege dichotomy in other due process cases. See note 69 supra.

78 For more detailed description and analysis of the factual background and the Court's treatment of the due process issue in Roth, see Formal and Associational Aims, supra note 35. See also Grey, Procedural Fairness and Substantive Rights, in Due Process: Nomos XVIII 182, 187-92 (J. Pennock \& J. Chapman eds. 1977); Cracks in "The New Property," supra note 69, at 457-60. 
tation was in the nature of a liberty interest protected by the fourteenth amendment. ${ }^{79}$

Moreover, in rejecting Roth's claim that he had a constitutionally protected property interest in continued employment, the Court said:

These interests-property interests-may take many forms.

... To have a property interest in a benefit, a person clearly must have more than an abstract need or desire for it. He must have more than a unilateral expectation of it. He must, instead, have a legitimate claim of entitlement to it. ...

Property interests, of course, are not created by the Constitution. Rather, they are created and their dimensions are defined by existing rules or understandings that stem from an independent source such as state law-rules or understandings that secure certain benefits and that support claims of entitlement to those benefits. ${ }^{80}$

After concluding that there were no provisions in state statutory or common law that could be construed to give Roth an expectation that his employment contract would be renewed at the end of its one-year term, the Court held that Roth had no "legitimate claim of entitlement" to reemployment, and therefore had no property interest sufficient to trigger due process protection. ${ }^{81}$

79 The Court stated that "there is no suggestion that the State, in declining to re-employ the respondent, imposed on him a stigma or other disability that foreclosed his freedom to take advantage of other employment opportunities." 408 U.S. at 573. Although the Court indicated that the existence of reputational injury would have made it "a different case," $i d$. 574, subsequent developments have raised doubt concerning that prospect. See, e.g., Paul v. Davis, 424 U.S. 693 (1976) (holding that damage to reputation by itself does not state a cause of action under the due process clause), discussed in text accompanying notes 153-62 infra.

80 Board of Regents v. Roth, 408 U.S. 564, 576-77 (1972).

81 In Roth's companion case, Perry v. Sindermann, 408 U.S. 593 (1972), the Court gave some further hints concerning what conditions would create a legitimate claim of entitlement to continued employment in the public sector. In that case, plaintiff Sindermann alleged that he had been employed as a teacher in the Texas state college system for ten years before his summary discharge; and that even though he had no formal guarantee of tenure, the college had an informal, de facto tenure system. The Court held that if these facts could be proved on remand, they would establish Sindermann's protectable property interest in continuing employment. But see Bishop v. Wood, 426 U.S. 341 (1976) (upholding the summary discharge of a non-probationary police officer). For a general discussion of the implications of Roth, Sindermann, and Wood for the due process rights of public employees, see Rabin, Job Security and Due Process: Monitoring Administrative Discretion Through a Reasons Requirement, 44 U. CEu. L. Rev. 60 (1976). 
The implications of Roth have become clearer in the Court's subsequent procedural due process cases. ${ }^{82}$ In Arnett $v$. Kennedy, ${ }^{83}$ Justice Rehnquist, writing for a plurality of the Court, concluded that positive law must be the touchstone for determining whether an interest infringed by governmental action is in the nature of a property interest entitled to constitutional protection. Moreover, he concluded that when property interests are created by positive law, such as state or federal statutes, they are also defined and limited by the law which creates them, and not by the Constitution. Thus, when the legislature expressly attaches procedural protections to statutory entitlements, those protections become part of the substantive interest created; unless express provision to the contrary is made, they will be viewed as qualifying or limiting that interest. ${ }^{84}$

82 Although the Court's reasons for shifting the threshold question of the applicability of due process from an analysis of the "weight" of the individual interest involved to the "nature" of that interest remain unclear, several possible motivations are identifiable. First, although the Court has indicated that the constitutional concepts of liberty and property are "broad and majestic," Board of Regents v. Roth, 408 U.S. 564,571 (1972), it has also cautioned that they are not without limitations. Id. 572. Although the Court has recognized its obligation to define the contours of liberty and property with flexibility in order to give them a meaningfully broad scope, see, e.g., Moore v. City of East Cleveland, 43I U.S. 494, 501-02 (1977) (plurality opinion), it has also become increasingly sensitive to the proliferation of litigation raising issues of procedural due process, see, e.g., Paul v. Davis, 424 U.S. 693, 698-99 (1976), and the threat to the integrity of governmental programs and processes posed by the continued institutionalization and formalization of constitutional procedures in administrative proceedings generally. See, e.g., Ingraham v. Wright, 430 U.S. 651, 680-82 (1977).

Secondly, the Supreme Court's efforts to expand the scope of individual rights and interests under the due process clauses have raised serious concerns about its appropriate role in the constitutional scheme. According to this view, the Court must always resolve problems of anti-majoritarianism with an eye toward the constitutionally and prudentially mandated requirement of restraint. See, e.g., Smith v. Organization of Foster Families for Equality \& Reform, 431 U.S. 816, 855-56 (1977); Moore v. City of East Cleveland, 431 U.S. 494, 530 (1977) (Burger, C.J., dissenting). See also text accompanying notes 296-321 infra.

Neither of these possible explanations of the Court's shift from a "weight" to a "nature" of the interest analysis mitigates the obvious problems created by the Court's new approach. Although the new analysis is as conducive as the old to determining the applicability of due process, it is also fraught with the same problems. See note 77 supra. It is somewhat difficult to understand how interest balancing becomes less subjective when invoked after an interest is held to be protected than before. Moreover, even though some due process claims rejected under a "nature" analysis might have been recognized under a "weight-of-the-interest" approach, see, e.g., Montanye v. Haymes, 427 U.S. 236 (1976) (prisoners have no due process right to remain in a particular penal facility, even when a transfer may have a "substantial[ly] adverse impact on the prisoner." Id. 242), the Court has thus far failed to explain adequately why its new approach is less susceptible to judicial abuse than the old one.

83416 U.S. 134 (1974).

84 Mr. Justice Rehnquist stated: “The employee's statutorily defined right is not a guarantee against removal without cause in the abstract, but such a guarantee as enforced by the procedures which Congress has designated for the determination 
This analysis, which was rejected by six Justices in Arnett, ${ }^{85}$ appears to make the applicability of due process safeguards depend upon the legislature's willingness to write protective procedures into the statute. Regardless of how limited they are, unless such procedures were determined to be independently violative of other substantive constitutional rights, ${ }^{86}$ they would be, under this approach, the only operative safeguards against official arbitrariness. This conclusion would apparently apply even when the effect of the deprivatory action drove the individual "to the wall,"st or otherwise caused him to suffer "grievous loss." 88 Moreover, where the legislature failed to include any procedural safeguards in the statutory scheme, the due process clauses would not impose them. ${ }^{89}$ In short, the ap-

of cause." Id. 152 (plurality opinion). For a comprehensive analysis and critique of Arnett, see Comment, Fear of Firing: Arnett v. Kennedy and the Protection of Federal Career Employees, 10 Harv. C.R.-C.L. L. Rev. 472 (1975). See also Cracks in "The New Property," supra note 69, at 460-66.

It should be noted that this reasoning can work both ways. The legislature could expressly attach procedural protections that are greater than those that would have been constitutionally required under prior case law. Such protections would have been valid, however, even before the advent of Mr. Justice Rehnquist's "whole package" approach.

S6 Mr. Justice Powell, joined by Mr. Justice Blackmun, wrote an opinion concurring in part and concurring in the result in part (that is, rejecting Arnett's due process claim), but also expressly rejected the plurality's analysis. 416 U.S. at 164, 166-67 (Powell, J., concurring in part and concurring in the result in part). Mr. Justice White, writing for himself, concurred in part and dissented in part; he also expressly rejected the plurality's approach. Id. 171, 177-81 (White, J., concurring in part and dissenting in part). Mr. Justice Douglas dissent, id. 203 (Douglas, J., dissenting), as well as the dissenting opinion of Mr. Justice Marshall, in which Justices Douglas and Brennan joined, also rejected the plurality's analysis. Id. 206 (Marshall, J., dissenting).

${ }^{86}$ See, e.g., Mt. Healthy City School Dist. v. Doyle, 429 U.S. 274, 283-84 (1977) (Even though a school board may discharge an untenured high school teacher for no reason whatsoever, and may do so without affording him any prior hearing, it may not discharge a teacher merely because he has exercised his right to freedom of speech.).

87 Sniadach v. Family Fin. Corp., 395 U.S. 337, 342 (1965) (invalidating Wisconsin's pre-judgment wage garnishment procedures as violative of due process, in part because of the magnitude of the harm they inflicted upon the working poor).

88 See Goldberg v. Kelly, 397 U.S. 254, 263 (1970) (quoting Joint Anti-Fascist Refugee Comm. v. McGrath, 341 U.S. 123, 168 (1951) (Frankfurter, J., concurring)). See also Amett v. Kennedy, 416 U.S. 134, 211 (1974) (Marshall, J., dissenting).

80 It is apparent that this conclusion would not be accepted by at least three members of the Burger Court. In Flagg Bros., Inc. v. Brooks, 436 U.S. 149 (1978), the Court held that sale of goods entrusted to a warehouseman for storage, as permitted by New York law, was not "state action" for purposes of the fourteenth amendment. Justice Stevens, joined by Justices White and Marshall, wrote in dissent that a majority of the Court had never adopted the proposition that "since the State has the power to create property interests, it should also have the power to determine what procedures should attend the deprivation of those interests." Id. 169-70 n.3 (Stevens, J., dissenting).

This analysis of the Court's position is subject to question, however, given the 
proach of the plurality in Arnett, if adopted by the majority, would effectively overrule both the approach followed and the particular result reached in Goldberg $v$. Kelly. ${ }^{90}$

There are growing indications that the reasoning of the Arnett plurality is being extended to other areas. Although a majority of the Court failed to apply it to a case involving a due process claim to notice and hearing prior to suspension from public school, ${ }^{91}$

Court's statements on the matter in its most recent cases. In Flagg Bros. itself, the Court stated that a property interest

is not a monolithic, abstract concept hovering in the legal stratosphere. It is a bundle of rights in personalty, the metes and bounds of which are determined by the decisional and statutory law of the State of New York. The validity of the property interest ... . depends on New York law, and the manner in which that same property interest in these same possessions may be lost or transferred . . . likewise depends on New York law.

Id. 1735-36 n.10.

Moreover, in Memphis Light, Gas \& Water Div. v. Craft, 436 U.S. 1 (1978), the Court concluded that customers of a governmentally operated utility company had a property interest in continued service that was entitled to due process protection. In so holding, the Court relied upon Tennessee law, which was found not to permit a public utility to terminate service "at will" in the case of outstanding utility bills disputed by the customer. Id. 10-11. Importantly, however, the Court also noted that state law recognized an unqualified privilege to terminate service for non-payment of an undisputed charge. Id. $10 \mathrm{n} .9$. On the basis of this interpretation of Tennessee law, the Court strongly suggested that claims to continued service by customers who did not dispute an outstanding charge would not amount to property interests; as to these customers, the utility company indeed had "the power to determine what procedures should attend the deprivation," Flagg Bros., Inc. v. Brooks, 436 U.S. 149, 169-70 n.3 (1978) (Stevens, J., dissenting)-including no procedures at all. Presumably, if Tennessee law had qualified the utility's power to terminate service to customers whose bills were not disputed, they too would have been entitled to some constitutionally mandated procedural protection.

90397 U.S. 254 (1970).

91 Goss v. Lopez, 419 U.S. 565 (1975). In a 5-4 decision, the Court held that public school children have property and liberty interests in their education that qualify for due process protection, and that at least minimal procedural protections must be provided to students facing possible suspension.

Writing for the four dissenters, Mr. Justice Powell expressly endorsed the Arnett plurality's approach:

Thus the very legislation which "defines" the "dimension" of the student's entitlement, while providing a right to education generally, does not establish this right free of discipline imposed in accord with Ohio law. Rather, the right is encompassed in the entire package of statutory provisions governing education in Ohio- of which the power to suspend is one. 419 U.S. at 586-87 (emphasis added). For an in-depth discussion of Goss, see Wilkinson, Goss v. Lopez: The Supreme Court as School Superintendent, 1975 SUP. CT. REv. 25.

Justice Powell's endorsement of the "entire package" approach in Goss was somewhat enigmatic in view of his prior rejection of that view in his Arnett concurring opinion, see note 85 supra, and his opinion for the Court in Mathews v. Eldridge, 424 U.S. 319 (1976), in which he failed to adopt that approach. Since his Arnett concurrence was cited with approval in Mathews, 424 U.S. at 332, it is at least curious that the citation was not accompanied by an explanation or clarification, in light of his intervening Goss dissent. This apparent inconsistency is even more bewildering in light of the fact that Justice Powell was a member of the 
five Justices did adopt a strictly positivist approach in deciding whether constitutional protections apply to prohibit a state governmental entity from summarily dismissing its employee. In that case, Bishop $v$. Wood, ${ }^{92}$ Justice Stevens, writing for a bare majority, ${ }^{93}$ combined the Roth reasoning (due process clause property interests are created exclusively by reference to state law) with the Arnett plurality's "entire package" reasoning to hold that a non-probationary police officer from North Carolina was not entitled to any due process protection prior to employment termination. ${ }^{94}$

\section{The New Methodology and "Liberty" Interests}

In Roth, Arnett, and Bishop the Court dealt with claims that both property and liberty interests were being adversely affected by governmental action. These cases appeared more concerned with, and ultimately are more significant for, the appropriate analysis for identifying property interests protected by due process. ${ }^{95}$ Recent

5-4 majority in Bishop v. Wood, 426 U.S. 341 (1976), in which, notwithstanding its assertions to the contrary, id. 345 n.8, the Court adopted the Arnett plurality's "entire package" analysis.

92426 U.S. 341 (1976).

93 Justice Stevens wrote the opinion for the Court, joined by Chief Justice Burger and Justices Stewart, Powell and Rehnquist.

94 The Court in Bishop relied not upon express statutory procedures "qualifying" the employment interest, as in Arnett, but upon state court decisions holding that the relevant state statutes could "be construed as granting no right to continued employment but merely conditioning an employee's removal on compliance with certain specified procedures." 426 U.S. at 345. The Court attempted to distinguish the construction that six Justices had given the federal regulations involved in Arnett, 426 U.S. at 345 \& n.8, but the distinction is ambiguous at best. See Bishop v. Wood, 426 U.S. 341, 355-56 (1976) (White, J., dissenting). See generally AMERICAN CONSTITUTIONAI. LAw, supra note 54, at 432-35.

A majority of the Court has relied upon the Roth-Bishop analysis in concluding that some due process was operative in several cases decided after Bishop. See, e.g., Memphis Light, Gas \& Water Div. v. Craft, 436 U.S. 1 (1978) (termination of atility services); Dixon v. Love, 431 U.S. 105 (1977) (license revocation; however, no prior hearing required); Ingraham v. Wright, 430 U.S. 651 (1977) (corporal punishment of school children; no prior hearing required).

95 In Board of Regents v. Roth, 408 U.S. 564 (1972), the Court agreed with the plaintiff's argument that a person has a liberty interest in his "good name, reputation, honor, or integrity," but rather curtly concluded that that interest was not "at stake" in the case, due to the fact that no charges had been brought by the employer university. Id. 573. In Amett v. Kennedy, 416 U.S. 134 (1974), the plaintiff alleged that the charges on which his dismissal from federal employment was based effectively amounted to accusations of dishonesty, and that they infringed the liberty interest recognized in Roth. Id. 156. The plurality opinion, as well as the concurring opinion of Justice Powell, 416 U.S. 134, 164, 166, 170 (Powell, $\mathrm{J}_{\text {., }}$ concurring in part and concurring in the result in part), conceded the existence of a liberty interest, but concluded that statutorily prescribed procedures were adequate to protect that interest.

Similarly, in Bishop v. Wood, 426 U.S. 341 (1976), the plaintiff claimed that his employment termination infringed a reputation-based liberty interest. He also 
cases have indicated that a majority of the Court can be expected to approach the definition of protected liberty interests in the same way. If so, this trend would signal a significant departure from settled precedent.

In a variety of contexts, the Court has consistently defined liberty's contours in sweeping terms. In Meyer $v$. Nebraska, ${ }^{96}$ for example, the Court held that the liberty protected by the due process clause of the fourteenth amendment is broader than mere freedom from bodily restraint and that it includes:

the right of the individual to contract, to engage in any of the common occupations of life, to acquire useful knowledge, to marry, establish a home and bring up children, to worship God .... and generally to enjoy those privileges long recognized at common law as essential to the orderly pursuit of happiness by free men. ${ }^{97}$

Moreover, in reviewing state criminal convictions, the Court generally has taken an expansive view both of liberty and, more specifically, of the procedural protections that the fourteenth amendment implicitly guarantees to those, whose liberty the government contemplates infringing. This broad view has guided the Court's efforts to "incorporate" applicable provisions of the Bill of Rights into the due process clause and to make them enforceable in the state courts.98 In determining which specific provisions qualify for incorporation, the Court has used a variety of tests, each of which underscores the fundamental difficulty of reducing such concepts as liberty and due process to the static confines of language. For example, the Court has inquired whether the asserted guarantees

claimed that he had a liberty interest in not being discharged for reasons that were false. Id. 347. The Court disposed of the former claim by finding that the official communications advising him of his dismissal were not well publicized, id. 348-49; and it gave short shrift to the latter claim by finding that, for constitutional purposes, it was irrelevant whether the reasons precipitating his dismissal were based upon true or false information. Id. 349 \& n.I3. (1925).

96262 U.S. 390 (1923). See also Pierce v. Society of Sisters, 268 U.S. 510

97 262 U.S. at 399 . The vitality of this description was recently reasserted in Moore v. City of East Cleveland, 431 U.S. 494, 545 (1977) (White, J., dissenting):

The results reached in some of the cases cited by Meyer have been discarded or undermined by later cases, but those cases did not cut back the definition of liberty espoused by earlier decisions. They disagreed only, but sharply, as to the protection that was "due" the particular liberty interests involved.

98 See genetally G. Gunther, Cases and Materials on Constrtutional Law 506-47 (9th ed. 1975). 
are "implicit in the concept of ordered liberty," ${ }^{93}$ or are "basic to a free society." 100 On other occasions, attempts have been made to discern those rights included in "fundamental principles of liberty and justice that lie at the base of all our civil and political institutions" 101 and rights "basic in our system of jurisprudence" 102 or "fundamental to the American scheme of justice." 103

These tests and others, ${ }^{104}$ invariably defended by their proponents as principled in definition and application, ${ }^{105}$ reflect the Court's recognition of the dynamic nature of the values underlying due process. ${ }^{108}$ This awareness was perhaps most eloquently articulated by Mr. Justice Harlan, who wrote:

Due process has not been reduced to any formula; its content cannot be determined by reference to any code.

99 Palko v. Connecticut, 302 U.S. 319, 325 (1937).

100 Wolf v. Colorado, 338 U.S. 25, 27 (1949).

101 Powell v. Alabama, 287 U.S. 45, 67 (1932) (quoting Hebert v. Louisiana, 272 U.S. 312,316 (1926)).

102 In re Oliver, 333 U.S. 257, 273 (1948).

103 Duncan v. Louisiana, 391 U.S. 145, 149 \& n.11 (1968).

104 Although some Justices have viewed the fourteenth amendment's liberty as confined to some or all of the protections contained in the Bill of Rights, see, e.g., Adamson v. California, 332 U.S. 46, 71-72 (1947) (Black, J., dissenting), others have felt less restricted, see, e.g., Duncan v. Lousiana, 391 U.S. 145, 174 (1968) (Harlan, J., dissenting) ("In my view, ... the first section of the Fourteenth Amendment was meant neither to incorporate, nor to be limited to, the specific guarantees of the first eight amendments."); cf. Adamson v. California, 332 U.S. 46, 124 (1947) (Murphy, J., dissenting) ("But I am not prepared to say that the [first section of the fourteenth amendment] is entirely and necessarily limited by the Bill of Rights.").

105 See, e.g., Moore v. City of East Cleveland, 431 U.S. 494, 503 \& n.12 (1977) (plurality opinion), and the dissenting opinion of Justice White. Id. 541 (White, J., dissenting). See generally Kadish, supra note 1, at 319.

100 In other contexts as well, the Court has shown substantial flexibility in defining the liberty protected by due process. In a recent revival of the substantive due process doctrine, the Court has found a constitutional right to privacy whose "core" consists of a freedom to control decisions pertaining to private family life without undue government interference. See, e.g., Smith v. Organization of Foster Families for Equality \& Reform, 431 U.S. 816 (1977); Whalen v. Roe, 429 U.S. 589 ( 1977 ); Roe v. Wade, 410 U.S. 113 (1973); Griswold v. Connecticut, 381 U.S. 479 (1965). The ultimate scope of this privacy right remains undefined. Whalen v. Roe, 429 U.S. at 599 n.24.

Several distinct approaches have been used in an effort to identify the source of this right. They have included analyses of express notions of personal liberty protected by the fourteenth amendment, see, e.g., Roe v. Wade, 410 U.S. at 153; inquiries concerning the "penumbras" and "emanations" of the Bill of Rights, see, e.g., Griswold v. Connecticut, 381 U.S. at 484 (plurality opinion of Douglas, J.); and an explication of "the language and history of the Ninth Amendment," id. 487 (Goldberg, J., concurring).

For a further discussion of the Court's treatment of the right to privacy, see Ely, supra note 6 . 
The best that can be said is that through the course of this Court's decisions it has represented the balance which our Nation, built upon postulates of respect for the liberty of the individual, has struck between that liberty and the demands of organized society. . . .

... This "liberty" is not a series of isolated points pricked out in terms of the taking of property; the freedom of speech, press, and religion ... and so on. It is a rational continuum which, broadly speaking, includes a freedom from all substantial arbitrary impositions and purposeless restraints. ...107

Recently, however, in its noncriminal procedural due process cases, the Court has adopted still another approach to defining the scope of liberty protected by the fifth and fourteenth amendments. This approach, which is much more restrictive than its predecessors, appears to parallel closely or overlap the Roth-Arnett (plurality)Bishop property analysis. The first evidence of this shift in methodology appeared in Wolff $v$. McDonnell, ${ }^{108}$ which concerned due process in prison disciplinary proceedings. The issue before the Court was whether prison officials could summarily revoke "goodtime" credits previously earned by prisoners. The state argued that because "good-time" credits were a creation of state law, they were not protected by the Constitution even from arbitrary infringement. In response, the Court noted that while the "Constitution itself does not guarantee good-time credit for satisfactory behavior while in prison," the state had "provided a statutory right to good time," and that the prisoners' interest "has real substance and is sufficiently embraced within Fourteenth Amendment 'liberty" to entitle it to due process protection. ${ }^{109}$ In so reasoning, the Court concluded that "a person's liberty interest is ... protected, even when the liberty itself is a statutory creation of the State." 110 Thus, a new source of liberty was recognized-a source originating not in the Constitution itself or in natural law, but in state-created positive law.

Although Wolff ultimately held that even state-created liberties are subject to the mandates of due process, Justice White's majority opinion left open the possibility that a state, if it so desired, could condition the creation of a liberty interest (as Nebraska

107 Poe v. Ullman, 367 U.S. 497, 542-43 (1961) (Harlan, J., dissenting). 108418 U.S. 539 (1974).

109 Id. 557.

110 Id. 558 (emphasis added). 
had not done) upon prescribed and limited procedural protections, and thereby circumvent the more exacting requirements of due process; or, more drastically, that a state could even extinguish a liberty interest entirely, simply by voting it out of existence. This analysis, based upon the concept of state-created liberties, reached its logical culmination in Meachum v. Fano, ${ }^{111}$ in which the Court held that state prisoners have no due process rights to notice or hearing prior to being transferred from one state prison to another, even though the transfers are avowedly punitive, and even when the conditions in the receiving facility are substantially more restrictive than those in the transferring facility.

The Court reasoned that, just as the Constitution includes no right to "good-time" credits, it also fails to provide a right of prisoners to remain in a particular penal facility during good behavior. If such a right were to exist at all, it would have to be a creation of state law. In the absence of state laws, rules, or practices conditioning punitive transfers on proof of serious misconduct, or on other specified factors, ${ }^{112}$ the Court concluded that even arbitrary transfers, based upon erroneous factual conclusions, did not implicate inmates' liberty interests.

As with the property clause cases, the Court's approach to liberty has been ambivalent and in flux. No clear majority view has been consistently voiced. For example, in Smith v. Organization of Foster Families for Equality \& Reform, ${ }^{113}$ the Court relied upon positive law in determining whether a liberty interest was at stake, but did so in a way which indicated that state law may not necessarily be the exclusive source of inquiry. In Smith, the Court was asked to find a constitutionally protected privacy interest in the relationship between foster parents and their foster children. Although ultimately assuming that such an interest was embraced within due process clause liberty, Justice Brennan, writing for himself and five other Justices (White, Marshall, Blackmun, Powell and Stevens), noted that its source and contours were to be found "not in state law, but in intrinsic human rights, as they have been understood in 'this Nation's history and tradition." "114 Continuing, he wrote:

While the Court has recognized that liberty interests may in some cases arise from positive law sources, see, e.g., Wolff

111427 U.S. 215 (1976).

112 Accord, Montanye v. Haymes, 427 U.S. 236 (1976).

113431 U.S. 816 ( 1977 ).

114 Id. 845 (footnote omitted). 
v. McDonnell, 418 U.S. 539, 557 (1974), in such a case, and particularly where, as here, the claimed interest derives from a knowingly assumed contractual relation with the State, it is appropriate to ascertain from state law the expectations and entitlements of the parties. ${ }^{115}$

As this language suggests, the Court's opinion is fraught with ambivalence, ${ }^{116}$ which seems to indicate disagreement within the majority as to the situations in which state law should define liberty and the degree to which state law should control that definition. Because the Court in recent cases had found the constitutional privacy right to be implicit in liberty itself, there was no apparent need to rely upon extra-constitutional sources to define the foster family relationship. ${ }^{117}$ Instead, the Court was apparently prompted by a desire to avoid the thorny problem that would have been presented if both the foster and natural family relationships were found to have been protected by a right to privacy defined exclusively by a constitutional source; in that case, the Court would have been forced to balance two constitutionally protected liberties. In this regard, the concurrence of Justices White, Blackmun and Powell in the Smith majority opinion, viewed in the context of their votes in the majority in Meachum $v$. Fano, ${ }^{118}$ indicates that they would regard state law as the exclusive source of protected liberty interests in at least some (though perhaps not all) classes of cases, including those involving the claims of state prisoners. ${ }^{119}$ Moreover, Justice Stewart, joined by Chief Justice Burger and Justice Rehnquist, concurring in the judgment in Smith, refused to recognize the constitutional source of liberty; instead, he viewed the Roth property analysis as controlling. ${ }^{120}$ In short, a majority of the Justices have concluded that in certain situations,

115 Id. 845-46 (emphasis added).

$116 \mathrm{Mr}$. Justice Stewart characterized the Court's approach as "tiptoeing around [the] central issue." Id. 857-58 (Stewart, J., concurring in the judgment).

117 See note 106 supra.

118427 U.S. 215 (1976). Justice White wrote the opinion for the Court; he was joined by Chief Justice Burger and Justices Stewart, Blackmun, Powell and Rehnquist.

119 It is difficult to forecast whether Justices White, Blackmun and Powell will expand this exclusive reliance upon state law into other areas. Although Professor Tribe has offered the view that the Meachum Court "may have intended to confine its newly limited application of the entitlement concept" to cases involving state prisoners, AMERTCAN CONSTiTUTional LAw, supra note 54, at 526, it is noteworthy that the Chief Justice and Justices Stewart and Blackmun viewed state law as dispositive of the "liberty" claim in Smith. 431 U.S. 816, 859 (1977) (Stewart, J., joined by Burger, C.J., and Rehnquist, J., concurring in the judgment).

120 Id. 858 (Stewart, J., concurring in the judgment). 
whose parameters are as yet undefined, the state has exclusive authority to create, control, and restrict liberty, just as it has with property interests. The implications of this conclusion will next be examined.

\section{The Greation of a Constitutional Vacuum: Methodology Unresponsive to Due Process Values}

As the above discussion indicates, the Court's evolving methodology in procedural due process cases clearly threatens to create a constitutional vacuum of even greater dimensions than that which existed prior to the Goldberg $v$. Kelly decision. ${ }^{121}$ Even in the preGoldberg era, under the regime of a methodology that recognized fundamental distinctions between rights and privileges, ${ }^{122}$ a court was at least theoretically free to conclude that the effect of governmental conduct upon even "gratuitous benefits" was so arbitrary that some procedural protection was constitutionally mandated. ${ }^{123}$ But the Court's current approach, which premises the recognition of liberty or property interests in governmental largess upon the express statutory, common law, or other positivist guarantee of such interests, effectively drains due process of most, if not all, of its substance as an independent constitutional restraint on even the most arbitrary and severe forms of governmental conduct.

These recent developments have seriously impaired, if not crippled, the ability of the due process clause to respond to the underlying values articulated in this Article. ${ }^{124}$ With regard to property interests, Roth, Bishop, and the Arnett plurality point to positive law, in the form of legislative and administrative policies and regulations and decisional law, as the exclusive source for substantive interests qualifying for any procedural protections. ${ }^{125}$ In contrast to that period immediately following the demise of the right-privilege dichotomy, when entitlements created by statute were accorded the full constitutional honors extended to the more tradi-

121 Goldberg v. Kelly, 397 U.S. 254 (1970); see text accompanying notes 67-72 supra.

122 See Demise of Right-Privilege Distinction, supra note 68.

123 See, e.g., Flemming v. Nestor, 363 U.S. 603 (1960) (federal Social Security beneficiaries entitled to due process protection); cf. Sherbert v. Verner, 374 U.S. 398 (1963) (invalidating, as an unconstitutional restriction upon freedom of religion, a state law that denied unemployment compensation benefits to those unavailable for Saturday work). See generally Brudno, Fairness and Bureaucracy: The Demise of Procedural Due Process for Welfare Claimants, 25 Hastings L.J. 813 (1974).

124 See text accompanying notes 12-60 supra.

125 See generally Shapiro, Mr. Justice Rehnquist: A Preliminary View, 90 HARv. L. REv. 293, 322-26 (1977). 
tional common law forms of property, ${ }^{126}$ the strict or narrow entitlement theory now applied by the Court creates what has been described as a "Kafkaesque absurdity," ${ }^{127}$ leaving little or no room for the recognition of a zone of constitutional protection that would immunize governmentally-created property or liberty interests against arbitrary infringement. Thus, the legislature is left free to dispense, modify, or revoke society's bounty upon any condition it chooses or, indeed, upon no condition at all. Although substantive constitutional restrictions would still prevail, ${ }^{128}$ no procedural safeguards would obtain unless the legislature gratuitously included them in the statutory scheme. ${ }^{129}$ As applied to liberty interests, governmental action left so unrestrained could threaten very real and substantial physical and emotional deprivation. ${ }^{130}$ In essence, this methodological shift represents a full-circle return to the interpretation given by the medieval English courts to the "law of the land" clause of the Magna Carta-thus reducing due process to a bare assurance of legal process. Such an approach was expressly rejected by the Court 120 years ago. ${ }^{131}$

These developments clearly threaten to subvert both the substantive and inherent dignitary values previously described as cen-

126 See, e.g., Bell v. Burson, 402 U.S. 535 (1971) (driver's licensees entitled to due process protection, including hearing prior to license revocation). Cf. Dixon v. Love, 431 U.S. 105 (1977) (upholding statutory procedures for license revocation). See generally Cracks in "The New Property," supra note 69, at 455-57.

127 Tribe, Structural Due Process, 10 HARv. C.R.-C.L. L. REv. 269, 277 (1975).

128 For example, the state would presumably be unable to retract its largess under conditions which abridged an undividual's first amendment rights. See, e.g., Mit. Healthy City School Dist. v. Doyle, 429 U.S. 274 (1977), described in note 86 supra.

129 See, e.g., Grace Towers Tenants Ass'n v. Grace Hous. Dev. Fund Co., 538 F.2d 491 (2d Cir. 1976), holding that tenants of federally subsidized housing project were not constitutionally entitled to notice and hearing prior to a $23 \%$ rent increase. Citing Roth, the court said: "Without at least some Congressionally prescribed restrictions on the agency's [U.S. Department of Housing and Urban Development] action or a practice giving rise to a legitimate expectation, we are constrained to find that plaintiffs' interest in the benefit of low-cost housing does not rise above 'an abstract need or desire for it . . . " Id. 494. Contra, Geneva Towers Tenants Organization v. Federated Mortgage Investors, 504 F.2d 483 (9th Cir. 1974) (finding a property interest premised on tenants' statutorily created expectation of continued receipt of low cost housing).

130 In Meachum v. Fano, 427 U.S. 215, 224 (1976), even while finding that prisoners were not protected by due process from arbitrary transfers, the Court conceded that changes in conditions of confinement might have substantial physical adverse impact on prison inmates. It is quite apparent that the termination of unprotected benefits such as public employment could easily lead to financial disaster and thus also entail real physical hardships. See, e.g., Mathews v. Eldridge, 424 U.S. 319, 349-50 (1976) (Brennan, J., dissenting).

131 Murray's Lessee v. Hoboken Land \& Improvement Co., 59 U.S. (18 How.) $272(1856)$. 
tral to due process fairness. ${ }^{132}$ With regard to substantive values, the individual is now left at the mercy of government's "procedural grossness." ${ }^{133}$ She is precluded from obtaining an impartial determination of the legal justification for the governmental action. Moreover, under these conditions, she can no longer even expect that deprivatory official conduct will be premised upon an accurate determination of facts; the outcomes of such conduct are not likely to be compatible even with substantive criteria of fairness. ${ }^{134}$ There seems little reason for confidence that government officials responsible for decisions pertaining to access to or retention of entitlements will consistently apply relevant standards in a neutral and accurate manner. ${ }^{135}$ Moreover, states will probably be tempted to dilute or to eliminate existing statutory or regulatory standards now limiting official discretion in denying, modifying, or revoking entitlements. The Roth-Bishop-Meachum definition of protected interests, wholly dependent upon reference to positive law, clearly countenances such a prospect; inducements to curtail due process, such as administrative flexibility and efficiency, may prove irresistible to legislators increasingly concerned about efficient allocation of scarce resources.

The impact of the Roth-Bishop-Meachum approach upon inherent due process values-previously defined in terms of individual autonomy, integrity and self-respect ${ }^{136}$-suggests even bleaker consequences. The Gourt's decisions have relieved government officials of the constitutional obligation to provide an opportunity for

132 See text accompanying notes $34-60$ supra.

133 Cracks in "The New Property," supra note 69, at 450 . Although appropriate in a descriptive sense, I use the term "procedural grossness" in a somewhat broader sense than does Professor Van Alstyne, who applies it to characterize a method of interaction between the government and individuals that "builds in such a large margin of probable mistake as itself to be intolerable in a humane society." Id. In my view, the actual or potential grossness associated with the absence of protective procedures-or with the "voluntary" provision of the pro-forma procedures provided in cases like Bishop v. Wood, 426 U.S. 341 (1976)-relates as much to its failure to protect what $I$ have defined as inherent dignitary values.

For a discussion of the connection between due process and substantive, or outcome-related, values, see notes $35 \& 39$ supra and text accompanying notes $34-40$ supra.

134 It has been contended that the basic aim of procedural due process is accuracy in the determination of claims. Management Side of Due Process, supra note 35. To the extent that accuracy depends upon a reliable determination that acknowledged and legitimate reasons exist for deprivatory official action, it is difficult to see how such conditions can be satisfied in a nondiscriminatory fashion when the agent initiating the deprivation is either not bound by substantive limitations or applies applicable limitations free from independent evaluation. See Bishop v. Wood, 426 U.S. 341, 355 (White, J., dissenting).

135 See, e.g., Arnett v. Kennedy, 416 U.S. 134, 216 (Marshall, J., dissenting). 136 See text accompanying notes 50-56 supra. 
confrontation, and left them free to deny entitlement holders any participation in the decisionmaking and implementation processes; thus, their responsiveness to these dignitary values will depend upon voluntarily adopted policies or the individual discretion of administrative agencies or personnel. Under such a regime, it might be possible to expect that substantive dignitary values will sometimes be served, ${ }^{137}$ assuming that internal and external political pressures operate upon decisionmakers to establish formal or informal guidelines delineating the boundaries of official discretion. ${ }^{138}$ It might even be assumed that bureaucrats will not intentionally ignore their own rules, and that they will apply existing eligibility criteria in good faith. However, to the extent that inherent dignity exists as a concept independent of substantive outcomes-as I have contended above ${ }^{139}$-there is no similar reason to believe that political pressure will enforce official observance of inherent dignitary values.

The proposition thus far advanced-that an entitlement program left unrestrained by constitutionally-mandated procedural safeguards will be predictably less responsive to inherent dignitary values, and possibly to substantive ones as well-is premised upon a particular conception of prevalent social philosophy in the welfare state. For example, it has been demonstrated in the context of existing schemes for income redistribution ${ }^{140}$ that society's support for entitlement programs tends to be mixed. ${ }^{141}$ Popular ambivalence-or even hostility-toward the poor as individuals is often combined with a more generalized and benign desire to prevent

137 This assumption may ultimately be fallacious. See, e.g., Management Side of Due Process, supra note 35 (concluding, inter alia, that even when procedural safeguards or opportunities for appeal are imposed upon administrative processes, the procedures may nevertheless be incapable of protecting substantive values).

138 For an interesting discussion, drawn from a slightly different context, of the extent to which administrative agencies, which frequently constitute the vehicle through which deprivatory, non-criminal government action is effected, are insulated from general public pressures, see Johnson, A New Fidelity to the Regulatory Ideal, 59 GEO. L.J. 869, 873-74 (1971).

139 See notes 39-60 supra \& accompanying text.

140 Although public welfare programs may not provide a paradigm of an entitlement program's inherent responsiveness to the values in question, the analogy seems particularly appropriate in view of the comparatively low senses of selfesteem, integrity, and autonomy that welfare recipients often carry into their interactions with administrative agencies. See, e.g., Briar, Welfare From Below: Recipients' Views of the Public Welfare System, 54 CaLrF. L. Rev. 370 (1966). To the extent that such persons in fact have much lower senses of self-esteem than do others, they have greater need of procedures designed to safeguard inherent dignitary values.

141 See genetally J. Feagin, Subordinativg the Poor: Welfare and AmERtcan Beliefs (1975). 
at least absolute suffering and deprivation; ${ }^{142}$ these are joined with a further desire to preserve the status quo. ${ }^{143}$ Against this background, it is quite likely that entitlement systems, especially those involving the poor, may be subjected to political restraints designed to assure accuracy in terms of substantive outcomes, without being subjected to concomitant pressures militating toward responsiveness to inherent dignitary values. In other words, if agencies or officials administering entitlement programs fail to devise, adopt, or implement processes for deprivatory action that respond to inherent dignitary values, it seems highly unlikely that such processes will be imposed upon them through non-judicial means. ${ }^{144}$

Because the unchecked political processes cannot be expected voluntarily to integrate procedural protections designed to protect inherent dignitary values into statutory entitlement schemes, full implementation of due process values cannot be achieved without judicial intervention. But Roth and its progeny preclude the courts from designing more appropriate protections. Accordingly, this Article will explore alternatives to the Roth-Bishop-Meachum methodology which might offer greater promise for vindication of due process values.

\section{Structuring Responsive Methodology: Alternatives TO THE Roth-Bishop-Meachum ANALYSIS}

As the previous discussion has demonstrated, the Roth-BishopMeachum methodology is incapable of safeguarding the dual nature of due process values. It is therefore necessary to explore and discover alternative modes of analysis that would be more responsive to due process values, yet defensible under the traditional criteria of legitimacy used in constitutional interpretation. I will next

142 For a general discussion of this proposition, see Jacobs, America's Schizophrenic View of the Poor, in Poverty: VIEwS FROM THE LEFT 39-57 (J. Larner \& I. Howe eds. 1968).

143 See, e.g., J. FEAGIN, supra note 141, at 52-53 (1975) ("The goals of the welfare system constitute a paradoxical mixture of charitable impulses and concern for the maintenance of social order.").

144 In several relevant respects, the actions of administrative agencies have been viewed as generally not subject to public scrutiny. See generally Cramton, The Why, Where and How of Broadened Public Participation in the Administrative Process, 60 GEO. L.J. 525 (1972). Moreover, the regulated have very little control over the regulators; this is even more true with respect to the poor, upon whom administrative action has a particularly heavy impact. Cf. Bonfield, Representation for the Poor in Federal Rulemaking, 67 Mrch. L. Rev. 511 (1969). This general lack of public participation in administrative processes was viewed as a very serious problem by then Circuit Judge Warren Burger, writing for the court in Office of Communication of the United Christ Church v. FCC, 359 F.2d 994, 1004-06 (D.C. Cir. 1966). 
sketch two such alternatives; will illustrate their application with a concrete, workable model; and finally, will suggest reasons for concluding that these alternatives are doctrinally viable.

\section{A. Broadening the Definition of "Liberty"}

The first alternative, which might appropriately be described as an extension of the Roth-Bishop-Meachum analysis, focuses upon the "liberty" that the due process clause serves to protect. As has already been noted, ${ }^{145}$ at least until the Roth decision, the scope of constitutionally protected liberty had been considered to be quite expansive. Under the suggested approach, the Court would expand the existing definition of liberty and recognize as coming within its scope the individual's right to be free from arbitrary governmental actions that threaten inherent dignitary values. Under this approach, the Court could still begin its inquiry by searching through specific positive law grants of substantive and procedural entitlements to determine whether there existed a liberty interest sufficient to trigger due process protections. The difference would be, however, that this inquiry would be only the first step in the analysis. After examining the terms or conditions, if any, upon which a statutory scheme makes the continued enjoyment of substantive entitlements depend, the Court might well find that these are sufficiently protective of substantive and inherent dignitary values, and thus declare that no additional safeguards would be required. ${ }^{140}$ But if it found, instead, that the statutes included no provisions governing the conditions upon which the substantive entitlements could be terminated or diminished, the Court would order new or additional safeguards. ${ }^{147}$ By thus expanding the ambit of liberty to

145 See note 106 supra and text accompanying notes 95-107 supra.

146 For a discussion of specific procedures at least minimally sufficient to safeguard inherent dignitary values, see text accompanying notes 178-295 infra.

$147 \mathrm{In}$ applying this analysis, the Court would also need to identify the extent to which procedural safeguards incorporated within the entitlement scheme differ in their adequacy for protecting substantive, as opposed to inherent, values. See generally text accompanying notes 178-295 infra. Thus, even though the statutes provide for an opportunity to submit written statements, documents, or other evidence prior to termination or modification of benefits-and this is deemed sufficient to guarantee at least minimal protection for the substantive values of accuracy and reliability, see, e.g., Mathews v. Eldridge, 424 U.S. 319 (1976)-these safeguards may be inadequate to assure the sort of personal participation that might be viewed as essential for the protection of inherent values, in which case additional safeguards should be required. In this regard, an approach that deemphasizes the importance of the values of personal participation and explanation must be cautiously assessed. This point has not been fully appreciated in some recent scholarly commentary. See, e.g., Rabin, supra note 81; Rubenstein, supra note 36.

This distinction is critical. Professor Michelman has noted that, under a Roth-type analysis, the identification of an entitlement sufficient to trigger due 
include inherent dignitary values, colorable due process claims would be triggered whenever deprivatory action is threatened, regardless of whether the target of such action is the individual herself ${ }^{148}$ or some material object to which claims of entitlement have attached. ${ }^{149}$

Of course, many procedural due process cases raise claims of infringement of both (intangible) liberty interests and (tangible) property interests. ${ }^{150}$ It is important to recognize, however, that the liberty interest advocated here is quite different from the one typically asserted in those due process cases. The latter is a reputational right, and is usually defined in terms of personal honor ${ }^{151}$ or of stigmatization that tends to restrict social and economic opportunities. ${ }^{152}$ Recently, in Paul $v$. Davis, ${ }^{153}$ the Court rejected the view that at least the abstract form of reputational liberty is entitled to due process protection in its own right. ${ }^{154}$ But this conclusion in no way forecloses the Court from recognizing that inherent dignitary values are embraced within due process liberty. These

process protection will require an application of explanatory procedures, and that "nonformal as well as formal aims may be incidentally served." Formal and Associational Aims, supra note 35 , at 132 . It is my view that the due process protections currently viewed as acceptable to the Court are adequate to protect both substantive and inherent values, if at all, only in ways that are so "incidental" as to be fortuitous. See, e.g., Ingraham v. Wright, 430 U.S. 651 (1977).

148 See, e.g., Wolff v. McDonnell, 418 U.S. 539 (1974) (deprivation of goodtime credits, which constituted a liberty interest).

149 See, e.g., Mathews v. Eldridge, 424 U.S. 319 (1976) (termination of disability benefits); Goldberg v. Kelly, 397 U.S. 254 (1970) (termination of welfare benefits).

150 See, e.g., Bishop v. Wood, 426 U.S. 341 (1976); Paul v. Davis, 424 U.S. 693 (1976); Wisconsin v. Constantineau, 400 U.S. 433 (1971). \& n.50.

151 See generally, The Supreme Court, 1975 Term, 90 HaRv. L. REv. 55, 93-94

152 See, e.g., Bishop v. Wood, 426 U.S. $341,347-49$ (1976); Board of Regents v. Roth, 408 U.S. 564, 572-75 (1972).

153424 U.S. 693 (1976).

154 Paul held that one must allege more than a bare abstract injury to reputation to state an actionable due process claim; for example, an allegation that an accompanying liberty or property interest recognized and protected by state law had been infringed would probably be sufficient. Thus, the Court did not preclude the possibility that reputational injuries that had the effect of jeopardizing the exercise of constitutionally cognizable liberty interests, such as a right to contract or make a living, cf. Meyer v. Nebraska, 262 U.S. 390, 399 (1923) (listing rights included within protected liberty), might be so actionable. Although Davis had alleged that, by designating him a shoplifter, the police "seriously impair[ed] his future employment opportunities," 424 U.S. at 697, the Court apparently chose to emphasize the fact that Davis had not in fact been fired from his employment as a result of the police conduct. Id. 696, 710 .

Moreover, in Bishop v. Wood, 426 U.S. 341, 348-49 (1976), the Court took pains to point out that there had been no publication of any allegations that might have jeopardized Mr. Bishop's employability. For a more extensive analysis of this issue, see Cracks In "The New Property," supra note 69, at 478-80. 
values can be distinguished in several respects from the reputational interest that the Court refused to recognize in Paul. First, as the Court clearly noted in that case, an alleged intrusion into purely reputational interests is typically actionable in virtually every state through a tort claim in defamation. But because a claim for violation of inherent dignitary values-embodying concepts of self-respect, autonomy, and individual integrity ${ }^{155}$-would generally not be actionable under state tort law, ${ }^{150}$ there is no risk that extending due process protections to such values would threaten the "constitutionalization of tort law" that the Court saw as anathema. ${ }^{157}$ More important, however, is the fact that inherent dignitary values exist independently of substantive values (measured in monetary terms or otherwise ${ }^{158}$ ), and that due process has traditionally been regarded as primarily a preventive principle rather than a compensa-

155 See text accompanying note 56 supra.

156 Although injury to reputation is generally cognizable under the common law of defamation, most recognized categories of defamation are directed toward compensating a victim for pecuniary loss suffered as a result of the defamatory act. Consequently, in most cases, an individual would have to plead special damages in order to recover. W. Prosser, LAw of Torxs 760-62 (4th ed. 1971). Moreover, in those cases in which it is not necessary to allege special damages, the defamatory act is presumed by law to occasion pecuniary loss. Id. 754-60. Furthermore, the Court's recent attempts to articulate the nature of first amendment immunity from liability for defamation, when read in light of Paul v. Davis, have raised considerable doubt concerning the extent to which injury to reputational interests inflicted by public officials may constitutionally be made actionable. See generally Christie, Injury to Reputation and the Constitution: Confusion Amid Conflicting Approaches, 75 Micr. L. Rev. 43 (1976).

In this regard, although some jurisdictions now recognize the tort of intentional or negligent infliction of mental distress, W. Prosser, supra, at 49-62, 327-35, concepts of official and sovereign immunity often immunize officials from personal liability. Cf. Paul v. Davis, 424 U.S. 693, 715 (1976) (Brennan, J., dissenting) (Court should inquire whether an adequate state remedy actually exists, or whether officials "would be immunized by state doctrines of official or sovereign immunity."). Moreover, these tort actions are generally unavailable in most states.

It is important to note that even if state tort law generally recognized liability of public officials for infliction of mental distress, the remedy, defined in monetary awards, would be inadequate. The inherent dignitary values at issue are derived from a core concept of individuality and autonomy. Although empirical evidence may be unavailable, it seems to me that a diminution of self-respect or self-esteem associated with being treated as a mere object-as a means in the Kantian sense, see note 32 supra-cannot be fully redressed through a subsequent dollar judgment against the official actor. This view has been reflected in traditional analysis of the purpose of the law of torts, see, e.g., F. PoLcock, Torrs 181 (15th ed. 195I), and has been advanced by other commentators. See, e.g., Monaghan, supra note 71, at 433 .

157 Paul v. Davis, 424 U.S. 693, 698-99 (1976). It is also noteworthy that under the general law of defamation, truth of the alleged defamatory statement constitutes a defense to liability. But the truth or accuracy of the data upon which intrusive official conduct is premised, while central to notions of substantive dignity, is less crucial to inherent values. See generally text accompanying notes 34-60 supra.

${ }^{158}$ See note 39 supra and text accompanying notes 34-39 supra. 
tory one. ${ }^{159}$ Consequently, deference to the potential availability of damages in a common law tort action simply ignores the fundamental role of due process in preventing arbitrary governmental conduct.

There is at least one other respect in which Paul need not preclude the Court from broadening its definition of liberty to include inherent dignitary values. The reputational interest denied constitutional protection in Paul is significantly less important than the liberty interest discussed here in defining the relationship between the government and individuals in the constitutional scheme. Although all governmental action that negatively affects individuals implicates dignitary values, ${ }^{160}$ it need not adversely affect the sort of reputational interests that were denied constitutional protection in Paul $v$. Davis. Thus, while the summary termination of employment involved in Bishop would inevitably be perceived by Mr. Bishop as arbitrary, demeaning, and dehumanizing, it would not necessarily have the effect of damaging his reputation or the esteem in which he was held in his community; ${ }^{161}$ nor would it necessarily diminish the range of social and economic opportunities otherwise available to him. Although his reputation in the community might survive the discharge, his selfesteem would clearly be injured by the summary character of his dismissal. In at least this sense, governmental deprivations, carried out summarily and inexplicably, threaten more pervasive, destructive injury to inherent diginitary values than to reputational interests. ${ }^{162}$

Although I will postpone, for the moment, an attempt to suggest ways in which the expanded definition of liberty suggested here can be supported as a legitimate exercise of the Court's power,

159 See, e.g., Ingraham v. Wright, 430 U.S. 651, 695-97 (1977) (White, J., dissenting).

100 See text accompanying notes 34-60 supra.

181 The extent to which adverse governmental acts, such as summary termination of employment or of social security benefits, would effect such a reputational interest might depend upon such factors as the nature and extent of publication of the grounds for termination and the affected individual's opportunity for subsequent explanation of those grounds.

162 When the governmental act in question does result in the sort of stigmatization that not only detracts from the affected person's reputation but also restricts her economic opportunities, Paul and Bishop arguably leave room for the application of due process protection. But even if this proves not to be the case, there seems to be a deeper dimension to the very personalized damage caused by governmental conduct which totally disregards the intrinsic sense of self-worth and individuality we all possess and strive to preserve. It is this subjective sense of self that exists apart from-and indeed transcends-both the way in which we are perceived by others and the material gains we are able to achieve. 
at least one such observation seems appropriate at this point. As recently noted by Professor Van Alstyne, the inclusion within due process liberty of inherent interests not traceable to legislatively created substantive entitlements "does not lack text, logic, flexibility, or precedent." ${ }^{163}$ The restrictive methodology of Roth, Bishop, and Meachum is no more compelled by a clear reading of the constitutional text than was the more open-ended approach taken by the Warren Court in the Goldberg era. Moreover, the approach suggested here provides some protection against the spectre of total subservience of the individual to government and the bureaucracy that it spawns. ${ }^{164}$

\section{B. Granting Independent Significance to the Due Process Clauses: The Interface of Substance and Procedure}

A second methodological alternative to the Roth-BishopMeachum analysis, capable of at least minimally responding to substantive and inherent values, would acknowledge an independent, substantive content of due process itself. According to this ap. proach, the due process clauses would be recognized as having their own bottom; they woud manifest the general proposition that government is precluded from interacting with individuals in ways that have the effect of ignoring or infringing basic individual dignity. The proffered methodology would be free of the mechanical probing that has characterized the Court's quixotic search for selflimiting standards defining the boundaries of "life", "liberty," and "property." ${ }^{165}$ Instead, by viewing the due process guarantee per se stans as symbolizing an ideal of fairness applicable to deprivatory

163 Cracks In "The New Property," supra note 69, at 488.

164 Professor Van Alstyne posits that the due process clauses were designed to provide "the more general protection of the old liberty, i.e., those personal freedoms sheltered from government in all its protean exercises of power." Id. 487 (emphasis in original). He further states that it is "plausible to treat freedom from arbitrary adjudicative procedures as a substantive element of one's liberty as well . . . ." Id. (emphasis in original). Although I concur in this analysis, my reasons for doing so pertain as much to the fact that arbitrary adjudicative procedures subvert the more abstract values of personality as to the risks of unreliability that they create. In this respect, my concerns for the dangers of governmental arbitrariness are more akin to those expressed by Professor Monaghan. See generally Monaghan, supra note 71, at 432-33. See also American Constitutional Law, supra note 54, at 560.

165 The extreme confusion and ambiguity associated with the attempt satisfactorily to define protected liberty and property interests was most recently acknowledged by Justice Rehnquist, one of the staunchest supporters of the new definition. Writing as Circuit Justice in New Motor Vehicle Bd. v. Fox Co., 434 U.S. 1345 (1977), he noted: "Our cases in this difficult area do not offer crystal clear guidance, and I venture my own analysis of the problem fully realizing that it is not apt to be the last word authoritatively spoken on the subject." Id. 1348. 
governmental action, the Court would be able to ensure that both the substantive and inherent faces of that ideal were respected. ${ }^{166}$ In applying this analysis, the Court would assess the extent to which specific deprivations were accomplished with at least minimal assurances of accuracy and reliability, while concomitantly determining whether the processes through which those deprivations were effected provided at least minimal opportunity for the sort of personal participation, revelation, and explanation necessary to protect individual dignity. ${ }^{167}$

The suggested approach, which treats the due process clause as an independent standard of fairness, is premised upon the dual propositions that people have a protected entitlement to due process, and that their entitlement is not inherently and inexorably connected to the quality or quantity of the object or interest against which governmental conduct is directed. Inevitably, this approach will draw criticism. It might be suggested that the proffered analysis represents a revision, if not a perversion, of the constitu-

166 As previously noted, many forms of procedural protection might adequately serve interests in accuracy and reliability without serving inherent values. See note 147 supra.

${ }^{167}$ Although the Court's recent decision in Carey v. Piphus, 435 U.S. 247 (1978) may, on its surface, indicate at least an implicit concern for these inherent values in its procedural due process methodology, fuxther reflection upon that case leads to a contrary conclusion. In Carey, the Court held that a violation of procedural due process rights gives rise to an action for compensatory damages under 42 U.S.C. $\$ 1983$ (1976). The Court concluded that, aside from recovery for damages attributable to more substantive injuries sustained, an individual could recover for objectively provable mental and emotional distress which, the Court seems to have conceded, might stem from the denial of a "feeling of just treatment." Id. 261 (quoting Joint Anti-Fascist Refugee Comm. v. McGrath, 341 U.S. 123, 162 (1951) (Frankfurter, J., concurring)). Even assuming arguendo that the "distress" described in the Court's opinion, id. 264 n.20, is closely related to the concept of inherent dignity, Carey most likely does not represent the sort of expansive concept of liberty suggested here.

This conclusion is based upon several factors. First, the Court's recognition of damages for distress caused by the denial of procedural due process does not seem to stem from the view that inherent values constitute, in their own right, liberty interests eligible for due process protection. The Court was not asked to decide this question, because the parties did not appeal the district court's conclusion that summary suspension from public school effected a due process violation. Id. 251 n.5. In fact, the district court's analysis, left undisturbed by the court of appeals, 545 F.2d 30 (7th Cir. 1976), focused exclusively on the substantive nature of the students" interests. See note 190 infra. Second, the Court noted that "[p]rocedural due process rules are meant to protect persons not from the deprivation, but from the mistaken or unjustified deprivation of life, liberty, or property." 435 U.S. at 259. Accordingly, it agreed with the court of appeals (and the parties) that the students would be foreclosed from recovery of any compensatory damages, including those for "hurt feelings," if the school officials could make a post-deprivation showing that the factual predicate supporting suspension had indeed existed. Thus, the individual's ability to assert a claim of compensable injury for distress was wholly dependent upon proof that the deprivation was substantively unjustified. Id. 262-64. 
tional text, and that it ignores what the framers wrote. Critics would likely contend that an analysis focusing on the effect of the act, instead of the nature of the interest, smacks of "Lochnering." 168 After all, it might be said that the Constitution only professes to protect life, liberty, and property from governmental abuse, and that it says nothing about prohibiting the deprivation of due process without due process of law. ${ }^{169}$ Put simply, the critics would suggest that there is no constitutional right to procedural due process.

The critics of a free-standing right to procedural due process would, however, be arguing from a position no more textually compelled than the one herein advanced.170 Moreover, their arguments carry profoundly unsettling implications for the integrity of the relationship between governmental power and individual security that lies at the core of our democratic tradition. Rigid adherence to the Roth-Bishop-Meachum analysis will ultimately weaken, if not completely undermine, the role of the Constitution as the tangible expression of our commitment to the inviolability of innate human dignity and self-worth. ${ }^{171}$ A definition of due process that relies absolutely upon legislatively created rights protected by unchecked legislative will makes the law's respect for human dignity depend solely on a majoritarian political process, which the framers

168 This reference is to the frequently criticized substantive due process analysis previously applied in cases symbolized by Lochner v. New York, 198 U.S. 45 (1905), in which the Court read into the due process clause "an economic theory which a large part of the country [did] not entertain." Id. 75 (Holmes, J., dissenting). The term "Lochnering" was apparently coined by Professor Ely in his powerful criticism of the Court's initial abortion cases. Ely, supra note 6, at 944 .

160 Some permutations of the due process clauses that might allow this methodology to fit more closely into the constitutional language are suggested in Cracks In "The New Property," supra note 69, at 451. (E.g., "No State shall . . . deprive any person of life, liberty, property, or due process of law, without due process of law ...." Id.).

170 See text accompanying notes $312-21$ infra.

171 See Paul v. Davis, 424 U.S. 693, 734-35 (Brennan, J., dissenting).

Professor Dworkin has eloquently expressed this idea as follows:

The institution of rights against the Government is not a gift of God, or an ancient ritual, or a national sport. It is a complex and troublesome practice that makes the Government's job of securing the general benefit more difficult and more expensive, and it would be a frivolous and wrongful practice unless it served some point. Anyone who professes to take rights seriously, and who praises our Government for respecting them, must have some sense of what that point is. He must accept, at the minimum, one or both of two important ideas. The first is the vague but powerful idea of human dignity. This idea, associated with Kant, but defended by philosophers of different schools, supposes that there are ways of treating a man that are inconsistent with recognizing him as a full member of the human community, and holds that such treatment is profoundly unjust.

Taking Rughts SertousLx, supta note 6, at 198. 
knew to be unpredictable, and which we know to be often insensitive to, or unaware of, contemporary bureaucratic abuse. ${ }^{172}$

Furthermore, the imposition of procedural safeguards to protect inherent dignitary values would not raise the same concerns as those that ultimately discredited the Lochnering process. Unlike the old and new substantive due process doctrines, ${ }^{173}$ the suggested approach would create no insurmountable obstacles to the development and implementation of governmental policies. The government would not be foreclosed from terminating, modifying, or otherwise affecting substantive entitlements. It would simply have a duty to do so upon conditions, and in accordance with procedures, that ensure respect for individual dignity. Furthermore, increased costs or administrative burdens associated with added procedural protections would not justify a failure to adopt them, although such considerations might affect the scope or form of legislatively created entitlements. ${ }^{174}$ While viewing such factors as relevant to the question of the degree of protection required, ${ }^{175}$ the Court has generally held them irrelevant to a determination of whether constitutional protections apply at all. ${ }^{176}$ Moreover, arguments against procedural rights because of their expense reflect a form of utilitarianism that ignores the importance of the underlying dignitary values. ${ }^{177}$

\section{Strugturing Procedural Protection Responsive TO INHERENT VALUES}

Because dignitary values play a fundamental role in procedural due process analysis, they must be protected by and enhanced with at least minimally adequate procedural safeguards. Attention will now be turned to the form which those safeguards might take. It

172 See note 144 supra.

173 For an example of contemporary attempts to resurrect substantive due process, see Tushnet, supra note 11 .

174 Cf. Goldberg v. Kelly, 397 U.S. 254, 271-79 (1970) (Black, J., dissenting) (discussing administrative burden created by requirement of due process hearing in welfare benefit termination).

For a more general discussion of the extent to which administrative costs and burdens are relevant to the question of procedural protection, see text accompanying notes 187-98, 275-87 infra.

175 See Goss v. Lopez, 419 U.S. 565, 580-84 (1975).

178 See, e.g., Shapiro v. Thompson, 394 U.S. 618, 633-38 (1969) (invalidating residency requirements in state welfare programs as unconstitutional restraints upon the right to travel; the Court rejected several arguments based on administrative convenience).

177 See TAkTNG Rights SERIousLy, supra note 6, at 199 n.l ("[W]e must treat violations of dignity and equality as special moral crimes, beyond the reach of ordinary utilitarian justification."). See also Baker, Utility and Rights: Two Justifications for State Action Increasing Equality, 84 YALE L.J. 39, $52-53$ n.45 (1974). 
should be restated initially, however, that the underlying concern of inherent dignity is that an individual subjected to deprivatory government action be given a meaningful opportunity to participate in the decisionmaking and/or decision-implementing process at a meaningful time. This opportunity must be provided even when the individual has only a limited substantive stake in the outcome. ${ }^{178}$ The opportunity for personal participation is the best assurance that the individual will understand what is about to happen to her and why, and is the essential prerequisite for satisfaction of the innate need to be treated as a responsible and independent human entity. ${ }^{179}$

\section{A. Some Preliminary Observations About Methodology}

Before attempting to sketch a procedural model sensitive to inherent dignitary values, several observations should be made. First, there is no reason why substantive and inherent values must be treated similarly for purposes of formulating and applying procedural safeguards. Although the two sets of values may often be closely related, ${ }^{180}$ each possesses qualities and addresses concerns that

178 See Formal and Associational Aims, supra note 35, at 132-33. "A substantive stake in the outcome" of a due process hearing can be defined in at least three ways, each reflecting the individual's interest in preventing the implementation of the decision that would deprive her of some interest or entitlement. First, the individual might attempt to dispute the factual predicate upon which the governmental action is premised under applicable statutory or other authoritative criteria. This interest has been the most common, and often the exclusive one referred to in Supreme Court cases; it is generally defined in terms of risk of error, mistake, or erroneous deprivation. See, e.g., Carey v. Piphus, 435 U.S. 247, 259-60 (1978); Mathews v. Eldridge, 424 U.S. 319, 344 (1976).

Second, a hearing might provide the individual with an opportunity to raise a substantive argument against the legitimacy of an application of the statutory standards for disentitlement to her case, even when the parties are in agreement concerning the existence of a factual predicate legally sufficient to justify the government action. See, e.g., Carey v. Piphus, No. 73C2522 (N.D. III. 1975), rev'd on other grounds, 545 F.2d 30 (7th Cir. 1976), rev'd, 435 U.S. 247 (1978) (plaintiff Brisco's procedural due process claim sustained when no dispute existed as to the factual basis underlying his public school suspension).

Third, the individual might have a substantive interest in appealing to the official's statutory discretion to forbear from deprivatory action even when the factual basis authorizing such action is unchallenged; moreover, the individual may utilize a hearing to appeal to the official to disregard her own rules or regulations. See Dixon v. Love, 431 U.S. 105, 114 (1977). As to the general role of discretion in the administrative process, see generally $\mathrm{K}$. Davis, Discretionary Justice (1969).

179 See, e.g., Mashaw, The Supreme Court's Due Process Calculus for Administrative Adjudication in Mathews v. Eldredge: Three Factors in Search of a Theory of Value, 44 U. CEr. L. REv. 28, 49-50 (1976) [hereinafter cited as Calculus for Administrative Adjudication]; Formal and Associational Aims, supra note 35, at 130-31. See also Karst, Foreword: Equal Citizenship Under the Fourteenth Amendment, 91 HARV. I. REv. 1, 8-9 (1977).

180 See note 53 supra. 
are functionally distinct. Of course, it would be difficult to conceive of safeguards that could adequately satisfy the need for personal dignity, unless they also at least minimally fulfill substantive. needs. ${ }^{181}$ However, a process that satisfies substantive needs in ways that ignore our underlying need to be treated fairly would deny our humanity-our unique status as moral beings. ${ }^{182}$ It may be that a single procedural form will have the capacity to satisfy both sets of values, but there is no inherent reason why this must be so. ${ }^{183}$ Consequently, the Court could apply distinct methods of analysis to test the adequacy of existing procedural safeguards (if any) in terms of their responsiveness to each of these sets of values. Accordingly, this section will present a procedural model designed to protect inherent dignitary interests, and will do so on the assumption that such a model need not possess characteristics considered necessary to implement substantive goals. ${ }^{184}$ When the procedures applied to the protection of substantive interests are found unresponsive to inherent dignitary concerns, additional, and perhaps independent, procedural devices could be required. ${ }^{185}$

181 See generally Karst, supra note 179, at 5-11, 59-64.

182 See id. 6-9. See also Summers, supra note 52.

183 The near-optimum model of procedural protection required in Goldberg v. Kelly, 397 U.S. 254 (1970), imposed prior to the deprivation and with substantial safeguards, would serve to protect both substantive and inherent interests. See text accompanying note 242 infra. Whether the post-deprivation administrative procedures held sufficient in Mathews and Dixon or the post-deprivation common law remedies found adequate in Ingraham, are capable of responding to either set of values is less than clear. See notes 255-63 infra \& accompanying text. However, even assuming that the procedures approved in these cases are adequate to ensure against a mistaken or erroneous deprivation, there is no reason to expect them to protect inherent dignitary values. Moreover, there is no evidence that the Court even considered the effect of the procdural safeguards provided by the government in these cases on inherent interests.

184 For a comprehensive discussion of the protections often advanced in support of substantive goals and an analysis of their desirability or utility, see Friendly, supra note 9. See also Memphis Light, Gas \& Water Div. v. Craft, 436 U.S. 1, 12 n.12 (1978).

185 In this regard, one could accept the conclusion that important distinctions in factual issues involved in various administrative contexts might justify considerable flexibility in the formulation of substantively oriented procedural protection, without being compelled to abandon the claim for more constant and inflexible protection for inherent values. Thus, one might accept arguendo the validity of the Mathews Court's distinction between the factual issues involved in the termination of disability benefits and those in the Aid to Families with Dependent Children termination context, Mathews v. Eldridge, 424 U.S. 319, 343-47 (1976); but see Calculus for Administrative Adjudication, supra note 179, at 39-45, and further accept arguendo the proposition that such distinctions mandate fewer pre-termination safeguards designed to reduce the risk of substantive error in the former case than in the latter, without being barred from concluding that Mathews was wrongly decided because it ignored the essential role of pre-termination hearings in the protection of dignitary values. The same proposition would apply to the Court's analysis in Dixon v. Love, 431 U.S. 105, 113-14 (1977). 
A second preliminary observation pertains to the appropriateness of the test used by the Court in determining "what due process is due." This test, first articulated in Mathews $v$. Eldridge, ${ }^{188}$ provides:

[I]dentification of the specific dictates of due process generally requires consideration of three distinct factors: First, the private interest that will be affected by the official action; second, the risk of an erroneous determination of such interest through the procedures used, and the probable value, if any, of additional or substitute procedural safeguards; and finally, the Government's interest, including the function involved and the fiscal and administrative burdens that the additional or substitute procedural requirement would entail. ${ }^{187}$

As applied in the Court's subsequent cases, ${ }^{188}$ this three-pronged analysis has only once led to a conclusion that pre-deprivation procedural safeguards, including a right to personal participation, were constitutionally required. ${ }^{189}$ Further, the test has never been applied to any case in which the Court has expressly included inherent dignitary values in its due process analysis. ${ }^{100}$ Moreover, the Mathews analysis addresses only the extent and degree to which an individual's substantive interests are at stake: the second prong's balancing test is concerned exclusively with avoiding "the risk of an erroneous determination." Thus, the individual's interest in the method of treatment is confined to the question of continued entitlement, even though a procedure's functional utility for minimizing factual errors may well be irrelevant to the promotion of other due process goals. ${ }^{101}$ The Mathews test is unsuitable on even more

186424 U.S. 319 (1976).

187 Id. 335.

188 See, e.g., Memphis Light, Gas \& Water Div. v. Craft, 436 U.S. 1, 17-19 (1978); Board of Curators v. Horowitz, 435 U.S. 78, 86 n.3 (1978); Dixon v. Love, 431 U.S. 105, 112-16 (1977); Ingraham v. Wright, 430 U.S. 651, 675 (1977).

180 Memphis Light, Gas \& Water Div. v. Craft, 436 U.S. 1, 19-22 (1978).

190 Indeed, the only post-Mathews case in which the Court has expressed the view that some sort of dignitary value might be implicated by deprivatory governmental action is Carey v. Piphus, 435 U.S. 247 (1978). Carey dealt with the availability of damages for procedural due process violations. Since the appellant did not dispute the Court of appeals' finding of a due process violation, 435 U.S. at 251 n.5, the Court had no occasion to consider whether inherent dignitary values are entitled to constitutional protection. In fact, given the exclusively substantive focus of the prior cases, it is arguable that respondent Brisco's case was wrongly decided by the lower courts, since there appeared to be no dispute as to the factual predicate upon which the school official's suspension decision was based. See also note 167 supra.

191 Procedural Due Process, supra note 4, at 1517 n.35. 
general grounds. Even if the second prong were eliminated, or were expanded to account for the impact of the threatened action upon dignitary values, the utilitarian balancing of the first two elements against a broadly-defined governmental interest would inevitably dilute or eliminate dignitary protection.

In this respect, utilitarianism is hostile to any theory of due process that treats individual dignity as a serious, operative societal value.192 Aside from its questionable assumption that the societal costs of procedural protection can reliably be predicted, utility theory tends to minimize the value of less quantifiable factors (such as dignity) by setting them off against more easily identifiable and often intuitively more compelling conceptions of the public good. It is one thing to recognize the legitimacy of an individual's claim to a measure of autonomy and integrity, but quite a different matter to respond to such a claim when to do so would create tension with a vague notion of the general welfare. ${ }^{193}$ Moreover, it is difficult to accept the proposition that concepts of individual right and public good are susceptible to principled comparison. ${ }^{194}$ Any analysis based upon such a comparison will be predictably more sensitive to the sheer magnitude of the collective interests at stake.

Finally, it is important to note that the Mathews balancing test presupposes inherent limitations on the parameters of the individual values involved. Measured by this test, the individual's claim to freedom from unfair treatment could only be defined as a "right" in the weak sense. Because these "rights" are made wholly relative to the public good, they can always be overridden or abrogated; such abrogation can be effected with relative ease, especially in those situations for which no clearly articulated and reasonably fixed criteria are readily applicable. ${ }^{195}$

192 For a general critique of the utilitarianism of the Mathews analysis, see Calculus for Administrative Adjudication, supra note 179 , at $47-49$. For a more extensive critique of utility theory in the context of first amendment balancing, see M. Shapiro, Freedom of Speech 102-04 (1966).

193 Cf. Ingraham v. Wright, 430 U.S. 651, 680 (1977) ("But even if the need for advance procedural safeguards were clear, the question would remain whether the incremental benefit could justify the cost.").

194 See, e.g., Procedural Due Process, supra note 4, at 1519-20.

195 One recent example of this proposition is Dixon v. Love, 431 U.S. 105 (1977). In Dixon, the Court based its conclusion that no pre-deprivation hearing was required in part upon a conclusion that extending such hearings to drivers prior to license revocation would unacceptably conflict with "the important public interest in safety on the roads and highways, and in the prompt removal of a safety hazard." Id. 114 (citation omitted). See also Oregon State Penitentiary v. Hammer, 434 U.S. 945, 946 (1977) (Stevens, J., dissenting). Although prior exceptions to the requirement of a pre-deprivation hearing had generally been limited to emergency-type situations, see, e.g. Eving v. Mytinger \& Casselberry, Inc., 339 
Although it is not necessary, in rejecting the Court's balancing approach to procedural protection, to embrace the view that dignitary rights are absolute, such a view is not unattractive. As Professor Ronald Dworkin has written:

The prospect of utilitarian gains cannot justify preventing a man from doing what he has a right to do, and the supposed gains in respect for law are simply utilitarian gains. There would be no point in the boast that we respect individual rights unless that involved some sacrifice, and the sacrifice in question must be that we give up whatever marginal benefits our country would receive from overriding these rights when they prove inconvenient. So the general benefit cannot be a good ground for abridging rights, even when the benefit in question is a heightened respect for law. ${ }^{196}$

It is an essential characteristic of an individual right that it be respected and protected against-and because of-consensual views of convenience and expediency. ${ }^{197}$ If a right as fundamental as that to treatment as a responsible and morally reactive human being is to be diminished at all, it should only be under conditions presenting a substantial and immediate threat to similar rights of others. ${ }^{198}$

\section{B. A Model for Minimal Protection}

For purposes of structuring procedural safeguards minimally adequate to protect inherent dignitary values, the process of deprivatory government-individual interaction can be conceptualized in three distinct stages. The first of these is fact-gathering, which is

U.S. 594 (1950) (summary seizure of mislabeled vitamins); North American Cold Storage Co. v. City of Chicago, 211 U.S. 306 (1908) (summary seizure of food unfit for human consumption); see also Fuentes v. Shevin, 407 U.S. 67, 91 (1972), no such justification was applicable in Dixon. There, the District Court rejected the state's emergency argument, because over one month had elapsed between the date that the statutory conditions allegedly justifying suspension occurred and the date that Love was sent a notice of revocation. See Jurisdictional Statement at A7, Dixon v. Love, 431 U.S. 105 (1977). This point was not addressed in the Supreme Court's opinion. That the governmental interest in summary action could be given the heavy weight apparently accorded it by the Court, on the basis of such a loose definition of the danger to highway safety presented by the factsa danger apparently not viewed as an emergency by the responsible state agencydemonstrates the extent to which individual rights can be diluted in the utilitarian shuffle.

196 Taktvg Rughts Seriouslx, supra note 6, at 193.

197 See generally Procedural Due Process, supra note 4, at 1527. See also Note, Formalism, Legal Realism, and Constitutionally Protected Privacy Under the Fourth and Fifth Amendments, 90 Harv. L. Rev. 945, 986-88 (1977).

198 See note 274 infra. 
triggered either by a normal review process mandated by statute ${ }^{190}$ or by a responsible governmental official's discovery of relevant data. ${ }^{200}$ Its function is to determine the existence vel non of the factual predicate upon which a decision leading to a deprivation must be based. The second stage, that of the decision itself, occurs (at least in theory) after relevant data have been gathered, and represents the application of statutory criteria to that data; where the standards permitting or requiring official action have been satisfied, the judgment is reached that a lawfully mandated or permissible deprivation is in order. ${ }^{201}$ The third stage is implementation: at this point, the decision calling for a deprivation is effected through the termination or modification of a benefit or entitlement.

In the Court's recent procedural due process cases, in which the focus has been exclusively upon formal or substantive values, a conclusion that due process applies has almost invariably ${ }^{202}$ led to the determination that some procedural safeguards must attach during the fact-gathering stage. Because the articulated purpose of procedural safeguards has been limited to the prevention of erroneous or mistaken deprivations, ${ }^{203}$ the logical place for individual participation in the decisionmaking process has been assumed to be at the fact-gathering and evaluation stage; for it is there that the most complete and reliable presentation, illumination, and development of the facts upon which the proposed deprivation must be premised can best be accomplished. ${ }^{204}$ The general rule has been that the Constitution requires some kind of hearing prior to the

180 This type of procedure is generally designed to ensure continued beneficiary eligibility in entitlement programs, such as the Social Security disability scheme involved in Mathews v. Eldridge, 424 U.S. 319, 335-39 (1976).

200 Examples range from a school official witnessing specific acts of a student, see, e.g., Goss v. Lopez, 419 U.S. 565 (1975); Ingraham v. Wright, 430 U.S. 651 (1977); to the receipt of information through a welfare field inspection, see e.g., King v. Smith, 392 U.S. 309 (1968); or the anonymous telephone caller's tip.

201 For a discussion of the administrative process describing these two stages in more detail, see Saginaw Broadcasting Co. v. FCC, 96 F.2d 554, 559-60 (D.C. Cir.), cert. denied sub nom. Gross v. Saginaw Broadcasting Co., 305 U.S. 613 (1938).

202 The only arguable exception to this rule has been Ingraham v. Wright, 430 U.S. 651 (1977), in which the Court concluded that procedural safeguards in advance of the decision and implementation stage were not constitutionally required, ostensibly because post-deprivation (post-corporal punishment in this case) remedies recognized by state law were perceived as sufficient protection against erroneous or unjustified action. Id. 677-78.

203 See text accompanying notes 34-39 supra. (1976).

204 See generally K. Davis, Administrative Law of the Seventmes 241-76 
deprivatory action, ${ }^{205}$ even when the deprivation was perceived as temporary. ${ }^{206}$ Moreover, in those cases in which the Court has refused to impose (additional) pre-deprivation procedural safeguards, it has relied upon the existence of statutorily mandated predeprivation procedures (which are often accompanied by postdeprivation safeguards) as being adequate to protect the substantive values at stake. ${ }^{207}$

In determining the required scope of due process hearings, the Court, once again focusing exclusively upon substantive values, has invariably applied the principle of Cafeteria \& Restaurant Workers v. McElroy, ${ }^{208}$ that " $[\mathrm{t}]$ he very nature of due process negates any concept of inflexible procedures universally applicable to every imaginable situation." 209 Recognizing that traditionally accepted tools for reaching the truth have included the rights to a personal appearance, to confrontation with and cross-examination of adverse witnesses, to compulsory process, and to an unbiased tribunal, ${ }^{210}$ the Court has applied a balancing test to determine which of these tools must be employed in each particular type of deprivatory process. It has first assessed the extent to which each of these tools would contribute to the truth-finding process, and then discounted the value of that contribution against the government's interest in opposing the additional protection. ${ }^{211}$ Accordingly, in those cases in which individuals have successfully claimed additional procedural protections, the results have varied significantly: the protection accorded has ranged from the rather formal requirements of a welfare

205 See Boddie v. Connecticut, 401 U.S. 371,379 (1971). See also Memphis Light, Gas \& Water Div. v. Craft, 436 U.S. 1, 16 (1978) (utility termination); Goss v. Lopez, 419 U.S. 565, 581-83 (1975) (school suspension); Bell v. Burson, 402 U.S. 535, 542 (1971) (driver's license suspension); Goldberg v. Kelly, 397 U.S. 254, 263-65 (1970) (termination of welfare benefits).

206 See, e.g., Fuentes v. Shevin, 407 U.S. 67, 82 (1972) (invalidating prejudgment replevin procedures that allowed private parties to repossess chattels merely by applying for a writ).

207 See Dixon v. Love, 431 U.S. 105, 113-14 (1977); Mathews v. Eldridge, 424 U.S. 319 , 345-49 (1976); Mitchell v. W. T. Grant Co., 416 U.S. $600,616-20$ (1974) (upholding Louisiana's sequestration procedures in summary repossession of personal property purchased under an installment sales contract); Arnett v. Kennedy, 416 U.S. 134, 164 (1974) (Powell, J., concurring).

208367 U.S. 886 (1961).

209 Id. 895 (citations omitted).

210 For a comprehensive cataloging of the elements that have been applied to a determination of the adequacy of a due process hearing, see Friendly, supra note 9, at 1279-95. See also Tobriner \& Cohen, How Much Process Is "Due"?: Parolees and Prisoners, 25 Hastings L.J. 801 (1974).

211 See generally Procedural Due Process, supra note 4. 
termination hearing ${ }^{212}$ to the much less rigid prerequisites mandated in public school suspension cases. ${ }^{213}$

In structuring procedural safeguards designed to respond to inherent dignitary values, it is again useful to focus on the fundamental distinctions between those values and the substantive values addressed in recent cases. The central concern is not with the outcome of the governmental action, but with the processes through which the action takes place. The goal is not to ensure that the government acts according to its substantive rules; nor is it to monitor the wisdom of the rules, to check against mistake, or to guard against the abuse of discretion. Instead, the primary concern is to ensure that the method of interaction itself is fair in terms of what are perceived as minimum standards of political accountability-of modes of interaction which express a collective judgment that human beings are important in their own right, and that they must be treated with understanding, respect, and even compassion. ${ }^{214}$ The

212 Goldberg v. Kelly, 397 U.S. 254, 266-71 (1970) (holding that the pre-termination hearing must include notice and the opportunity to confront and crossexamine adverse witnesses, to present oral arguments, and to obtain counsel).

213 Goss v. Lopez, 419 U.S. 565, 584 (1975) (requiring an "informal give-andtake" between student and disciplinarian). See also Carey v. Piphus, Nos. 73C2522, 74C303 (N.D. Ill. 1975), rev'd on other grounds, 545 F.2d 30 (7th Cir. 1976), rev'd, 435 U.S. 247 (1978). It should be noted that the Court has not been entirely precise in mapping out the contours of pre-deprivation hearings, often leaving that task to the lower courts. Memphis Light, Gas \& Water Div. v. Craft, 436 U.S. 1, 12 n.12; id. 27-29 \& n.10 (Stevens, J., dissenting). This has been especially true when the hearing contemplated is more informal than formal. Compare Craft with Morrisey v. Brewer, 408 U.S. 471, 489 (1972).

214 It is noteworthy that the term "compassion" has been absent from the language used by the Court and commentators in describing due process values. Similarly, the concept of "courtesy" has only recently been included in the Court's procedural due process vocabulary. In Memphis Light, Gas \& Water Div. v. Craft, 436 U.S. I (1978), "courtesy" is used on two occasions. In the Court's opinion, written by Justice Powell, it is noted: "Fundamental fairness, not simply considerations of 'courteous' treatment of customers . . . informs the constitutional requirement of notice and the actual provision of a timely opportunity to meet with designated personnel who are duly authorized to review disputed bills and to correct any errors." Id. 16-17 n.I9 (citation omitted) (emphasis added). This reference to "courtesy" seems at best causal or off-hand, although perhaps intimating that the concept is not irrelevant to the constitutionally prescribed norm. In marked contrast, Justice Stevens' dissent appears to reject the relevancy of courtesy outright: "The Due Process Clause does not guarantee a . . . courteous resolution of every dispute." Id. 25 n.7 (Stevens, J., dissenting). These references to "courtesy" may be the first in the entire history of our procedural due process jurisprudence, and, as in the case of the absence of "compassion," I believe this fact is significant.

Compassion and courtesy may ultimately be no more helpful in particularizing human dignity than other terms often used. But I believe these concepts may offer a fresh and relevant dimension to the inquiry. And although compassion may subsume courtesy, both concepts embrace ideas of sensitivity, concern, and fraternity. Indeed, at least one function of the due process methodology suggested in this Article might be to assure that, at the very least, government will treat its citizens 
fact that the nature and function of these two values are in many ways distinct suggests that approaches taken to ensure their protection may also, at least in part, be divergent. On the other hand, the recognition that they share a broader concern for fairness ${ }^{215}$ informs the approach suggested here. Accordingly, I shall deal with the two basic issues which have provided the touchstone for recent Supreme Court attempts to decide "what process is due"-the questions of timing and of the form of procedural protection.

\section{Timing}

The first relevant question is that of timing: at what point in the process of government-individual interaction should safeguards apply? As discussed above, the typical administrative process preceding a deprivation will consist of three separate stages: factgathering, decisionmaking, and decision implementation. Concerned with the individual's interest in freedom from undue risk of erroneous or mistaken deprivation, ${ }^{216}$ the Court has generally mandated (or found sufficient) some opportunity for notice and hearing prior to the point of decisionmaking. ${ }^{217}$ Although a properly structured hearing occurring at this stage could be sufficient to afford minimal protection to inherent dignitary values, there appears to be no reason why it must be available at this time. The purpose of the procedure under discussion is not to provide an opportunity to supplement or contest the factual record, thus purifying, preventing, or delaying the deprivation decision; instead, it is to assure a measure of participation achieved through revelation, explanation, and reaction. Such participation would be meaningful if offered at any point prior to implementation of the decision, that is, at any time before the actual deprivation. Accordingly, the model could appropriately be interposed after the factual issues have been resolved; if this resolution is adverse to the individual's substantive claims and a decision to act against her has been made, and the degree of participation accorded has been insufficient to protect

with compassion and courtesy, especially when it acts to deprive them of something they regard with value.

215 See text accompanying notes 34-60 supra.

216 See, e.g., Goss v. Lopez, 419 U.S. 565, 579 (1975). ("The Due Process Clause will not shield [a student] from suspensions properly imposed, but it disserves both his interest and the interest of the State if his suspension is in fact unwarranted.")

217 See, e.g., cases cited at note 205 supra. See generally AMrerican ConstITIONAL LAw, supra note 54, at 543-50. 
inherent dignitary values, ${ }^{218}$ she would have a right to further participation before the deprivation could be effectuated.

That the opportunity for participation need not be accorded prior to the decision stage does not represent a de-emphasis on the importance of timing to the model. Rather, it reflects the extent to which substantive and inherent values embrace different interests and illustrates the importance of articulating the distinctiveness of those interests. Indeed, the requirement that a mode of participation be provided prior to a governmentally effected deprivation is crucial in its own right, in that it serves to clarify the role and nature of dignity as a fundamental and independently operative due process value. A post hoc consultation might arguably be adequate to correct mistakes and ameliorate the seriousness of material damage created by the act in question. It cannot, however, compensate for the fundamental role of prior dialogue in the fairness and legitimacy of deprivatory decisions. ${ }^{219}$ In this sense, post-deprivation participation would cast individual consultation as a mere afterthought.

\section{Form}

The second major consideration applicable to structuring procedural safeguards pertains to the form that such protection should assume. The Court has invariably concluded that due process requires "some kind of notice" and "some kind of hearing." 220 As

218 A hearing held prior to the decisionmaking stage, focusing exclusively on substantive matters, might be constitutionally sufficient on substantive grounds, yet inadequate to satisfy inherent dignitary values. See notes 227-41 infra \& accompanying text. In such cases, the model developed in the text should be recognized as an additional requirement, thus creating a need for bifurcated procedures.

The possibility that bifurcated procedures might be required does not conflict with the Supreme Court's dictum in Goldberg that "[d]ue process does not, of course, require two hearings." 397 U.S. at 267 n.14. The legislature would have the option to offer a single hearing structure to protect both substantive and inherent values. Given the modest safeguards proposed to protect the latter values, see notes 220-40 infra \& accompanying text, a single pre-deprivation hearing would very likely be adopted.

219 See Amerucan Constitutionar Law, supra note 54, at 550.

220 See, e.g., Goss v. Lopez, 419 U.S. 565, 579 (I975).

The Court has generally required that the individual receive meaningful and adequate notice of the availability of procedures to which she is entitled. Mullane v. Central Hanover Trust Co., 339 U.S. 306, 314 (1950). Notice must be "reasonably calculated" to apprise the individual of such procedures and to permit her to prepare adequately. Memphis Light, Gas \& Water Div. v. Craft, 436 U.S. 1, 14 (1978). Such notice would be an essential prerequisite to the procedures developed in this section. See id. \& n.15. The notice's timing and content might vary, however, depending upon whether a single procedure is offered to respond to both substantive and inherent values or whether the hearing procedure is bifurcated. In the latter case, notice of the second, explanatory hearing might properly be given 
previously indicated, the Court's approach to determining the elements of due process hearings has been marked by flexibility; the Court has resisted pressure to write a "code of procedure." ${ }^{221}$ Instead, it has tried to tailor procedural safeguards to respond to the values found to be at stake and to reflect the ultimate balance struck between individual and governmental interests. Since the operative values have been defined in purely substantive terms, potential hearing elements have been evaluated in terms of their relevancy in protecting substantively accurate and justified outcomes. ${ }^{222}$ Thus the right to personal and oral participation by the individual in the hearing process has depended upon the Court's perception of the nature of the factual issues at stake. ${ }^{223}$ Similarly, the right to confront and cross-examine adverse witnesses has depended upon the issues involved, and even the character of the witnesses; ${ }^{224}$ the right to counsel or counsel-substitute has depended upon the complexity of the issues involved, as well as the likely sophistication or educational level of the individual to be affected. ${ }^{225}$ Other procedural safeguards have been granted or withheld after a similar analysis of the substantive calculus. ${ }^{226}$

Because a determination of procedural safeguards necessary minimally to protect inherent values does not depend upon their relevance to substantive goals, the Court's prevailing analysis is inapposite. Instead, the suggested approach is based upon the purely nonformal goals of revelation, explanation, and participation that serve inherent values. In order to further these goals even in the most minimal fashion, two basic elements should be required:

closer to the time for which it is set. Moreover, the notice might be less detailed, reflecting the hearing's more limited purpose. In cases where one hearing is provided to respond to both values, notice should be structured so as to provide adequate opportunity to respond to and contest the government's substantive claims.

221 See, e.g., Morrissey v. Brewer, 408 U.S. 471, 488 (1972).

222 Indeed, the crucial importance of this inquiry to the Court's overall approach is reflected in the second prong of the analysis of Mathews v. Eldridge, 424 U.S. 319 (1976). See text accompanying notes 187-91 supra.

223 Mathews v. Eldridge, 424 U.S. $319,343-45$ (1976).

224 Id. See also Wolff v. McDonnell, 418 U.S. 539, 568-69 (1974). The rights to confrontation and cross-examination have also been affected by the environment in which the hearing is held. Id.

225 Id. 569-70.

The Court's emphasis on the role of counsel in helping to delineate the issues and present factual contentions in an orderly manner in Goldberg v. Kelly, 397 U.S. 254,270 (1970), has since been tempered by a reluctance to inject unnecessary adversariness into administrative proceedings and by an increasing concern for the potential costs and delays which would ensue were a right to counsel always guaranteed. See, e.g., Goss v. Lopez, 419 U.S. 565, 583 (1975) (no right to counsel for students facing ten-day suspensions from public school).

226 See generally Friendly, supra note 9. 
the right of the individual involved to participate and her concomitant right of oral response or reaction. ${ }^{227}$

The right to personal participation requires the government to provide the adversely affected individual with the opportunity to meet with a responsible official.228 At this "hearing," which might also be called a "meeting" or "conference" in view of its relative informality, the individual would be entitled to receive an explanation of the nature of the decision taken or to be taken, the time frame in which it is expected to be implemented, and the factual and legal justification upon which it rests or would rest. There are important reasons why the communication of this information to the individual must be effected personally and orally. The central function of the "hearing" is to ensure that the individual does in fact understand the nature, reasoning, and probable impact of the action. Especially in mass justice cases, there may be a substantial risk that written communications of the relevant information will not be understood due, perhaps, to the complexity of the issues, or to the individual's lack of reading and cognitive skills. $^{229}$ Moreover, the personal interaction accompanying a face-

227 The rights to personal and oral participation have not always been viewed as mutually inclusive. In Mathews v. Eldridge, 424 U.S. 319 (1976), the Court found sufficient a pre-termination scheme that restricted Eldridge to an opportunity to review a written summary of the evidence upon which the proposed determination to terminate was based and to respond in writing by way of expression of disagreement or submission of additional evidence. Id. 337-38. Moreover, although Eldridge had an opportunity to review medical reports and other evidence in the agency's case file, he could only do so through a friend or representative. Id. 338 n.18. Thus, although Eldridge was allowed a measure of personal participation in the fact-finding process, under the statutory scheme he was not allowed to participate orally in the pre-termination proceedings.

228 The requirement that the government official be "responsible" does not imply that the hearing would have to be presided over by the secretary of a govvernment agency, the superintendent of schools, or the chief executive officer of the public utility. Instead, it contemplates an opportunity to interact with someone who is duly authorized, by statute, regulation, or policy, to act on behalf of the governmental entity involved. Moreover, the official should be one who would be authorized to respond to substantive claims; that is, to resolve disputes and to correct errors. Cf. Memphis Light, Gas \& Water Div. v. Craft, 436 U.S. 1, 16-17 n.19 (1978). Although the purpose of the hearing is not substantive, if the agency representative lacks the appropriate authority, the hearing will likely seem superfluous. Moreover, an essential aspect of the dignitary value at stake is accountability. It would be chimerical to expect a janitor or clerk to be perceived as accountable for the deprivation.

229 In Goldberg v. Kelly, 397 U.S. 254, 269 (1970), the Court noted that a basic reason for requiring a hearing at which the welfare recipient could personally appear was the recipient's probable lack of educational skills necessary to communicate effectively, coupled with the relative inflexibility of written communications. Although the Court addressed itself to the recipient's ability to substantively affect the decisionmaking process-"to mold his argument to the issues the decisionmaker appears to regard as important," id.-the same concern would pertain to her ability to read and understand a written, post-decision explanatory statement. Such 
to-face meeting is more likely to convey the impression that the individual is not being treated as a mere means to the achievement of a utilitarian end; such treatment would, of course, be hostile to the concept of dignity. 230

The second essential element of a procedure minimally responsive to inherent values is the right to respond or react orally to the information communicated in the explanatory phase. ${ }^{231}$ Although at least one commentator has suggested that such a right should not be applicable to every deprivatory situation, ${ }^{232}$ for the most part even those who have argued for less formality in some hearing contexts have recognized the fundamental importance of allowing oral participation by the individual threatened with deprivatory action. ${ }^{233}$ Without expressly deciding the issue, ${ }^{234}$ the Court has indicated that pre-deprivation oral participation would not necessarily be required in those situations in which it would serve no apparent substantive goal. ${ }^{235}$ But when the concern is with inherent values, a right to oral participation seems essential. ${ }^{236}$ Only through such

statements would be extremely difficult to understand, in that they would probably be printed on standardized forms and might contain only boilerplate "legalese" or routine citation to statutes or regulations. But see Mathews v. Eldridge, 424 U.S. $319,343-47$ (1976) (concluding that the nature of the issues and relevant evidence involved in disability termination cases required only written communication). In this regard, in Memphis Light, Gas \& Water Div. v. Craft, 436 U.S. 1 (1978), the Court's concern for effective communication likely to clearly inform public utility customers of "various levels of education, experience and resources," id. 1563 n.15, of threatened service termination caused it to find the utility's informal notice procedures constitutionally insufficient.

230 See note 32 supra. The interaction generated by mandatory face-to-face meetings may not always be characterized by sincerity and understanding, and to that extent may not enhance the individual's perception of fair treatment. It might be overly cynical to assume, however, that the process will generally be counterproductive, for fairness is a broader concept than courtesy alone. See, e.g., Memphis Light, Gas \& Water Div. v. Craft, 436 U.S. 1, $16-17$ n.19 (1978). In any event, the aura of accountability at least symbolically manifested by the right to interaction should not be dismissed as insignificant.

231 The element of oral participation has traditionally been associated with the concept of a hearing. See, e.g., Davis, The Requirement of a Trial-Type Hearing, 70 HARv. L. REv. 193, 194 (1956) ("A Tearing' is any oral proceeding before a tribunal.").

232 See, e.g., Friendly, supra note 9, at 1281.

${ }^{233}$ See, e.g., K. Davis, Discretronary Justice 119-20 (1969) ("Often a good procedure is to let a party know the nature of the evidence against him and to listen to what he has to say...."). See also Freedman, Summary Action by Administrative Agencies, 40 U. CHr. L. REv. 1, 49-51 (1972).

234 See Goldberg v. Kelly, 397 U.S. 254, 268 n.15 (citing FCC v. WJR, 337 U.S. 265, 275-77 (1949)).

235 Dixon v. Love, 431 U.S. 105, 114 (1977).

236 See Procedural Due Process, supra note 4, at 1517 n.35. ("If, however, due process serves other [inherent] purposes as well . . . procedures such as requiring . . the right to make oral submissions may be useful because they would aid in achieving these other purposes served by the clause.") (citations omitted). 
participation can the individual gain a meaningful understanding of what is happening to her, and why it is happening. Moreover, providing the opportunity to react-to register concern, dissatisfaction, and even frustration and despair-is the best method to promote the feeling that, notwithstanding the substantive result, one has been treated humanely and with dignity by one's government..237

It should be emphasized at this point that the model deliberately excludes from its definition of oral participation many of the rights traditionally associated with adversarial hearings, such as the rights to compulsory process, to confrontation with and cross-examination of adverse witnesses, to representation by counsel, to a written record of the hearing, and even to an unbiased hearing officer. There are two reasons for this exclusion. First, while these protections are principally designed to funnel reliable factual data into the decisionmaking process, the sole purpose of the model is to protect inherent dignitary values, which exist independently of substantive outcomes. ${ }^{238}$ Even if some or all of these excluded elements may be essential in the search for truth, they are not necessarily required to promote inherent values. ${ }^{239}$ In many situations, in order to meet substantive concerns, the Court will have ordered some or all of these procedural protections. When implemented, they may well tend to allay the concerns about inherent dignity raised throughout this Article, even though their sole articulated rationale is to meet substantive needs.

The thrust of the model proposed here, however, is to deal with those situations in which the Court has ordered substantive protections which do not fulfill inherent dignitary needs; or, as will more likely be the case, situations in which the Court has deferred to the

237 This opportunity to react to a potential deprivation in the presence of a responsible official can also serve broader governmental interests. It will likely defuse potential frustration and hostility which might otherwise erupt in socially destructive ways. See text accompanying notes 353-59 infra. Moreover, when a hearing responsive to inherent values precedes the deprivation, the individual might, by appeal to official discretion or otherwise, prevent a deprivation which would be unwise or unfair, see Calculus for Administrative Adjudication, supra note 139, at 39-45, a concededly desirable goal. See also Morrissey v. Brewer, 408 U.S. 471, 484 (1972).

238 See note 39 supra and text accompanying notes 34-60 supra.

239 Indeed, some may even be counterproductive to this purpose. For example, representation by counsel may diminish the personal contact between the individual and government official, detracting from the individual's opportunity to obtain a personally satisfactory explanation and response. See, e.g., Gagnon v. Scarpelli, 411 U.S. 778, 787-88 (1973). Cf. Faretta v. California, 422 U.S. 806, 834 (1975) (holding that a criminal defendant may represent himself at trial because, inter alia, "[ $t]$ he defendant might in fact present his case more effectively by conducting his own defense"). 
legislative conclusions, judged the fact-finding process reliable, and failed to provide any additional substantive safeguards. It is in these latter situations, when even substantively accurate outcomes cannot be assured, that inherent dignitary values are most in need of protection.

Secondly, it cannot be emphasized too often that, just as is the case when the Court sets substantive standards for due process adjudication, the concern here is with finding that bare, minimum level of response or accountability demanded by the Constitution. The specific features of the model are in no sense "graven in stone"; 240 rather, they would be subject to expansion or reinterpretation in light of new data or changing conditions. In this sense, the model is not a "formula," but a tentative balance struck between "respect for the liberty of the individual" and the "demands of organized society." ${ }^{241}$ It provides merely the threshhold, not the skylight, in due process adjudication.

Finally, it might be thought that no amount of solicitude for inherent dignitary values would alleviate the feelings of injustice generated by harsh or inaccurately premised outcomes. Thus, one might argue that it is pointless to protect inherent values in deprivatory contexts so devoid of other procedural protections that they cannot even guarantee substantively accurate or fair results. The argument has a certain plausibility. But its focus is primarily upon improving the fact-finding process, not upon restructuring and legitimating the relationship between the individual and her government. It is my firm belief, and the fundamental premise of this Article, that the interaction proposed by the model has fundamental and independent significance to the individual, regardless of substantive outcomes, in that it forces the government's decisionmakers to confront those adversely affected by its policies, and to treat them as individual human beings. In short, the model is premised upon the belief that even in those situations in which the government acts arbitrarily-for example, when inadequate substantive safeguards yield inaccurate factual evidence, leading to mistaken assumptions, which in turn produce substantively unfair results-the individual retains the right to be informed, in the most direct manner, that her government does act arbitrarily, as well as the right to react to such treatment.

240 Wolff v. McDonnell, 418 U.S. 539, 572 (1974).

241 Poe v. Ullman, 367 U.S. 497, 542 (1961) (Harlan, J., dissenting), quoted in relevant part in text accompanying note 107 supra. 


\section{Applying the Model}

Applying this hearing model to some of the Court's recent procedural due process cases may help to clarify its operation and demonstrate its effect. For example, the procedures ordered by the Court in Goldberg $v$. Kelly ${ }^{242}$ more than satisfy the requirements of the model. The pre-termination welfare hearing there required provided the recipient with a right personally and orally to participate in the decisionmaking process well in advance of the implementation of deprivation. The same could be said for the conclusion reached in Arnett $v$. Kennedy. ${ }^{243}$ Although the Court held that a fully adversarial hearing, similar to the one ordered in Goldberg, was not required prior to Kennedy's dismissal from government employment, the applicable statutory procedure provided for advance written notice of the proposed discharge, the right to respond to the charges both orally and in writing, and the right to appear personally before a responsible official with authority to make the final decision. ${ }^{244}$

Several other due process cases have resulted in the imposition or approval of pre-deprivation procedures at least minimally consistent with the model set forth above. They include: Wolff $v$. $M c D o n n e l l,{ }^{245}$ in which the Court required, as a prerequisite to prison disciplinary action, that prison authorities provide the affected inmate with written notice of the charges, and the opportunities for personal appearance and oral participation in a hearing

\section{U.S. 254 (1970). \\ 243416 U.S. 134 (1974).}

244 Id. 170 (Powell, J., concurring). Although Arnett v. Kennedy, 416 U.S. 134 (1974), has been subjected to extensive scholarly criticism, see, e.g., Comment, Fear of Firing: Arnett v. Kennedy and the Protection of Federal Career Employees, 10 HAnv. C.R.-C.L. L. Rev. 472 (1975), most of that has been directed to the inadequacy of the Court's analysis in terms of protecting substantive values. One of Arnett's most controversial aspects was the Court's failure to require that pretermination process be presided over by an impartial hearing examiner. See generally id. 495-97. Although such neutrality might be essential for puposes of reliable and unbiased factual and substantive determinations, see, e.g., Tumey v. Ohio, 273 U.S. 510 (1927), it does not seem fundamental to the inherent dignitary concerns of participation and revelation. There could well be situations in which the individual would achieve a greater understanding of the entire decisionmaking process and a greater perception of fairness where the offcial on the other side of the desk is known to her on a personal level. The possibility that such a meeting might occasionally become an acrimonious confrontation does not necessarily undermine its value; it still might, in fact, have beneficial aspects. See note 333 infra. 
before a responsible official committee; ${ }^{246}$ Goss $v$. Lopez, ${ }^{247}$ which held that a public school student facing possible suspension has the right to oral or written notice of the charges against him, the right to receive an explanation of the evidence against him, and the right to present his side of the story before the suspension can be imposed; ${ }^{248}$ and Memphis Light, Gas \& Water Division v. Craft, ${ }^{249}$ in which the Court held that before a government-owned utility company can terminate customer service it must provide notice of the impending termination, an opportunity for the customer to meet with responsible personnel, and the chance to participate orally at such a meeting. ${ }^{250}$

The New York statutes establishing conditions for removal of a child from foster family care, upheld in Smith $v$. Organization of Foster Families, ${ }^{251}$ also comport with the model, at least with respect to the foster parents' due process claim. The statutes involved provided pre-removal notice to the foster parents, as well as an opportunity to request a conference with social service officials, who were obligated to provide a statement of reasons for the proposed action. ${ }^{252}$ The foster parents were also accorded the right to submit reasons in opposition to the threatened removal; ${ }^{253}$ because the statute does not expressly restrict their participation to a written form, it would appear that oral reaction and response were contemplated. Moreover, once the request for a conference had been received by the agency, the child could not be removed from the foster home until after the conference had been held and a decision rendered. ${ }^{254}$

$246 I d$. 566-67 \& n.17. The fact that the Court refused to recognize a universal right to confrontation and cross-examination might be properly criticized, but on substantive grounds. Id. 584-90 (Marshall, J., concurring in part and dissenting in part).

247419 U.S. 565 (1975).

248 Id. 581-84. It should be noted, however, that to the extent that the Court's opinion recognized the student's right to explanation and oral participation as contingent upon the student's denial of the charges, $i d$., it would be unacceptable on inherent dignitary grounds. In this respect, the District Court's holding in Carey v. Piphus, 435 U.S. 247, 251 \& n.5 (1978)-that Goss requires schools to provide additional, more formal procedures to students facing possible suspensions of more than ten days-was correct as it pertained to both plaintiffs, even though plaintiff Brisco did not challenge the factual predicate underlying his suspension.

249436 U.S. 1 (1978).

250 Id. $16-19$.

251431 U.S. 816 (1977).

252 See 18 N.Y.C.R.R. $\$ 450.10$ (a) (1976), discussed in Smith v. Organization of Foster Families, 431 U.S. 816, 829-32 (1977).

25318 N.Y.C.R.R. $\$ 450.10(a)$ (1976).

254 The Smith case does, however, raise an important question not previously addressed: regardless of the adequacy of procedural protection accorded others 
Conversely, a number of the Court's recent decisions are clearly inconsistent with the model. For example, the recipient of disability benefits in Mathews $v$. Eldridge ${ }^{255}$ was given no opportunity

directly affected by a governmentally inflicted deprivation, when is the effect on any specific individual sufficient to trigger an independent entitlement to the participation contemplated by the model?

In one sense, this issue might be regarded as purely a question of standing, raising traditional queries concerning injury in fact and personal stake in the outcome. See generally Amertcan Constiturtonar Law, supra note 54, at 79-101; Scott, Standing in the Supreme Court-A Functional Analysis, 86 Harv. L. Rev. 645 (1973). But on a broader level, an examination of this issue provides a clearer insight into the inherent values which lie at the core of the due process guarantee.

In Smith, the district court had concluded that a pre-removal hearing should be provided as a matter of course-not merely at the foster parents' request-because the interests of the foster parents and the child might not be coextensive. Organization of Foster Families v. Dumpson, 418 F. Supp. 277, 284-85 (S.D.N.Y. 1976), rev'd sub nom. Smith v. Organization of Foster Families, 431 U.S. 816 (1977). For the Supreme Court's appraisal of that aspect of the district court's conclusion, see 431 U.S. at 850-52. The district court, in effect, found that the child herself was inherently threatened with potential deprivation if the removal was effected, and therefore should be entitled to due process protection as a personal right. In the district court's view, the purpose of the protection was to ensure that the substantive grounds for removal existed, or in other words, that the removal was in the child's best interest. $418 \mathrm{~F}$. Supp. at 285-86.

After applying the substantively focused, three-pronged balancing test of Mathews v. Eldridge, 424 U.S. 319 (1976), the Supreme Court disagreed. It viewed the assumed liberty interest at stake as belonging to the foster family as a unit, and noted the intuitive difficulty in a conclusion that a foster child is actually deprived of anything where the foster parents do not care enough to contest the threatened removal. Id. 850-51. Although the Court "assumed" that some preremoval consultation with the child would be desirable, it concluded that due process "does not require that the child or an appointed representative must be a party ... in all pre-removal hearings." Id. 852 (footnote omitted).

As a general rule, common sense might suggest that foster children, whose foster parents are unwilling to fight to keep them, would not suffer greatly from a forced removal from the foster home. In this sense, it may be impossible to assess the extent, if any, of the deprivation felt by the child. But in a broader sense, it seems certain that a move from one foster placement to another would be a profoundly traumatic experience, especially for a young and impressionable child. The confusion and disruption inherent in such a move could be substantial, with longterm negative effects. This might especially be true when the removal occurs for reasons, or under conditions, not easily or clearly understood by the child. Accordingly, the Court's off-hand rejection of the child's independently premised due process claim may have been inappropriate. Given the potential impact of removal on the child, with its attendant implications for the child's interest in being treated with dignity, it would seem that the child herself should have the right to the personal participation and revelation contemplated by the model developed above.

Concededly, there may be risk of increased tension or anxiety associated with such participation; but this risk should be insufficient to preclude the child's participation at the hearing, unless a clear showing of probable damage to the child's psychological or physical health can be made. Alternatively, the child's hearing could be structured to preclude the factors creating such a risk: if the foster parents themselves create the risk, they can be excluded from the hearing.

The Supreme Court's conclusion that the natural parents have no independent right to participation, 431 U.S. at 851 , causes fewer problems. Although the natural parents might well have a continuing emotional stake in their child's welfare, the effect upon them of the child's removal from one foster home and placement in another seems less direct. 
to meet with a responsible agency representative prior to benefit termination. ${ }^{250}$ In Dixon $v$. Love, ${ }^{257}$ the driver's licensee was denied a similar opportunity. ${ }^{258}$

Similarly, the summary corporal punishment approved in Ingraham $v$. Wright ${ }^{259}$ fails to comport with the procedural model suggested here. Prior to being paddled, the public school student in Ingraham was given neither an explanation of the reasons for his punishment, nor a chance to react orally to the decision-except by yelling out in pain during its implementation. After conceding that the student had a "strong interest in procedural safeguards," the Court defined that interest solely in terms of minimizing "the risk of wrongful punishment" and providing for the "resolution of disputed questions of justification." 280 The Court concluded that state common law and statutory post-punishment remedies and criminal sanctions, coupled with the "openness of the school environment," were sufficient to "afford significant protection against unjustified corporal punishment." ${ }^{261}$ The student's interest in "a perception of fair treatment" was summarily dismissed, through utilitarian balancing, in a footnote. ${ }^{262} \mathrm{Mr}$. Justice White's dissent, in persuasively contending that state law remedies were inadequate to provide meaningful substantive protection, noted that a postpunishment lawsuit could not undo the infliction of physical pain,

255424 U.S. 319 (1976).

256424 U.S. at 345-46; see note 227 supra.

257431 U.S. 105 (1976).

258 Id. 114. The fact that the licensee had ample opportunity to contest each traffic violation which, cumulatively, triggered the suspension is not dispositive for inherent dignitary purposes. The decision to suspend was statutorily entrusted to the Secretary of State, rather than to a state judge presiding over a single offense. In this sense, only the Secretary (or his designate) could be deemed the "responsible official." See note 228 supra.

259430 U.S. $651,672-82$ (1977).

$260 I d .676$.

$261 \mathrm{Id} .678$.

262 Id. 681 n.52. Interestingly, the Court seems to have used the dignitary interest as an argument against requiring pre-punishment process, noting that "[t]he effect of interposing prior procedural safeguards may well be to make the punishment more severe by increasing the anxiety of the child." Id. 681 n.51. Although a lapse of a considerable period of time between the punishable conduct and punishment itself might theoretically exacerbate the perceived severity of the punishment, the hearing model suggested here could be quickly and effectively provided. Moreover, the argument that a brief wait will enhance the severity of the punishment fails to account for the potential substantive effect of a hearing in obviating the need for punishment. It also assumes that the value of the participation and explanation inherent in such a hearing will be outweighed by the speculative potential of increased anxiety. If dignitary values are as fundamental as I have argued, this assumption is questionable at best. 
which he saw as "final and irreparable." ${ }^{263}$ Surely, the injury to inherent dignitary values, once infringed, is equally difficult to redress.

The medical student's expulsion from school, upheld in Board of Curators v. Horowitz, ${ }^{264}$ raises similar problems. In Horowitz, the Court found the university's pre-expulsion procedures-involving repeated evaluations of the student's performance by a studentfaculty Council on Evaluation, a faculty Coordinating Committee, and a panel of seven practicing physicians-to provide greater procedural protection than the Constitution required. ${ }^{265}$ Although these procedural steps may arguably have been sufficient to adequately respond to Ms. Horowitz's substantive interests in defending "her academic ability and performance," 286 they were clearly insufficient in several respects to respond to inherent dignitary values. First, Ms. Horowitz apparently was not permitted to appear before either the Council or the Committee. ${ }^{267}$ Moreover, none of the members of the three reviewing bodies were "responsible" officials, because their judgments were only recommendations, subject to approval by the medical school's dean. ${ }^{268}$ Although their determinations may have been impartial, they were not necessarily authoritative or final. Furthermore, her only chance to reply to the decision of the responsible official, the dean, was in writing. ${ }^{269}$

The Court created further conceptual problems by distinguishing between dismissals based upon misconduct and those, like Ms. Horowitz's, which were based upon "academic" failure. For the former category, it prescribed the Goss ${ }^{270}$ due process protections, after noting that " $[t]$ he requirement of a hearing, where the student could present his side of the factual issue, could under such circumstances, 'provide a meaningful hedge against erroneous ac-

203430 U.S. 651, 695 (1977) (White, J., dissenting). But see Carey v. Piphus, 435 U.S. 247 (1978) (absent proof of actual injury, students wrongfully suspended from school may recover only nominal damages for violation of their due process rights).

264435 U.S. 78 (1978).

$265 I d .85$.

$288 \mathrm{Id}$.

207 Without expressly stating that Ms. Horowitz actually was excluded from the meetings of these two reviewing bodies, the Court noted, "Students are not typically allowed to appear before either the Council or the Coordinating Committee on the occasion of their review of the student's academic performance." 435 U.S. at 80.

268 Id.

289 Id. 82.

270 Goss v. Lopez, 419 U.S. 565 (1975). 
tion." " 271 However, it viewed dismissal decisions based upon academic grounds as "by [their] nature more subjective and evaluative than the typical factual questions presented in the average disciplinary decision." 272 Consequently, after concluding that no substantive interests were at stake, and mindful of the institutional limitations upon its power, the Court refused to prescribe any meaningful due process safeguards. The opinion once again illustrates that the Court's due process analysis is exclusively, and blindly, concerned with substantive issues. In a society in which status and economic advancement often depend upon educational achievement, the Court ignored the potentially catastrophic effect that academic judgments can have on the student's capacity for self-esteem and self-respect. Moreover, because an academic dismissal may indeed be predicated upon more "subjective and evaluative" criteria than is one for misconduct, unless the dismissed student is accorded the minimal participation contemplated by the procedural model developed in this Article, she will likely fail to comprehend and accept the decision.273

\section{Some Reflections on the Model}

The procedural model sketched in this section suggests a number of issues pertinent to its viability. Principally, they concern questions of convenience, burden, and cost. A few brief, and admittedly preliminary, responses to some of these issues would therefore be appropriate.

The first issue concerns the workability of the model: can it be implemented across the entire spectrum of deprivatory actions taken by federal, state, and local agencies and officials? As was previously noted, a broadly defined governmental interest in convenience and expedience should not determine whether procedural safeguards are suitable for protecting dignitary values. ${ }^{274}$ It is appropriate, how-

271435 U.S. at 89 (quoting Goss v. Lopez, 419 U.S. 565, 583 (1975)).

$272 I d .90$.

273 See id.

274 See text accompanying notes 191-98 supra. Although a utilitarian analysis that balances the individual right to dignity (and the concomitant right to procedural protection) against a generalized majoritarian benefit in disregarding that right is inappropriate, it has elsewhere been contended that a more narrowlyconfined determination of the extent to which the individual right conflicts with competing individual interests of others would not be so. See generally Procedural Due Process, supra note 4. Concluding that procedural rights are not absolute, the authors of that Note suggest that "[t]he central question is whether the individuals in the class benefited by withholding the procedures have what can fairly be described as a "right' to the benefit" id. 1528. The relevant "class" would have to be "determinate or consist of identifiable individuals," id. 1529; the "competing right" would have to be capable of being "described as an entitlement to either liberty 
ever, to consider the potential impact of the model on governmental processes and institutions; if the model should prove impossible to implement, or unmanageable, alternative methods of protection might be more desirable.

In this regard, it is useful to point out that the model will have only a minimal effect, in terms of administrative burden and delay, upon the government's ability to carry out substantive programs, especially essential ones. Indeed, the model will scarcely threaten such programs at all. The additional procedures suggested above are quite informal. The model does not contemplate the provision of an extensive notice period. ${ }^{275}$ Nor does it require extensive time for argument, since its function is not substantive; in most cases, the hearing could be completed in a relatively brief period of time.278 Any additional burdens imposed by such hearings would be slight, and the hearings themselves would not preclude the government from acting effectively in the public interest. Indeed, the existing time frame for deprivatory action under many governmental programs would be unaffected by the model's requirements, because few governmental decisions to take deprivatory action are made and implemented simultaneously. ${ }^{277}$ One possible exception might be in

or property," id. 1530; and those basing competing claims on such rights would have to have standing, in the traditional sense, to assert them. Id. $1529-30$ \& n.80. Concededly, this analysis seems less objectionable than a broader utilitarian calculus; it would be difficult to conceive of a situation that, when analyzed this way, would lead to the conclusion that the minimal procedural rights implicit in this Article's model would be required to yield to the "rights" of others. But even such a narrowly-structured utilitarianism unacceptably threatens the integrity of dignitary values. See id. 1530 n.82 ("Even when the rights of others are unavoidably in conflict with an individual's right to due process, it is not inevitable that the due process right must be the one to be limited.") (emphasis added). Only a clear showing that the denial of dignitary rights is necessary to preserve the life, safety, or dignitary rights of other specified and identifiable individuals should be suffcient to justify summary action.

275 See note 220 supra.

276 Of course, if the nature of the substantive issues to be decided calls for a more expansive pre-termination hearing, which includes the elements contemplated by the model, the time period would generally be longer. See, e.g., cases mentioned in text accompanying notes 242-54 supra. But the potential burdens associated with such a hearing would already have been figured into the Court's due process calculus. See the balancing test of Mathews v. Eldridge, 424 U.S. 319, 334 (1976), which appears in text accompanying note 187 supra.

277 See, e.g., Memphis Light, Gas \& Water Div. v. Craft, 436 U.S. 1, 18-19 n.22 (1978) (noting that since the public utility already provided at least a 30 -day period between the mailing of the bill and the actual termination of service, informal pretermination procedures consistent with this model would be unlikely to materially delay payment). Similarly, in Dixon v. Love, 431 U.S. 105 (1977), the Illinois Secretary of State did not act to revoke Mr. Love's driver's license until over two months had elapsed since the conviction giving rise to the Secretary's action, Brief for Appellee at 26-27, during which period an informal hearing could surely have been offered. See also id. 44-52 (listing numerous states that require hearings prior 
the case of disciplinary decisions made in institutional settings. However, the pre-punishment procedures already required in correctional and mental institutions ${ }^{278}$ provide adequate protection for inherent dignitary values in most disciplinary contexts. ${ }^{27 \theta}$ Similarly, Goss already provides adequate protection for public school students facing possible suspensions of up to ten days. To the extent that the Court has viewed informal hearings as unduly burdensome to other modes of student discipline, ${ }^{280}$ it has relied upon untested speculation concerning the effect of such hearings on teachers' willingness to discipline. ${ }^{281}$

Another consideration affecting the model's viability is its cost. Although the Court has stated that the potential costs will not be dispositive of whether a particular procedural device is constitutionally required, ${ }^{282}$ it has accepted cost as one relevant factor in its balancing process. ${ }^{283}$ The costs of the hearing model under consideration, however, would be relatively insubstantial. First, the hearings themselves do not contemplate a cadre of professional magistrates; nor do they involve the expenses associated with the preparation of written records, payment and preparation of witnesses, and the award of attorneys' fees. Secondly, there is little risk that the hearing requirement would impose substantial financial burdens upon entitlement programs such as welfare by requiring the interim payment of benefits prior to their ultimate termina-

to suspension or revocation of motor vehicle operation licenses). Even the Social Security Administration's benefit-termination procedures challenged in Mathews v. Eldridge, 424 U.S. 319 (1976), contemplated the lapse of a substantial period of time between the initial review of continued eligibility and final termination during which an informal hearing could be provided, id. 335-39. Conceding arguendo the government's contention in Mathews that a requirement of fully adversarial hearings, similar to those imposed in Goldberg v. Kelly, 397 U.S. 254 (1970), would "severely tax the capacity of the Social Security Administration to conduct an effective disability program," Petitioner's Brief for Certiorari at 8, the argument would clearly not be valid if addressed to the hearing model under consideration.

278 See, e.g., Wolff v. McDonnell, 418 U.S. 539 (1974).

279 See note 246 supra \& accompanying text. But see Montanye v. Haymes, 427 U.S. 236 (1976); Meachum v. Fano, 427 U.S. 215 (1976).

280 See Ingraham v. Wright, 430 U.S. 651, 680-81 (1977).

281 See id. 700 (White, J., dissenting).

It is worth noting that the judicial remedies relied upon as adequate substitutes for pre-deprivation hearings in Ingraham are perhaps more likely to deter otherwise desirable official conduct than are more informal administrative procedures. See, e.g., Wilkinson, supra note 91, at 67-68.

282 Mathews v. Eldridge, 424 U.S. 319, 348 (1976).

283 Id. See also Smith v. Organization of Foster Families, 431 U.S. 816, 851 (1977); Gagnon v. Scarpelli, 411 U.S. 778, 788 (1972); Richardson v. Perales, 402 U.S. 389, 406 (1971). See generally Comment, Entitlement, Enjoyment, and Due Process of Law, 1974 Duke L.J. 89, 121. 
tion. ${ }^{284}$ In those situations (such as the termination of welfare benefits) in which a full adversarial hearing is already required for substantive reasons, ${ }^{285}$ the model would impose no additional costs. In other situations, in which substantively-oriented procedures must be supplemented with those dictated by the model, the hearing could occur immediately after the deprivatory decision had been reached, 288 thus minimizing the likelihood that substantial sums would be paid to those whose entitlement no longer exists. Moreover, procedures are generally available for recoupment of benefits improperly received. ${ }^{287}$

The model also raises a broader concern which may be more difficult to resolve. Aside from the issues of administrative convenience, burden, and cost, it is appropriate to consider whether the model's protection is needed in every context in which the government acts to deprive an individual of an entitlement or something to which a claim of right attaches. Conceding that the RothBishop-Meachum analysis sweeps too broadly in immunizing governmental conduct from constitutional scrutiny, it might still be contended that a requirement of even modest procedural safeguards before every official deprivation would represent judicial overprotectiveness and would lead to counterproductive results. ${ }^{288}$ This point of view has found strong support in the Burger Court, particularly in the opinions of Mr. Justice Powell. 2s9 Moreover, such a view is implicit in the apparently unanimous agreement by

284 For an extensive response to the cost argument which is generally applicable here, see Richardson v. Wright, 405 U.S. 208, 223-26 (1972) (Brennan, J., dissenting).

285 See, e.g., cases discussed in text accompanying notes 221-25 supra.

286 It is true that the model contemplates a substantial increase in the total number of hearings required in the administration of many entitlement programs, thus raising practical questions concerning an agency's ability to schedule hearings swiftly. It seems unlikely, however, that deprivation decisions made by an agency would be so disproportionately concentrated at any given time that reasonable promptness in the scheduling of hearings could not be achieved. See generally Richardson v. Wright, 405 U.S. 208, 225 (1972) (Brennan, J., dissenting).

287 See, e.g., 42 U.S.C. $\$ 404$ (a) (1976); 20 CFR $\$ 404.502$ (1978) (directing HEW Secretary to require refund or future set-off of overpayments of old Age, Survivors and Disability Insurance benefits).

288 See, e.g., Wilkinson, supra note 91 , at 73-75. Professor Wilkinson's arguments against procedural protections for lesser deprivations involving mere "psychological discomfort" are partially based upon the view that such injuries may have the salutary effect of preparing us for the greater adversities inevitable in life. It may be true that much of life is inevitably cruel, but while government may have no affirmative obligation to shelter us from privately inflicted cruelty, it seems axiomatic that it ought not be permitted to participate actively in individual despair.

280 See, e.g., Goss v. Lopez, 419 U.S. 565, 584 (1975) (Powell, J., dissenting). See also Memphis Light, Gas \& Water Div. v. Craft, 436 U.S. 1, 22 (1978) (Stevens, J., dissenting). 
the Justices that some deprivations of liberty and property interests are so inconsequential that they need not be considered in any constitutional calculus. ${ }^{290}$ In recent cases, this concern has led the Court to defer to legislative judgments concerning pre-deprivation safeguards, rather than to face the tasks of drawing fine lines and resolving questions of degree. ${ }^{291}$ But for several reasons these concerns seem unwarranted.

First, fears of "constitutionalizing" administrative processes are born, at least partially, of a legitimate concern that the often necessary and generally unpleasant task of deprivation be no more complex than it need be. The adversarial nature of the traditional formal hearing may indeed create more hostilities and anxieties than it relieves, while not assuring any substantive rewards.292 The role of the hearing model suggested here, however, is not to define the difference in the parties' positions, but to focus on their shared purpose of achieving mutual understanding, if not harmony. Its non-adversarial nature may indeed lead to reduced anxiety and hostility. Contrary to $\mathrm{Mr}$. Justice Powell's reservations, ${ }^{293}$ minimal procedural regularity may be the best means available to inculcate and enhance citizen respect, both for government and for self.

Second, the argument that a deprivation can be so inconsequential that it fails to undermine important constitutional values must be assessed in light of all the values at stake. In a relative sense, it may be natural to de-emphasize the impact of the most minor substantive injuries, especially when they are dwarfed by the more massive deprivations inherent in a society in which so many are dependent upon government largess. But it is more difficult to discount the damage to dignitary values inflicted by governmental action. That damage, caused by the unexplained and unaccountable actions of a faceless government, can far exceed the tangible harm inflicted. Moreover, it causes a kind of two-edged injury that undercuts the very legitimacy of all government action. ${ }^{294}$ Finally,

290 See, e.g., Ingraham v. Wright, 430 U.S. 651, 674 (1977). ("There is, of course, a de minimis level of imposition with which the Constitution is not concerned."); Goss v. Lopez, 419 U.S. 565, 576 (1975) ("[A]s long as a property deprivation is not de minimis, its gravity is irrelevant to the question whether account must be taken of the Due Process Clause.").

291 See, e.g., Board of Curators v. Horowitz, 435 U.S. 78, 86 \& n.3. But see Memphis Light, Gas \& Water Div. v. Craft, 436 U.S. 1 (1978) (imposing predeprivation procedures upon a state-regulated utility company). senting).

202 See, e.g., Goss v. Lopez, 419 U.S. 565, 594-95 (1975) (Powell, J., dis-

293 Ingraham v. Wright, 430 U.S. 651, 681 n.52 (1977) (quoting Wilkinson, supra note 91 , at 71-72).

294 See text accompanying notes 354-59 infra. 
a constitutional principle permitting government to ignore the consequences of its actions as long as massive injury does not ensue effects a quantification of the human spirit which diminishes us all. ${ }^{295}$

\section{Reconciling Responsive Due Process Methodology With} the Concern for Legitimacy in Judicial Review

\section{A. Problems of Language, Discretion and Legitimacy}

The methodological alternatives to the Roth-Bishop-Meachum model of procedural due process would, as I have argued, be more responsive to inherent dignitary values, in that they would recognize a right to be free from arbitrary governmental action. But ultimately, a constitutional methodology must be measured in terms of its congruence with the underlying premises of judicial review. ${ }^{296}$ These premises generally require that the exercise of judicial power -especially that of federal judicial power, because the federal courts are relatively insulated from popular pressure by Article III's guarantees of lifetime tenure and salary-be reconciled with the more majoritarian political institutions in our society. Accordingly, the power to negate decisions made by the more politically responsive branches of government is imbued with a sense of caution; its exercise is often thought appropriate only when the underlying authority for action is clear. ${ }^{297}$ Because such authority emanates from the Constitution itself, ${ }^{298}$ the Supreme Court and, of course,

205 This realization is implicit in Carey v. Piphus, 435 U.S. 247 (1978), in which the Court concluded that, where applicable, "the right to procedural due process is "absolute," notwithstanding "the merits of a claimant's substantive assertions ...."Id. 266. The Court apparently recognized that procedural rights are per se valuable in a society that takes each of its members seriously, and that this is true even where a deprivation imposes no other "actual injury" that is objectively manifested and provable by traditional means. Id. Because the Court has already conceded the importance of process qua process, even if only nominally or symbolically, it is even more difficult to explain how substantively minor deprivations can be perceived as constitutionally irrelevant.

296 See generally P. Brest, Processes of Constitutional Decistonmaking, Cases and Materials 956-86 (1975). See also Bork, Neutral Principles and Some First Amendment Problems, 47 InD. L.J. 1 (1971); Linde, Judges, Critics, and the Realist Tradition, 82 YArE L.J. 227 (1972).

207 See City of New Orleans v. Dukes, 427 U.S. 297, 303-04 (1976) (deferring to legislative wisdom in upholding a "local economic regulation" against an equal protection challenge, id. 303); Thayer, The Origin and Scope of the American Doctrine of Constitutional Law, 7 HaRv. L. Rev. 129 (1893). See also notes 1-6 supra \& accompanying text.

298 Marbury v. Madison, 5 U.S. (1 Crançh) 137 (1803). 
the inferior federal courts, have generally adhered quite strictly to the textual directives of that document. ${ }^{209}$

These premises of judicial review, however, have seldom been regarded as precluding at least some flexibility in constitutional adjudication. 300 When the text has been viewed as unclear or inconclusive, the Court has referred to a number of non-textual sources, if only as guides to an understanding of the framers' intent. $^{301}$ A primary non-textual source has been the legislative history of the provision in question..$^{302}$ Where the text or legislative history has been found inconclusive, the Court has found constitutional rights or values in areas quite removed from the text, including the design of the Constitution, ${ }^{303}$ implicit requirements derived from express provisions, ${ }^{304}$ penumbras and emanations of express provisions, $^{305}$ and enlightened public opinion. ${ }^{306}$ Some rights, not explicitly protected by the Constitution, have nevertheless been ac-

299 See, e.g., San Antonio Independent School Dist. v. Rodriguez, 411 U.S. 1, $32-33,35-36,42-44$ (1973) (upholding Texas' system of financing public education, after concluding that education is not among the rights afforded either explicit or implicit protection under the Constitution); Lindsey v. Normet, 405 U.S. 56, 74 (1972) (" $[T]$ he Constitution does not provide judicial remedies for every social and economic ill. We are unable to perceive in that document any constitutional guarantee of access to dwellings of a particular quality ...."). See also H. BIACK, $\AA$ Constifutionat Fatte (1968).

300 See Grey, supra note 1, contending that the Court has seldom viewed itself as bound by a "pure interpretive model" in constitutional adjudication, and endorsing the broader view of judicial review which recognizes the Court as "the expounder of basic national ideals of individual liberty and fair treatment, even when the content of these ideals is not expressed as a matter of positive law in the written Constitution." Id. 706.

301 For a general treatment of the role of the framers' intent in constitutional decisionmaking, see P. BREST, supra, note 296, at 139-71.

It is, of course, inevitable that even a literal reliance upon the framer's intent will often be inconclusive in resolving constitutional questions which, due to social evolution, could not have been anticipated by the framers. But, as Professor Ely has noted, "the Court is entitled, indeed . . . it is obligated, to seek out the sorts of evils the framers meant to combat and to move against their twentieth century counterparts." Ely, supra note 6, at 929. Cf. Katz v. United States, 389 U.S. 347 (1967) (fourth amendment's warrant requirement applicable to electronic eavesdropping).

302 See, e.g., Williams v. Florida, 399 U.S. 78, 86-103 (1970) (upholding a state law which provides for six-member juries in noncapital criminal trials). 303 See, e.g., Moore v. City of East Cleveland, 431 U.S. 494, 544 (1977) (White, J., dissenting); Harper v. Virginia Bd. of Elections, 383 U.S. 663 (1966); Edwards v. Habib, 397 F.2d 687, 696-98 (D.C. Cir. 1968). See generally C. BLACK, Structure and RELationship IN ConstTrutional LaW (1969).

304 See, e.g., NAACP v. Alabama, 357 U.S. 449 (1958) (right of association). See generally Ely, supra note 6 , at 935-37.

305 See, e.g., Griswold v. Connecticut, 381 U.S. 479 (1965) (right to privacy). See generally Kauper, Penumbras, Peripheries, Emanations, Things Fundamental and Things Forgotten: The Griswold Case, 64 Micr. L. REv. 235 (1965).

${ }^{306}$ Gregg v. Georgia, 428 U.S. 153, 171-73 (1976) (plurality opinion). 
corded constitutional protection because they are essential to the fulfillment of other express or implied rights. ${ }^{307}$ Occasionally the Court has found textually unarticulated rights to be so fundamental that it has felt no obligation to tie them to the text at all. ${ }^{308}$

To be sure, the Court has resisted pressure to develop and articulate a formula assigning weights or priorities to these nontextual reference points. ${ }^{309}$ But it is crucial to remember that rarely has the Court, or any of its Members, paid blind homage to an absolutely linquistic and literal analysis of the constitutional wording. ${ }^{310}$ The text has served as the touchstone for analysis, from which the Court has discerned the concepts ${ }^{311}$ and values informing its work.

If the Court were to analyze the fifth and fourteenth amendments from an absolute or literal perspective, it would find little textual support for the inherent dignitary values espoused here. Those amendments do not expressly proscribe the infringement of "inherent dignitary values without due process of law"; nor do they prohibit the deprivation of "due process without due process of

307 See, e.g., Carey v. Population Serv. Int'l, 431 U.S. 678 (1977) (right of access to contraceptives essential to exercise of the constitutionally protected right of decision in matters of childbearing). But see Maher v. Roe, 432 U.S. 464 (1977) (upholding a state's denial of medicaid funds for nontherapeutic abortions, after dismissing the argument that state impermissibly interfered with fundamental right of personal choice in childbearing).

308 See, e.g., Shapiro v. Thompson, 394 U.S. 618, 630 (1969) (the right to interstate travel is so fundamental that Court had "no occasion to ascribe the source" of the right to "a particular constitutional provision") (footnote omitted).

309 Especially in the equal protection context, forceful arguments have been advanced in favor of wide methodological latitude in defining constitutional rights and values. See, e.g., Massachusetts Bd. of Retirement v. Murgia, 427 U.S. 307, 317 (1976) (Marshall, J., dissenting). See generally Gunther, Foreword: In Search of Evolving Doctrine On a Changing Court: A Model for a Newer Equal Protection, 86 HaRv. L. REv. I (1972).

310 On the modern Court, Justice Rehnquist has shown perhaps the greatest affinity for a constitutional methodology tightly cabined by rigid positivism. See, e.g., Craig v. Boren, 429 U.S. 190, 217 (1976) (Rehnquist, J., dissenting); Arnett v. Kennedy, 416 U.S. 134 (1974) (plurality opinion); Sugarman v. Dougall, 413 U.S. 634, 649-64 (1973), Rehnquist, J., dissenting). But, as Professor Shapiro has noted, even Justice Rehnquist has occasionally eschewed absolute allegiance to that constitutional faith. Shapiro, supra note 125, at 299-307 (1976).

Similarly, Justice Black's constitutional philosophy was characterized by its pronounced commitment to literalism. See H. BrACK, supra note 299; Black, The Bill of Rights, 35 N.Y.U. L. Rev. 865 (1960). Yet, even "Justice Black's absolutes cannot really be deemed ... absolute absolutes, and . . . they do not emerge as such from the constitutional text .... LEAST DaNGerous Branch, supra note 2, at 93 (citing Charles Black, Mr. Justice Black, the Supreme Court and the Bill of Rights, HARPER's, February, 1961, at 63). See generally id. 85-110.

311 For a useful discussion of the distinction between concepts and conceptions, especially as they relate to the constitutional ideal of fairness, see TAksvc Rrghts SERrousLx, supra note 6 , at 134-37. 
law." 312 On the other hand, neither do those amendments explicitly adopt the Court's approach by inveighing against the deprivation of liberty or property as "defined by existing rules or understandings that stem from an independent source such as state law" 313 and as limited by the procedural guarantees therein provided. ${ }^{314}$ However, in light of the fact that the fifth and fourteenth amendments, along with the entire Bill of Rights, were intended to prescribe limitations on governmental power sufficient to preclude a temporal conception of the public good from negating an underlying measure of individual autonomy, ${ }^{315}$ the inclusion of inherent dignitary values within the due process umbrella adequately comports with legitimate interpretational techniques and constitutional goals. $^{316}$

One further point should be made. The techniques of constitutional interpretation proposed here reflect a non-absolutist view of the relationship between words and ideas. Essentially, this approach rejects the conclusion that the framers intended to have their words denied the meaning necessary to uphold the values they sought to protect. Of course, placing too much distance between clear textual import and ultimate constitutional command can create significant risks both to the Court itself and to the integrity of the values articulated here. But preoccupation with literalism is

312 See Cracks in "The New Property," supra note 69, at 450-52.

313 Board of Regents v. Roth, 408 U.S. 564, 577 (1972). See Meachum v. Fano, 427 U.S. 215, 226 (1976); Bishop v. Wood, 426 U.S. 341, 344 (1976).

314 See Arnett v. Kennedy, 416 U.S. 134, 152 (1974) (plurality opinion).

315 See, e.g., Procedural Due Process, supra note 4, at $1525 \mathrm{n} .68$, and authorities cited therein.

316 In this respect, the extension of due process protection to inherent dignitary values is no less compelled by the text than is the Court's approach, which excludes from the realm of due process all interests not expressly protected by legislative prerogative. Nor is the constitutional protection of dignitary values any less textually supportable than the constitutional right to privacy. See, e.g., Carey v. Population Serv. Int'l, 431 U.S. 678 (1977) (right to obtain contraceptive information and devices); Roe v. Wade, 410 U.S. 113 (1973) (privacy right includes right to obtain abortion); Griswold v. Connecticut, 381 U.S. 479 (1965) (right to obtain contraceptive devices). See also Moore v. City of East Cleveland, 431 U.S. 494 (1977) (right to live with members of extended family); Stanley v. Illinois, 405 U.S. 645 (1972) (right to live with members of nuclear family). In fact, it would not require much expansion of the constitutional right to privacy to bring a general right to freedom from arbitrary governmental action within its purview. Thus, in Whalen v. Roe, 429 U.S. 589 (1977), the Court cited with apparent approval Professor Kurland's view that the constitutional right to privacy includes a general, but as yet largely undefined, "right of the individual to be free in his private affairs from governmental surveillance and intrusion," and "the right ... to be free in action, thought, experience, and belief from governmental compulsion." Id. 599 n.24 (quoting Kurland, The Private I, U. Chr. Magazne 7, 8 (Autumn (1976)). See generally AMmRrcan Constrtutronal LAw, supra note 54, at 889-93. 
largely based upon fears of judicial discretion, ${ }^{\mathbf{3 1 7}}$ of distinctions between law and politics, ${ }^{318}$ and of the underlying dilemma of antimajoritarianism in judicial review. This dilemma, however, itself is unsusceptible to an absolutist resolution. For in a very real sense, judicial review, with all - of its implications for the integrity of the political processes, is a quintessential symbol of democracy. ${ }^{319}$ It manifests and implements an ingredient central to the framers' constitutional scheme: that majoritarian processes left unrestrained will inevitably be abusive to minority interests and will threaten the primacy of fundamental human rights. Of course, judicial power, too, can be abused; moreover, it will often create tension with other equally legitimate and more representative forms of power. But this tension in itself can foster evolution toward basic democratic ideals. ${ }^{320}$

Guided by these perceptions, we must develop conceptual frameworks for constitutional adjudication which account for the greater risk of abuse in judicial power as it becomes less confined by strict textual anchors. In the process, however, we must understand that these abuses, and their remedial counterparts, will occur along a continuum. At one end of the continuum lies a total abdication of judicial responsibility, while at the other lies the total usurpation of

317 Professor Tushnet has characterized that fear in these terms: "A basis in the constitutional text keeps the Court from retreating into chambers and emerging with constitutional decisions full blown from the heads of the Justices." Tushnet, supra note 11 , at 278 .

Tushnet also contends that "[i]f, however, all we require is some sticking point around which the constitutional argument can focus, the words of the Constitution need not be the only candidate; and almost any publicly disclosed standard will do." Id. 279. The "sticking points" he offers for due process analysis include the works of such groups as the American Law Institute and the Commissioners of Uniform State Laws. Id. The basic problem with this approach lies in its implication that objectivity per se is a paramount ingredient for legitimacy in judicial review, regardless of the extent to which the standards for objectivity can be related to the constitutional text, structure, or intent. A substitution of the views of distinguished commissions, technicians, or scholars for those of the Justices risks an expansion or exacerbation of the problems created by discretion in constitutional decisionmaking, without answering the underlying question of constitutional authority.

In this regard, my attempt to argue for a recognition of dignitary values as constitutionally derived relies upon implications drawn from the political philosophy that guided the framers' work, and upon the resultant constitutional structure of limited powers found in the Bill of Rights. See American Constrtutionar. Law, supra note 54 , at 893-98.

318 See, e.g., IDEA of Progress, supra note 6; Kurland, supra note 6. But see M. Shapiro, Law and Potrtics in the Supreme Court (1964).

319 See, e.g., Taknve Rughts Seriousty, supra note 6, at 131-49. See also Heymann \& Barzelay, supra note 6, at 783 n.83.

320 See, e.g., Constitutional Welfare Rights, supra note 24, at 1010-19. See also Chayes, The Role of the Judge in Public Law Litigation, 89 HARv. L. REv. 1281, 1316 (1976). 
political power. To the extent that the Roth-Bishop-Meachum methodology has immunized legislative and administrative action from any independent constitutional restraints, it represents a clear abdication of the Court's primary function. It is for this reason that new procedural due process methodologies, more responsive to inherent dignitary values, are essential if the Court is to fulfill its role as the "formidable bulwark against governmental violation of the constitutional safeguards securing in our free society the legitimate expectations of every person to innate human dignity and sense of worth." 321

\section{B. A Preliminary Response to the Skeptics}

This conceptual framework from which more responsive due process methodologies can be derived is not novel, and has been rehearsed more extensively elsewhere. ${ }^{322}$ As indicated by the RothBishop-Meachum line of cases, however, it does not represent the framework adopted by a majority of the Burger Court. Moreover, support for a methodology flexible enough to extend protection to inherent dignitary values has been qualified, even in the writings of respected constitutional scholars from whom stronger endorsements might have been expected. For example, Professor William Van Alstyne, who has written in support of the liberalization of due process methodology, ${ }^{323}$ now argues that Dixon v. Alabama State Board of Education, ${ }^{324}$ which held that "the State cannot condition the granting of even a privilege [education at a state college] upon the renunciation of the constitutional right to procedural due process," 325 "heedlessly . . . read into the fourteenth amendment a substantive (phantom?) constitutional right to due process." $326 \mathrm{He}$ further suggests that the Fifth Circuit would have acted more appropriately had it "met this difficulty simply by identifying the "matriculation status' of the students as constituting a property right,

321 Paul v. Davis, 424 U.S. 693, 734-35 (1976) (Brennan, J., dissenting).

322 See, e.g., Heymann \& Barzelay, supra note 6; Perry, Abortion, The Public Morals, and the Police Power: The Ethical Function of Substantive Due Process, 23 U.C.L.A. L. Rev. 689, 707-22 (1976); Rostow, supra note 6; Wright, The Role of the Supreme Court in a Democratic Society-Judicial Activism or Restraint?, 54 CoRNEL. L. REv. I (1968).

323 Demise of Right-Privilege Distinction, supra note 68.

324294 F.2d 150 (5th Cir.), cert. denied, 368 U.S. 930 (1961) cited with approval in Goldberg v. Kelly, 397 U.S. 254, 262-63 n.9 (1970).

325294 F.2d at 156 (emphasis added).

326 Cracks in "The New Property," supra note 69, at 452. 
not subject to deprivation without (procedural) due process of law." 327

Similarly, Professor Michelman, whose apparent concern for guarding against arbitrary and unjust governmental action (and inaction) has been eloquently expressed elsewhere, ${ }^{328}$ has suggested that nonformal (i.e., inherent dignitary) values "are fuzzy notions nowhere explicitly recognized in the Constitution, so that to found a due process doctrine upon them would smack of judicial creativity or 'activism." "329 Moreover, he describes circumstances in which the courts, "prompted by nonformal sympathizing with demands for revelation and participation," ${ }^{330}$ have arguably created "fake entitlements" of procedural rights by tying such rights to more positivistic (and therefore more legitimate) entitlement sources. ${ }^{331}$ Ultimately, Michelman concludes that:

If such a thing as a right to nonformalistic due process is conceivable, it must be a right of a sort of which we (or I) do not now have an adequate idea, a right existing outside the formalistic-positivistic framework, a claim or drive or value having a mandatory quality, yes, but not ultimately dependent upon judicial coercion because grounded in shared values. ${ }^{332}$

Accordingly, Michelman suggests that a "back-door" approach to due process protection of inherent values may be the most we can demand, or at least the most we can now hope for. ${ }^{333}$

327 Id. 455 (citation omitted) (parenthetical in original). Professor Van Alstyne does, however, argue later that the Court might properly "treat freedom from arbitrary adjudicative procedure as a substantive element of one's liberty . . . ." Id. 487 (emphasis in original). Although the first methodological alternative to Roth-Bishop-Meachum, discussed in text accompanying notes 145-64 supra, is basically the same as Van Alstyne's, his concern seems primarily directed toward protection of what I have previously described as substantive dignitary values. See note 133 supra.

For another recent discussion questioning whether the definition of liberty should be expanded to encompass the dignitary values discussed in this Article, see Monaghan, supra note 71, at 414-16.

328 See Constitutional Welfare Rights, supra note 24, at 1003-19; Foreword: On Protecting the Poor, supra note 34.

329 Formal and Associational Aims, supra note 35, at 132-33.

Professor Michelman has also suggested that concerns for a "commitment on the Court's part to a modest judicial role" have caused courts which might otherwise be responsive to reading "the due process guaranty to require officials to offer explanatory procedures to individuals exposed to harm by official actions" to create a more positivistic methodology to achieve that result. Id.

$330 \mathrm{Id} .145$.

331 Id. $145-48$.

332 Id. 149-50 (footnote omitted) (emphasis in original).

333 Id. 152-53. Professor Michelman's conclusions seem to derive largely from his view that "nonformal aims of explanatory procedures resist effective enforcement 
The "fake entitlement" analysis described by Professor Michelman and implicitly advanced by Professor Van Alstyne, however, reflects a troublesome lack of candor in the judicial process, and does so quite unnecessarily. As I have suggested, methodologies extending the Roth-Bishop-Meachum liberty analysis or recognizing an independent right to procedural due process are fully consistent with concerns for judicial modesty and are compatible with processes of constitutional analysis recognized as legitimate in other contexts. Moreover, assuming that there are no absolute resolutions to the dilemma of the judicial role in constitutional review, one can reject an analysis which forecloses protection of inherent dignitary values in favor of one which does not, at least when the Constitution does not expressly compel or preclude either.

in the guise of rights in a formal legal order . . . "Id. 150. Moreover, he expresses concern that an attempt to enshrine in the Constitution a right to participation and revelation may be counter-productive, because when the reasons for deprivatory governmental action are "supplied under threat of legal retribution," they may not satisfy "the internal need for revelation." Id. His point is premised, in part, upon a view that the goal of inherent due process values is defined solely in terms of providing the individual "authentic, honest communication of the truth concerning the image others hold of him ...." Id. In my view, this definition is incomplete. As I have suggested, see notes 32-59 supra, inherent values also include assurances that one is being treated as an end in herself, and that governmental actors and institutions must be held accountable for respecting one's individuality, even if the process of accounting reveals the darker side of life in the mass administrative state.

Ideally, of course, authentic and honest communication of the truth concerning how one is perceived by one's government is desirable. It is possible, however, that constitutionally required and judicially imposed opportunities for participation and revelation will not always be enthusiastically and sincerely provided by government officials. The process may, instead, reveal a callous indifference or even contempt in which the individual is actually held by the official involved. Even if such is the case, the episode serves some purpose, because it reveals to the individual the true nature of her relationship with at least that official or institution. The individual in this situation could be viewed as better off for having this knowledge, because decisions concerning her general views of political or legal obligation would be better informed. Moreover, under a regime in which there is at least an opportunity for participation and revelation, there would be a greater likelihood of engendering the belief that government, in a sense broader than one official or institution, is concerned enough to be honest with its citizens.

There is one further reason for questioning Professor Michelman's premise. It seems at best implausible that governmental officials acting responsibly and in good faith will precipitously abandon these traits merely because of a requirement that deprivatory decisions be justified and explained to the individuals affected. It is equally plausible, if not more likely, that they will react in the opposite fashion. Thus, an official cognizant of the negative impact that a decision is likely to have, and sensitive to the affected individuals' innate dignity, might be eager for an opportunity to explain or justify deprivatory action and perhaps to "soften the blow." Moreover, to the extent that the official has discretion in reaching or enforcing a decision, the opportunity to face the individual affected may trigger such discretion in a benign manner. But see Dixon v. Love, 431 U.S. 105, 114 (1977), in which the plaintiff sought precisely this opportunity to appeal to the benign discretion of a government official, but ultimately was denied it. 


\section{Inherent Dignitary Values, Consent, and the Judicial Role:} Some Final Comments From a Bickelian Perspective

There is one further response to the charge that the alternative model of procedural due process presented here would entail "judicial immodesty" sufficient to render it illegitimate. This response is premised upon the belief that inherent dignitary values constitute a necessary element of the consent which is essential to the continuing viability of a just and morally supportable constitutional government. It is further premised upon a view of the relative capacities of our legislative, executive, and judicial institutions to preserve the conditions necessary for such consent.

\section{The Bickelian Concept of Judicial Review}

The roots for the view advanced in this section are to be found in the writings of the late Professor Alexander Bickel. In two of his most insightful books, The Least Dangerous Branch ${ }^{334}$ and The Morality of Consent, ${ }^{335}$ Bickel provided a framework for the analysis of the judicial power of constitutional review which focused on the tensions inherent in the exercise of that power. At the core of his theory was a perception that the first purpose and obligation of the legal order in a democracy is the maintenance of stability, which is a condition precedent to society's ability to fulfill its underlying moral and ethical commitments. ${ }^{336}$ Essential to stability is the government's ability to acquire and retain a popular perception of legitimacy, which is defined in terms of the extent to which government is responsive to the commands and needs of the governed." To Bickel, "[l] egitimacy, being the stability of a good government over time, is the fruit of consent to specific actions or to the authority to act ...." 338 Moreover, "central to the process of gaining the consent of the governed" is the proposition "that the majority has the ultimate power to displace the decisionmakers and to reject any part of their policy." 339 Without such consent, a gov-

334 Least Dangerous Brance, supta note 2.

335 A. Bickex, The Moraltty of Consent (1975) [hereinafter cited as Moratity of Consent].

330 See id. 120 ("But our legal order cannot endure too rapid a pace of change in moral conceptions, and its fundamental premise is that its own stability is itself a high moral value, in most circumstances the highest."). See also id. 15.

337 Id. 29; Least Dangerous Branch, supta note 2, at 29.

338 Id. 30.

339 Id. 27.

Of consent, Bickel also said: "What is above all important is consent-not a presumed theoretical consent but a continuous actual one, born of continual responsiveness." MORAIITY OF CONSENT, supra note 335, at 100. See also LEAST 
ernment can no longer be perceived as morally justified or supportable: when this happens, instability becomes inevitable, ${ }^{340}$ accompanied by the maintenance of power through raw coercion.

In Bickel's scheme, consent is central to the stability and viability of a morally supportable, democratic government. It therefore is incumbent upon a government to function in ways that promote and preserve conditions necessary for consent. Governmental policies or institutions that threaten those conditions must be regarded as suspect. Against this background of the interrelationships between responsiveness, legitimacy, and consent, the dilemma of the judicial role, and particularly that of the Supreme Court, arises. Because the federal judiciary is the least popularly responsive and representative branch of government, ${ }^{341}$ judicial review must be regarded as "a counter-majoritarian force in our system," ${ }^{442}$ and a "deviant institution in American democracy." 349 To the extent that the federal judiciary is less responsive to popular pressure than are the legislative and executive branches, judicial review of legislative and executive policies becomes threatening to the values of consent and stability. On the other hand, Bickel did not suggest that the exercise of judicial power was always illegitimate, for a morally supportable government must serve not only the immediate needs of the governed, but must also preserve and develop "certain enduring values." 344 Insulated from the

Dangerous Branch supra note 2, at 20 ("[C]oherent, stable-and morally supportable-government is possible only on the basis of consent, and ... the secret of consent is the sense of common venture fostered by institutions that reflect and represent us and that we can call to account." (emphasis in original)).

340 For Bickel, instability might initially be manifested by civil disobedience, which might at first have the effect of helping to promote consent and stability. But, ultimately, civil disobedience "is attended by the overhanging threat of anarchy," MoRalrTy of Consent, supra note 335, at 119 . Premised upon deeply held and intensely principled opposition to the legal order, civil disobedience leads to a condition in which "effective enforcement [of law] is possible, if at all, only through military occupation." Id. 108.

For further discussion of the relationships between disobedience and anarchy, see R. WolfF, In Defense of ANarchy (1970).

341 See generally, LEAST DANGERous Branch, supra note 2, at 16-23.

342 Id. 16.

343 Id. 18.

344 The point of departure is a truism; perhaps it even rises to the unassailability of a platitude. It is that many actions of government have two aspects: their immediate, necessarily intended, practical effects, and their perhaps unintended or unappreciated bearing on values we hold to have more general and permanent interest. It is a premise we deduce not merely from the fact of a written constitution but from the history of the race, and ultimately as a moral judgment of the good society, that government should serve not only what we conceive from time to time to be our immediate material needs but also certain enduring values. This in part is what is meant by government under law. But such values do not 
storms of politics, the judiciary is better equipped and prepared to respond to, protect, and preserve these values. ${ }^{345}$ Even in performing this essential task, however, the judiciary must act cautiously, always mindful that its power is presumptively deviant. ${ }^{346}$ Guided by these cautions, however, the exercise of judicial power can achieve "a tolerable accommodation with the theory and practice of democracy." 347

In this Bickelian view of judicial power, the Supreme Court's function, although circumscribed, is not rendered sterile or meaningless. The Court retains the power to invalidate or uphold legislative and executive policies or practices on the basis of its assessment of their congruence with fundamental principles of fairness and justice expressed in, or symbolized by, the Constitution. In attempting to define these constitutional principles, the "text can serve only as the putative starting point ... not as both its certain beginning and its unequivocal end." 348 For the most part, Bickel did not attempt to identify those specific constitutional values which he considered important enough to require judicial vindication, even at the expense of other values embodied in legislative

present themselves ready-made. They have a past always, to be sure, but they must be continually derived, enunciated, and seen in relevant application. And it remains to ask which institution of our government-if any single one in particular-should be the pronouncer and guardian of such values.

Id. 24.

\section{Id. 25-26.}

346 See id. 27: "But democracies do live by the idea, central to the process of gaining the consent of the governed, that the majority has the ultimate power to displace the decision-makers and to reject any part of their policy. With that idea, judicial review must achieve some measure of consonance."

In this regard, Bickel also observed:

The Court, an independent body of men, not responsible or responsive after the fashion of democratic institutions but answerable only, as Chief Justice Warren pointed out in his farewell remarks, each to his conscience, is not only an effective instrument for ensuring fairness and justice in the government's dealings with the individual, but a splendid instrument for forcing the society's attention to issues of principle, particularly issues of moral principle that often are submerged in the welter of affairs. When such a body of men goes farther, not merely to expose issues of principle but to impose its own resolutions of them, the consequences may again be beneficial. Of that, posterity is the judge. But contemporaneous doubts are rooted in the democratic faith, which holds that the society at large ought to participate in the venture of governing itself, and that the general good is achieved by pragmatic trial and error-having regard to principle, but not dogmatically bound to it in action-which is the genius of democratic institutions.

Morality of Consent, supta note 335 , at 105.

347 Least Dangerous Branch, supta note 2, at 28.

348 Id. 74 . 
or executive acts. The most he could offer in this respect was the following view:

Our point of departure . . . has been that judicial review is the principled process of enunciating and applying certain enduring values of our society. These values must, of course, have general significance and even-handed application .... For, again, the root idea is that the process is justified only if it injects into representative government something that is not already there; and that is principle, standards of action that derive their worth from a long view of society's spiritual as well as material needs and that command adherence whether or not the immediate outcome is expedient or agreeable. ${ }^{349}$

It might be said that this advice is of little help to a Court sensitive to its origins and its frailties. But considering the vagueness of the important, value-laden constitutional provisions, perhaps it is all that we can expect or demand. In any event, Bickel did leave us with the view that although the Court should do more than act to ensure "the successful operation of the venture at hand," 350 it must do at least that. To the extent that the maintenance of the fabric of consent is essential to the fulfillment of other fundamental values, the Court is obliged to act in preservation of consent; indeed, such action is even more crucial in those situations in which the other branches of government have either failed to preserve consent, or have actively undermined it.

\section{Inherent Dignitary Values and Consent}

Professor Bickel's conceptual framework for judicial review represents an important attempt to balance constitutionally manifested values of fairness and justice with the equally compelling and sometimes competitive value of consent. This framework purported to reject the view that concerns for legitimacy require effective abdication of judicial power, in favor of a view that these concerns require deliberate and perhaps selective use of such power-what Bickel described as judicial power "at retail." 351 Although Bickel could disagree with the extent to which that power should be used, ${ }^{352}$ and earn, from some quarters, the reputation as an exponent 
of a "conservative ideology," ${ }^{353}$ his writings portray the Court as the ultimate safety valve in a system whose other internal fail-safe devices are imperfect.

Within this framework, the recognition and protection of inherent dignitary values can be viewed as not only a legitimate, but an essential exercise of judicial power. In a fundamental way, these values are central to concepts of moral, legal, and political obligation, which are the barometers of consent. ${ }^{354}$ When moral obligation exists-when people feel obliged to comply with law because the law is morally right-consent and stability naturally follow. When that sense of obligation is absent, however, people will obey the law and subject themselves to governmental power for other reasons, such as fear of legal sanctions. Another reason for obedience might be a general willingness to accept the consequences of collective judgments, emanating from a view that the legal order as a whole is just and that occasional sacrifice of individualism to collectivism is essential for the eventual enhancement of individualism..$^{355}$ In several ways, these latter two rationales for obligation

353 See, e.g., Wright, supra note 6, at 796.

354 Although an in-depth analysis of the distinctions between these various concepts of obligation is beyond the scope of this article, the following points should be made here. Notwithstanding the ongoing debate in moral and political philosophy with respect to the existence of a prima facie obligation to obey the law, compare, Smith, Is There a Prima Facie Obligation to Obey the Law?, 82 YALE L.J. 950 (1973), with J. RawLs, supra note 24, at 333-42 and H. Prichand, Green's Principles of Political Obligation, in Moral OBLIGatron 54 (1949), there seems to be widespread agreement that obligation has many forms, each of which has important implications for the viability of a morally supportable legal order. See generally Gewirth, Obligation: Political, Legal and Moral, in Pourricar AND Legar Obligatron: Nomos XII 55 (J. Pennock \& J. Chapman eds. 1970); Ladd, Legal and Moral Obligation, in Poltricar and Legal ObLigation: Nomos XII 3 (J. Pennock \& J. Chapman eds. 1970). Put crudely, a distinction between moral obligation, on the one hand, and political and legal obligation on the other, might be comparable to the difference between feeling obligated to do what the government (or a constitution) requires, and being obligated to do so. See, e.g., MacCallum, On Feeling Obligated to Do What a Constitution Requires, in Polmtical and Legat Obltgation: Nomos XII 214 (J. Pennock \& J. Chapman eds. 1970). The same general idea is often discussed in terms of the distinctions between being "obliged" and being "obligated." See, e.g., Baker, supra note 177, at 49-50. Ideally, a just and morally supportable legal order is one in which every member feels morally obligated to legal obedience, so that people comply with governmental directives because they believe that compliance is right. In such an order, consent would be complete and inevitable. However, such an absolute form of moral obligation belies human experience, and may even undermine democratic values of individualism. Consequently, political and legal obligation, defined as obedience to government despite the absence of a belief that obedience is right, are often viewed as the more pragmatic conditions for a stable legal order. See also Nagel, Causes and Effects of Constitutional Compliance, in Polrtical AND LEgaL Obligatron: Nomos XII 219 (J. Pennock \& J. Chapman eds. 1970). A legal order in which moral obligation is generally absent would be in constant peril of disequilibrium or instability.

${ }^{355}$ See J. RAwLS, supra note 24, at 114-17. 
provide significantly less secure bases upon which to strengthen and preserve consent and stability than does that of moral obligation. First, in a society that is not perceived as just by all of its members, the point at which formal sanctions will no longer be considered sufficient reason for continued obligation may be quickly reached. Second, when the potential benefits of obedience to law are viewed as too remote, abstract, or illusory, the tradeoffs between the collective "now" and the enhanced individualism of tomorrow may be viewed as unacceptable. In either situation, obligation will give way to raw coercion, and coercion to instability.

It is in this respect that protection of inherent dignitary values will tend to generate at least the weaker forms of obligation and thus preserve minimal conditions necessary for consent. If a sense of moral obligation does not attach to deprivatory governmental action, the degree of political or legal obligation engendered may very well depend upon the processes through which the underlying decision is made and implemented. ${ }^{350}$ In other words, an individual's willingness ultimately to be subjected to deprivatory governmental action may be directly related to the extent to which the decisionmaking process generates "the feeling, so important to a popular government, that justice has been done." 357 Moreover, in a cumulative sense, the impressions left by any one action are likely to color the individual's perception toward other deprivatory actions; thus, each action substantially affects the integrity and vitality not only of the acting institution, but also of government as a whole. According the individual the opportunity to participate in the decisionmaking process-to face the decisionmaker, to receive ex-

356 It might be argued that the point at which legal and political obligation attach-indeed the point at which moral obligation occurs-is likely to vary substantially between different individuals or groups, and may be a function of the frequency with which deprivatory action occurs and the extent of the deprivation experienced. Accordingly, a poor person, perhaps completely dependent upon government largess and with little sense of a vested interest in society, is likely to both feel and be less obligated to the exercise of deprivatory governmental power, no matter what form it takes, than is a richer person who has a sense of a greater stake in the society. Moreover, the frequency of deprivatory action directed at the poor is likely to undermine whatever sense of obligation they may feel.

If the point is that deprivatory action detrimental to dignitary values does not threaten society's stability, because it only impacts upon those who already feel little sense of obligation, this argument is unpersuasive in at least two respects. First, non-poor persons can be rendered impoverished through deprivatory action. See, e.g., Bishop v. Wood, 426 U.S. 341 (1976); Mathews v. Eldridge, 424 U.S. 319 (1976). Thus, even persons with more substantial stakes in the status quo may ultimately perceive continued arbitrary governmental action as unjust. Second, and perhaps more importantly, an unobligated and disaffected minority can precipitate instability and even anarchy.

357 Joint Anti-Fascist Refugee Comm. v. McGrath, 341 U.S. 123, 172 (1951) (Frankfurter, J., concurring) (footnote omitted). 
planation and revelation, and to react orally-preserves and enhances her sense of personal dignity and individual autonomy, and thereby strengthens the prospects for future obligation and consent. This much Bickel himself implicitly recognized, when he wrote: "Consent will not long be yielded to faceless officials, or to mere servants of one man, who themselves have no 'connexion with the interest of the people." "35s The Court's failure to recognize that coercive governmental action implicates inherent dignitary values, and its concomitant failure to protect those values by instituting appropriate procedural protections, is extremely anomalous. ${ }^{359}$ Through

358 Monatity of Consent, supta note 335, at 18.

350 Sensitivity to the centrality of human dignity and autonomy in our democratic tradition has led the Court to impose procedural restraints on the exercise of arbitrary governmental power in a host of other areas. In perhaps the most prominent example, the Court held in Woodson v. North Carolina, 428 U.S. 280, 303-05 (1976) (plurality opinion), that the constitutionality of capital punishment is predicated upon, inter alia, the availability of a "particularized consideration of relevant aspects of the character and record of each convicted defendant before the imposition upon him of a sentence of death." Id. 303. This requirement was compelled because, in its absence, the state would be treating "all persons convicted of a designated offense not as uniquely individual human beings, but as members of a faceless, undifferentiated mass ...." Id. 304. Such a denial of individuality was held violative of the eighth and fourteenth amendments. See also Gregg v. Georgia, 428 U.S. 153 (1976) (plurality opinion).

Moreover, in other areas of criminal law, when something less than the ultimate deprivation was involved, the Court has imposed other substantial restraints upon the government's power to structure criminal justice processes, because of the omnipresent danger that unbridled power poses to human dignity. In Miranda v. Arizona, 384 U.S. 436 (1966), for example, the Court recognized that the interrogation atmosphere was potentially "destructive of human dignity," id. 457. Moreover, the Court noted that the fifth amendment's privilege against compulsory self-incrimination was premised upon "the respect a government-state or federalmust accord to the dignity and integrity of its citizens." Id. 460. One thoughtful commentator has noted: "The Miranda Court's usage of rights implies that the government must act in a way that respects the individual's full and equal membership in the community, that it must act in a way consistent with his dignity." Baker, supra note 177 , at 53 n.46.

Similarly, first amendment rights to freedom of expression have been accorded strong constitutional protection because of their essential role in assuring the potential for individual self-fulfillment. See, e.g., T. EMIERSon, TrE SYSTEMr of Freedom of Expression 6 (1970). By guaranteeing the opportunity for participation in societal decisionmaking, the first amendment has been viewed as instrumental to the generation of feelings of self-respect and integrity inherent in personal dignity and full membership in the community. See e.g., Whitney v. California, 274 U.S. 357, 372 (1927) (Brandeis, J., concurring). Moreover, the free, open, and robust exchange of ideas encouraged by the first amendment fosters feelings of obligation and consent, thus ensuring that governmental institutions and policies can be changed in an evolutionary and peaceful manner. See generally MoratrTy of Consent, supra note 335, at 57-88; T. EMerson, supra. See also Lusky, supra note 21.

Furthermore, the constitutional right to privacy has been derived from and informed by concepts of personal dignity and autonomy. See, e.g., Zablocki v. Redhail, 434 U.S. 374 (1978); Whalen v. Roe, 429 U.S. 589 (1977); Olmstead v. 
these failures the Court not only ignores the fundamental importance of human dignity in our democratic tradition, but perhaps more crucially permits the continuing erosion of those bases upon which a just, stable, and viable government depends.

\section{CONCLUSION}

In its recent attempts to define the range of procedural protection mandated by due process, the Supreme Court has developed a methodology that appears to be incapable of responding to values of human dignity. These values have been central to the construction and development of democratic political theory, and have been of fundamental importance in the evolution of American constitutionalism. They embrace both substantive and inherent aspects, respectively focusing upon outcomes and processes associated with government-individual interaction. In the major cases defining its approach to due process, ${ }^{360}$ the Court has expressed almost exclusive concern for the impact of coercive, deprivatory governmental action upon substantive values. Accordingly, analysis has centered on the form and substantive content of various kinds of governmental largess. When the legislative description of largess has not stipulated conditions upon which an entitlement can be terminated or modified, or has omitted procedures by which any express conditions must be determined, the Court has held that conditions or procedures cannot be constitutionally imposed; that is, that due process does not attach. This view has essentially left unrestrained the legislative power to determine the extent to which

United States, 277 U.S. 438, 478 (1928) (Brandeis, J., dissenting). See generally AMERICAN Constitutional LAw, supra note 54, at 886-990.

Finally, in addressing the right of a person to protect his reputation, Mr. Justice Stewart recognized that it is essential that the government maintain an abiding concern for the dignity and integrity of individuals:

[O]ur basic concept of the essential dignity and worth of every human being [is] a concept at the root of any decent system of ordered liberty. The protection of private personality, like the protection of life itself, is left primarily to the individual States under the Ninth and Tenth Amendments. But this does not mean that the right is entitled to any less recognition by this Court as a basic of our constitutional system.

Rosenblatt v. Baer, 383 U.S. 75, 92 (1966) (Stewart, J., concurring). See also Gertz v. Robert Welch, Inc., 418 U.S. 323,341 (1974).

In all of these various contexts, the Court has been guided by a fundamental respect for the dignity of human beings. I can see no basis for denying these values in the context of civil, deprivatory governmental action. To ignore their existence and importance in defining the procedural protections of due process contradicts the role that concern for human dignity has played in the development of our constitutional jurisprudence.

360 Meachum v. Fano, 427 U.S. 215 (1976); Bishop v. Wood, 426 U.S. 341 (1976); Board of Regents v. Roth, 408 U,S. 564 (1972). 
claims to largess attach, change, or disappear. This is true even when the legislative judgment inflicts serious material and psychic deprivations upon individuals either holding or claiming entitlements.

Although due process has generally been held to impose a standard of fairness on the coercive exercise of governmental power, the Court's methodology in many situations denies due process any role at all. In this paradoxical sense, the Court's approach manifests its own standard of fairness. In cases such as Bishop $v$. Wood, ${ }^{361}$ the Court has essentially concluded that an individual's right to fairness cannot achieve constitutional status if it would operate to assert a claim against government for more than the government has given. ${ }^{362}$ This focus, however, is wholly substantive; regardless of the stage in the analysis at which due process attaches, this approach entirely ignores or misconceives the dual nature of fairness as dignity. It legitimates absolute governmental power to establish the rules of access to largess. ${ }^{363}$ Moreover, it overlooks the fact that the creation and distribution of largess inevitably serves as the justification for governmental regulation of, and intrusion into, personal freedoms that would otherwise be beyond the government's legitimate concern. ${ }^{384}$ Finally, and most importantly, it does not account for the prospect that such extraordinary power can be used, whether malevolently or in good faith, to mold the thoughts and behavior of the recipients of largess in ways that negate their individuality. It is this value of individuality-of respect for personal integrity and identity-that forms the core of inherent dignity. To ignore or deny its existence, or discard its importance in the procedural due process equation, ${ }^{365}$ is to invite a regime hostile to the role of the individual under the rule of law.

This Article has suggested two alternative methodologies that the Court could adopt in order to afford constitutional protection to inherent dignitary values. Moreover, a specific model, designed

361426 U.S. 341 (1976).

362 See Cracks in "The New Property," supra note 69, at 460-64, 467-70.

303 That power would, of course, be restricted by substantive constitutional guarantees. See notes 86 \& 128 supra \& accompanying text.

364 See, e.g., King v. Smith, 392 U.S. 309 (1968) (invalidating Alabama welfare regulations denying Aid to Families with Dependent Children to otherwise eligible families where a "substitute father" resided in the home). See also Wyman v. James, 400 U.S. 309 (1971) (home visitation provided for by New York law in connection with Aid to Families with Dependent Children does not violate the fourth or fourteenth amendments). See generally, Note, Rehabilitation, Investigation and the Welfare Home Visit, 79 YALE L.J. 746 (1970); Wright, Poverty, Minorities, and Respect for Law, 1970 DukE L.J. 425.

305 See Dixon v. Love, 431 U.S. 105, 114 (1976). 
to promote participation and personal interaction in the decisionmaking process, was also presented. In light of these alternatives, it is difficult to understand why the Court has developed such a highly positivistic model of procedural due process. The changing composition of the Court itself does not adequately explain its failure to protect dignitary values; for although the Burger Court may have shown itself less responsive to asserted individual constitutional rights than the Warren Court before it, there have not yet been clear signs of a wholesale retrenchment. ${ }^{386}$ Nor does the explanation lie in ignorance; the Court could not fail to understand the implications of its decisions, given the forcefulness and passion of the dissenters. ${ }^{367}$ It is, of course, possible that the Court has for so long failed to perceive due process fairness as bi-faceted that it simply does not find it comfortable to do so now; but this, too, seems an unlikely possibility.

The most credible explanation is that a majority of the Justices, striving to extricate the Court from the activism of the past two decades, may be searching for a methodology that will reduce its involvement in the more political processes of the legislative arena. If this is true, and the Roth-Bishop-Meachum approach is born of concerns for judicial restraint, then it is worth noting that this approach is no more constitutionally compelled than are the alternatives suggested here. The difference is that the Court's approach has a severely deleterious impact upon the individual and at least suggests dangerous implications for the viability of constitutionalism as we know it.

To be sure, the alternative approaches advanced here are themselves not expressly compelled by the constitutional text. But even a Court extremely sensitive to its institutional limitations and conscious of the stigma of illegitimacy often associated with the exercise of judicial power should not be reluctant to recognize and enforce inherent dignitary values. A less positivistic, more flexible methodology of procedural due process is not only consistent with, but even mandated by, a modest judicial role. Although due process can be properly viewed as a moral command, ${ }^{308}$ its meaning need not depend upon the particular moral philosophy of a particular judge. Instead, the values that define individual dignity may be

366 See, e.g., Trimble v. Gordon, 430 U.S. 762 (1977); Brewer v. Williams, 430 U.S. 387 (1977).

367 See, e.g., Meachum v. Fano, 427 U.S. 215, 229 (1976) (Stevens, J., dissenting); Bishop v. Wood, 426 U.S. 341, 350 (1976) (Brennan, J., dissenting).

368 See, e.g., Kadish, supra note 1, at 341 . 
found in a constitution, even when that document is viewed not as a mandate for a particular moral vision, but as a framework of structures and processes. ${ }^{369}$ Within this framework, progress need not be measured solely in terms of morally desirable results; it can be perceived as the maintenance of stability in periods of flux, thus allowing for resolution of tensions between traditional values and contemporary realities. In this sense, the Court's recognition of the fundamental relationship between individual dignity and stability, and its development of a procedural due process methodology flexible enough to confirm and nurture values of personal integrity, autonomy, and self-respect, would be consistent with the highest tradition of judicial modesty and restraint. The concomitant facilitation of a more just social order can be treated, if it must, as an incidental benefit.

309 See Morantry of Consent, supta note 335 , at 29 . See also Tribe, From Environmental Foundations to Constitutional Structures: Learning from Nature's Future, 84 YALE L.J. 545, 556 (1975). 